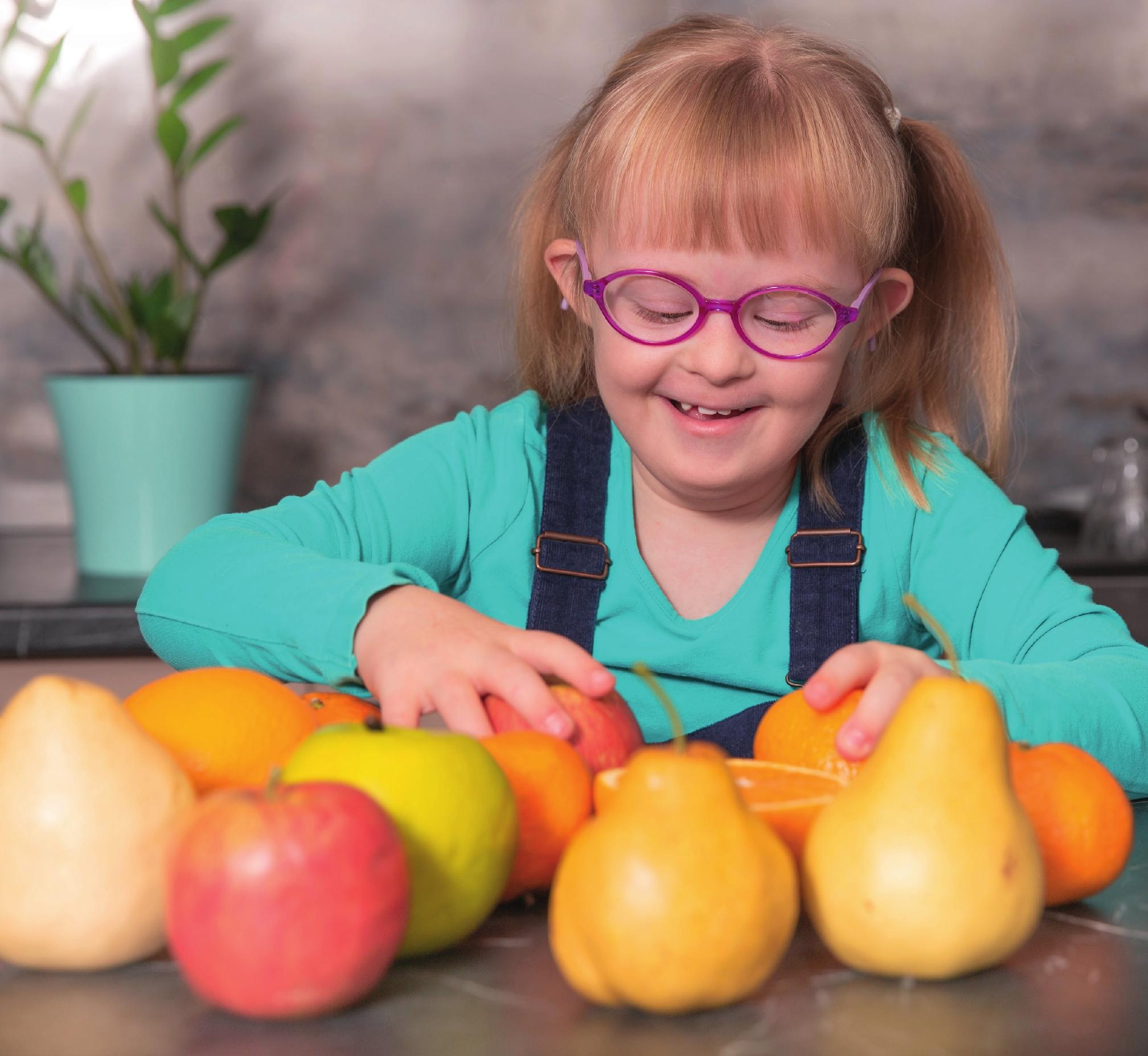

Dietary supplements for children with Down syndrome: exploration of current use and scientific evidence

Fieldwork and literature study

Sandra van der Haar and Gertrude G. Zeinstra 



\section{Dietary supplements for children with Down syndrome: exploration of current use and scientific evidence}

Fieldwork and literature study

Authors: Sandra van der Haar and Gertrude G. Zeinstra

Institute: Wageningen Food \& Biobased Research

This study was carried out by Wageningen Food \& Biobased Research (WFBR), commissioned by the Dutch Down Syndrome Foundation ("Stichting Downsyndroom") and funded by the Wageningen University \& Research Science Shop

Wageningen Food \& Biobased Research

Wageningen, October 2021

Public

Report 376

ISBN 978-94-6395-005-3 


\section{Colofon}

Keywords

Commissioner

Project execution

WFBR project number

Project coordination

Funded by

Version

Approved by

Reviewed by

Supervisory committee
Down syndrome, children, dietary supplements, nutrition, health

Dutch Down Syndrome Foundation ('Stichting Downsyndroom', SDS)

Sandra van der Haar, Gertrude Zeinstra (WFBR)

With support from Wageningen University students:

Arianne Aanstoot, Petra Dijkstra, Heleen van der Hout, Lisanne Renting, Lieke Verlind, Laura van Wijngaarden, Sanne van Wijk and Milou van de Beek

6236202100

Sandra van der Haar

Wageningen University \& Research Science Shop

Final

Annelies Dijk, group head WFBR

Nicole de Wit, expertiseleader WFBR

Gert de Graaf - Scientific officer, SDS

Sandra van der Haar - Nutrition Scientist, WUR

Trea Harperink-Oude Nijhuis - Dietician VG, De Twentse Zorgcentra Michel Weijerman - Physician specialized in Down syndrome, Alrijne Renger Witkamp - Professor in Nutritional Biology, WUR

Martine van der Mast - Programme manager Nutrition \& Health, WUR Gerard Straver - Coordinator Science Shop, WUR

The research that is documented in this report was conducted in an objective way by researchers who act impartial with respect to the client(s) and sponsor(s). This report can be downloaded for free at https://www.wur.nl/nl/show/Voedingssupplementen-bij-kinderen-met-Downsyndroom.htm or at https://doi.org/10.18174/554328 / www.wur.eu/wfbr (under publications).

(C) 2021 Wageningen Food \& Biobased Research, institute within the legal entity Stichting Wageningen Research.

The client is entitled to disclose this report in full and make it available to third parties for review. Without prior written consent from Wageningen Food \& Biobased Research, it is not permitted to: a. use this report for the purposes of making claims, conducting legal procedures, for (negative) publicity, and for recruitment in a more general sense;

b. use the name of Wageningen Food \& Biobased Research in a different sense than as the author of this report.

PO box 17, 6700 AA Wageningen, The Netherlands, T + 31 (0)317 4800 84, E info.wfbr@wur.nl, www.wur.eu/wfbr.

All rights reserved. No part of this publication may be reproduced, stored in a retrieval system of any nature, or transmitted, in any form or by any means, electronic, mechanical, photocopying, recording or otherwise, without the prior permission of the publisher. The publisher does not accept any liability for inaccuracies in this report. 


\section{Contents}

$\begin{array}{ll}\text { Preface } & 5\end{array}$

Summary $\quad 6$

$\begin{array}{lc}\text { List of definitions and abbreviations } & 8\end{array}$

1 Introduction $\quad 9$

$\begin{array}{llr}1.1 & \text { Background } & 9\end{array}$

1.1.1 Introduction to Down syndrome $\quad 9$

1.1.2 Nutrition-related health problems in children with Down syndrome $\quad 10$

1.1.3 Dietary supplements in children with Down syndrome 11

$\begin{array}{lll}1.2 & \text { Objective and research questions } & 12\end{array}$

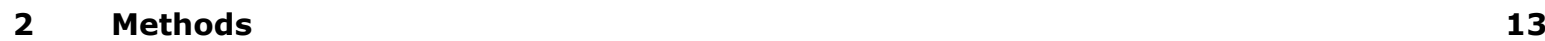

$\begin{array}{llr}2.1 & \text { Fieldwork } & 13\end{array}$

2.1.1 Survey among parents $\quad 13$

2.1.2 Interviews with parents and professionals $\quad 14$

$\begin{array}{ll}2.1 .3 & \text { Inventory of dietary supplements }\end{array}$

2.1.4 Data analyses $\quad 14$

$\begin{array}{ll}2.2 & \text { Literature study } \\ \end{array}$

$\begin{array}{llr}3 & \text { Results } & 17\end{array}$

$\begin{array}{llr}3.1 & \text { Fieldwork } & 17\end{array}$

$\begin{array}{lll}3.1 .1 & \text { Survey results } & 17\end{array}$

$\begin{array}{ll}3.1 .2 & \text { Additional analyses online survey }\end{array}$

$\begin{array}{lll}3.1 .3 & \text { Interviews } & 22\end{array}$

3.1.3.1 Results interviews with parents $\quad 23$

3.1.3.2 Results interviews with experts $\quad 23$

3.1.3.3 Similarities and differences in parents' and experts' viewpoints $\quad 24$

$\begin{array}{ll}3.1 .4 & \text { Inventory of dietary supplements }\end{array}$

$\begin{array}{ll}3.2 & \text { Literature study } \\ & 3.2 .17\end{array}$

3.2.1 Nutritional deficiencies in children with DS 28

$\begin{array}{ll}3.2 .1 .1 \text { Zinc } & 28\end{array}$

3.2.1.2 Vitamin D 28

$\begin{array}{ll}3.2 .1 .3 \text { Vitamin A } & 29\end{array}$

$\begin{array}{ll}3.2 .1 .4 \text { Iron } & 29\end{array}$

3.2.1.5 Folic acid and vitamin B12 29

3.2.1.6 Other minerals $\quad 30$

3.2.1.7 DS comorbidities and possible food-drug interactions 30

3.2.2 Scientific evidence for beneficial effects of dietary supplements in DS 30

3.2.2.1 Evidence from review papers 31

3.2.2.2 Vitamin D and calcium in relation to bone health 31

3.2.2.3 Zinc in relation to thyroid metabolism 37

3.2.2.4 Anti-oxidants in relation to oxidative stress and cognitive functioning $\quad 37$

3.2.2.5 EGCG in relation to cognitive functioning, facial shape and body weight $\quad 39$

3.2.2.6 Multivitamin- and mineral mixes (including DS-specific formulas) 40

4 Discussion and conclusion

4.1 Main findings and discussion $\quad 42$

$\begin{array}{lll}4.2 & \text { Strengths and limitations } & 47\end{array}$

$\begin{array}{lll}4.3 & \text { Conclusion } & 47\end{array}$

$\begin{array}{lll}4.4 & \text { Recommendations for future research } & 48\end{array}$ 
References

Annex $1 \quad$ Ethical clearance

57

Annex 2 Survey parents

58

Annex 3

Interview questions

59

Annex 4 Literature search log 60

Annex 5 Labels dietary supplements 


\section{Preface}

\section{Stichting Downsyndroom}

In the Netherlands, the Dutch Down Syndrome Foundation (SDS) is the expertise center in the field of Down Syndrome. We attach great importance to scientifically sound knowledge on the basis of which parents and professionals can support the lives of people with Down syndrome. People with Down syndrome should be able to participate in society, in their own way, and with the necessary supports. The SDS consists of a small staff, and many committed parents and professionals. Very occasionally a parent offers us a wonderful opportunity to gain more knowledge, which was the case for this research project. Martine van der Mast-Ritsema is the mother of a son with Down syndrome and member of our foundation. She works at Wageningen University as program manager Nutrition and Health and she tipped us off that the Wageningen University \& Research Science Shop enables the conduct of research with social value. From her field of expertise and personal involvement, she did see opportunities for research into nutrition and Down syndrome. From the helpdesk of the SDS, we knew that parents have many questions about nutritional supplementation. All of these points led the Science Shop to have a study conducted on nutritional supplements for children with Down syndrome. With the results of this study, we can give parents and professionals good advice on this topic. And, we hope that a university is willing to fill the knowledge gaps found in this study through more applied research in the future.

We had a very pleasant collaboration with the Science Shop. We are grateful to the students who took on the various parts of the study, and to the researchers of Wageningen University who supervised them. We appreciate the work of the advisory board. Special thanks go to Sandra van der Haar, scientist and project leader Food, Health and Consumer Research, and Gerard Straver, coordinator of the Science Shop. They were the driving force behind this research.

On behalf of the SDS,

Regina Lamberts, director

Gert de Graaf, scientific officer

\section{Wageningen Food \& Biobased Research}

This report is the result of the research that we carried out for the SDS, within the framework of the Wageningen University \& Research Science Shop. It contains the result of two sub-studies: fieldwork and a literature study, aiming to investigate the use of dietary supplements in children with Down syndrome and the evidence for possible beneficial effects. In both parts, students from Wageningen University \& Research contributed in the data collection and analyses of results. The results in chapter 3 of this report partly overlap with the public student report of six master students (Arianne Aanstoot, Petra Dijkstra, Heleen van der Hout, Lisanne Renting, Lieke Verlind and Laura van Wijngaarden), who carried out the fieldwork in the context of the course Academic Consultancy Training (ACT). A summary of their findings is included in this report and the full student report can be obtained from the project website from the Wageningen University \& Research Science Shop. Two bachelor-students, Sanne van Wijk and Milou van de Beek, contributed in the literature study of the project. They wrote a bachelor thesis on this topic and their theses were used as input for this report. All aforementioned students are thanked for their contributions and enthusiastic working attitude. The advisory board of this project is thanked for valuable input and advice throughout the project. And last but not least, Gert de Graaf and Regina Lamberts from SDS are gratefully thanked for their input and for the pleasant collaboration.

On behalf of Wageningen Food \& Biobased Research, Sandra van der Haar, scientist and project leader 


\section{Summary}

Down syndrome (DS), also called trisomy 21 , is the most common genetic cause of intellectual disability. The overexpression of genes located on the extra copy of chromosome 21 causes typical physical and developmental characteristics of DS. Although with large inter-individual variability, people with DS can show distinct comorbidities in different stages of life. Attention to nutritional intake and status is important, since several comorbidities of the syndrome have nutritional consequences.

The use of dietary supplements in children with DS is widespread. Parents report improvements due to supplementation and manufacturers claim positive effects on health and cognitive functioning. It is however unclear whether there is scientific evidence for dietary supplementation in children with DS. Therefore, the central objective of this research project is to investigate the evidence for positive effects of the use of dietary supplements on health and cognitive function in children of 0 to 18 years old with Down syndrome. A secondary objective is to investigate patterns of dietary supplement use in the Netherlands, including parental motivations and expert opinions on dietary supplementation in children with DS.

The research consisted of two parts. First, fieldwork was performed consisting of an anonymous online survey among Dutch parents $(\mathrm{N}=234)$ and in-depth interviews with professionals $(\mathrm{N}=5)$ and parents $(\mathrm{N}=5)$. Second, an extensive literature search was conducted, to investigate the scientific evidence for dietary supplements in relation to health and cognitive outcomes in children with DS. Ethical clearance for the study was obtained from the Wageningen Social Ethical Committee (SEC).

The survey results showed that the majority of Dutch parents (61\%) administered dietary supplements to their child with DS. Within the group of 143 parents who provide supplements, vitamin D was the most frequently provided $(57 \%)$, followed by general multivitamins $(43 \%)$, vitamin C $(18 \%)$ and supplement formulas particularly aimed at people with DS (17\%). Parents most frequently indicated 'enhancing immune system (70\%)' as a motivation for supplementation. In the interviews parents indicated that they observed several positive effects or improvements in their child, as a result of supplementation. The interviewed pediatricians and dieticians were rather critical on the use of dietary supplements for children with DS. They indicated a clear preference for obtaining nutrients from the basic diet. At this moment, there are no recommendations on dietary supplements in medical or dietary guidelines for children with DS, except for the vitamin D advice for children aged 0-4 years, which applies for all Dutch children. An online search showed that the supplements Nutrivene-D $®$ and MSB-Neuroplus ${ }^{\circledR}$ are specifically aiming at people with DS. These type of supplements are not for sale on the Dutch market. European and Dutch regulations do not allow medical claims and/or claims linked to a specific disease on dietary supplements. The supplements can however be obtained from the US and Canada through the internet. Regarding dosages, in the Nutrivene-D ${ }^{\circ}$ supplement, vitamin B6 and zinc exceed the upper tolerable limits (UTLs) and for the MSB-Neuroplus $®$ supplement B6 exceeds the UTL in one age category (15-17 years old). In the Netherlands, the Netherlands Nutrition Center advices to not exceed $100 \%$ of the Recommended Dietary Allowance (RDA, in Dutch ADH: "Aanbevolen Dagelijkse Hoeveelheid") when taking a dietary supplement. These supplements are therefore not recommended.

The literature study revealed that there are several theoretical bases in literature, which could argue for dietary supplements in children with DS. First, deficiencies of zinc, vitamin A, D, vitamin B12, folic acid, calcium and iron seem to be more prevalent in children with DS (although not all studies confirm this). Secondly, people with DS seem to have higher oxidative stress levels and several mouse studies indicate positive effects of anti-oxidant supplementation. Thirdly, a few mouse studies show beneficial effects of EGCG on the brain and behaviour of mice. However, few clinical trials investigated the effects of dietary supplementation in health and cognitive outcomes in children with DS. The available evidence for positive effects on health and cognitive function as a results of dietary supplements is insufficient at this point. Therefore, there is a clear need for more well-designed, clinical trials with validated methodologies to reach consensus about the possible benefits of supplements for children with DS. Interesting is the working of EGCG and anti-oxidants, since potential beneficial effects on 
cognitive outcomes were also shown in a few human studies. The evidence to recommend these supplements to children with DS is however far too little at this point.

In conclusion, this research project showed that at present there is insufficient scientific evidence for cause-effect relationships between the use of dietary supplements and improvements in general health or cognitive functioning in children with DS. There is however some evidence that nutritional deficiencies are more common in children with DS, which can be due to feeding difficulties, drug use and the presence of comorbidities. When a deficiency is suspected, it is therefore recommended to perform blood level tests of micronutrient status on an individual level.

Based on the results of this project, several recommendations are distracted that the SDS can give to parents regarding dietary supplements (chapter 5 'Advice and Implications'). The results of this project have shown that relatively little research has been executed on dietary needs and supplements in children with DS. Consequently, parents and caretakers have little guidance on how to support their child's health and cognition in this regard. Therefore, there is a clear need for more well-designed, clinical trials to study the effects of several dietary supplements in children with DS. 


\section{List of definitions and abbreviations}

ACT
ADH
BMD
BMI
BMR
CD
CHD
CoQ10
Cu
DS
DV
EF
EU
EFSA
EGCG
GI
GORD
GTE
H2O2
HCY
IDA
IU
NIPT
OS
PPIs
RDA
RI
ROS
SDS
SEC
SOD
T1DM
TBARS
UTL
VAD
WUR
WFBR
Zn

ACT

BMD

BMI

CD

$\mathrm{CHD}$

CoQ10

$\mathrm{Cu}$

DV

EF

EFSA

EGCG

GORD

GTE

$\mathrm{H} 2 \mathrm{O} 2$

IDA

NIPT

OS

RDA

RI

ROS

SDS

SEC

T1DM

TBARS

UTL

WUR

$\mathrm{Zn}$
Academic Consultancy Training

Aanbevolen Dagelijkse Hoeveelheid

Bone Mineral Density

Body Mass Index

Basal Metabolic Rate

Celiac Disease

Congenital Heart Disease

Coenzyme Q10

Copper

Down syndrome

Daily Value

Executive functions

European Union

European Food Safety Authority

Epigallocathechin-3-gallate

Gastro-intestinal

Gastro-oesophageal reflux disease

Green tea extracts

Hydrogen peroxide

Homocysteine

Iron Deficiency Anaemia

International Units

Non-Invasive Prenatal Testing

Oxidative Stresss

Proton-Pump Inhibitors

Recommended Dietary Allowance

Reference Intake

Reactive Oxygen Species

Stichting Downsyndroom

Social Ethics Committee

Superoxide Dismutase

Type I Diabetes Mellitus

Thiobarbituric Acid Reactive Substance

Upper Tolerable Limit

Vitamin A Deficiency

Wageningen University \& Research

Wageningen Food \& Biobased Research

Zinc 


\section{Introduction}

This report contains the results of a scientific study investigating the current use and evidence for dietary supplements in children with Down Syndrome. The research was commissioned by the Stichting Downsyndroom (Dutch Down Syndrome Foundation), SDS, and funded by the Wageningen University \& Research (WUR) Science Shop. Wageningen Food \& Biobased Research (WFBR) executed the study independently, with contributions of a group of six Academic Consultancy Training (ACT) students and two BSc thesis students of both the Division of Human Nutrition \& Health and the Division of Health \& Society of Wageningen University (WU). Furthermore, an advisory board with experts in the field of Down syndrome, nutrition and supplements, contributed to this project and provided advice to the research team on the content of the project.

The SDS was founded in March 1988 at the initiative of a number of parents of young children with the condition. Their aim was to provide information on the syndrome and support parents in finding answers to their questions. One of these questions that often comes forward relates to the beneficial effects of dietary supplements. Much is being said about this topic: manufacturers claim positive effects on health and mental functioning and parents provide these supplements to their child under the guise "if it doesn't work, it doesn't harm". The SDS often receives questions on this topic through their helpdesk and they wanted to investigate the scientific base for providing supplements. With this question they decided to consult the WUR Science Shop.

The Science Shop is in charge of organizing research that is commissioned by non-profit civil society organizations, with limited financial means. Their goal is to generate direct societal impact by carrying out bottom-up research and by creating bridges between science and society. The research that is carried out is always linked to an area of expertise of WUR; such as food production and nutrition, health and lifestyle, sustainable agriculture, environmental quality, or processes of social change. The Science Shop appointed this project to the Food, Health and Consumer Research (FHCR) group of WFBR in November 2020.

\section{$1.1 \quad$ Background}

\subsubsection{Introduction to Down syndrome}

Down syndrome (DS), also called trisomy 21 , is the most common genetic cause of intellectual disability [1]. Normally each human cell contains 46 chromosomes, but in DS all or some of the cells contain an extra copy of chromosome 21 , or in rare cases, an extra part of chromosome 21 . The overexpression of genes located on this chromosome cause the typical physical and developmental characteristics of DS [2]. Physical characteristics that are more common in DS include a short height, small head and neck with a flattened face, short hands with broad fingers, clinodactyly (small middle phalanx of 5th finger), sandal gap deformity (increased space between the great toe and the other toes) and a protruding tongue. Limited cognitive functioning is the second common characteristic of people with DS, which can be classified according to their connection with specific functional and (or) anatomical brain abnormalities [3]. Intellectual disability is one of those prominent features, whereof the impairment can be mild, moderate or severe [4]. This cognitive impairment changes throughout the lifespan, and is altered by comorbid medical and psychiatric conditions like sensory impairment, autism, seizures, and sleep disruption. Cognitive functioning develops from childhood to early adulthood, and is followed by a decline in late adulthood, often recognized as dementia [3].

Language problems also form a limitation. In addition, children with DS have impairments in executive functions (EF), including deficits in attention, poorer response inhibition, lower processing speed, reduced verbal working memory, and difficulty in problem-solving, multitasking and self-monitoring. A reduction in learning capacity is seen as compared to children without DS, involving both short-term and long-term memory [3]. 
Social, emotional and behavioral functioning is different in individuals with DS. They are often recognized as 'charming' and 'sociable', as they seek out more social interaction compared to their peers [3]. On an individual level, children with DS show large variety in the aforementioned characteristics. Some have mild symptoms and complications, whereas others are more severely affected [5].

The live birth prevalence of DS varies per country due to differences in maternal age and prenatal screening [6-9]. For Europe, in the period 2011-2015, live birth prevalence is estimated at 10 per 10,000 live births for the different countries, ranging between 5 per 10,000 to 28 per 10,000 [10]. According to the most recent Dutch data from 2018, there were approximately 167 newborn children with DS in the Netherlands, corresponding to 9.9 per 10,000 newborns [11].

DS is often diagnosed postnatally by chromosomal analysis of an extra copy of chromosome 21 . Another option is prenatal screening during the first or second trimester. Prenatal screening determines the likelihood of babies being born with DS [2]. Since April 2017, non-invasive prenatal testing (NIPT) is offered to all pregnant women in the Netherlands in their first trimester [12]. If a positive prenatal screen is confirmed, expecting parents can use this information either for preparing for the birth of a child with DS, or decide to terminate the pregnancy. The probability of having a child with DS increases with the age of the mother [13].

People with DS can show distinct comorbidities in different stages of life, though with a large interindividual variability, affecting the cardiovascular, respiratory, gastrointestinal, neurological, sensory, endocrine, hematological, immune, musculosketal, renal and genitourinary systems [14, 15]. The prevalence of congenital heart disease (CHD) in children DS is about 44-58\% worldwide [16]. Gastrointestinal malformations occur in $1-10 \%$ of children with DS [2]. Besides these congenital anomalies, functional anomalies of the GI-tract are also commonly diagnosed in individual with DS, including celiac disease and gastro-oesophageal reflux disease (GORD) [15]. Celiac disease is seen in about 5$8 \%$ of children with DS [17], which is a more than 10 times higher prevalence as compared to the general population. In addition, DS is the most common genetic syndrome associated with immune dysregulation. As a result, individuals with DS are more susceptible to infections, malignancies and autoimmunity $[18,19]$. The underlying mechanisms of those immune disorders are highly complex and insufficiently understood, but probably an intrinsically deficient immune system or early ageing play a role [20]. Furthermore, DS is associated with thyroid dysfunction, both congenital (existing from birth), and acquired (developed after birth). The prevalence of hypothyroidism (a too slow working thyroid) varies among gender and race, and by age. It is estimated at 20 per 1000 in schoolaged children with DS, 50 per 1000 in adolescents, and 100 per 1000 in adults [21]. A second endocrine disorder commonly observed in people with DS is type I diabetes mellitus (T1DM). A study of Bergholdt et al. (2006) estimated that people with DS are four times more likely to develop T1DM compared to the general population of similar age [22]. Also, DS is associated with a higher risk of developing (premature) dementia [23, 24].

Even though the life trajectory of people with DS can be complex because of medical, psychological, or social issues from infancy through adulthood, persons with DS and their families generally have a positive attitude and express a desire for a high quality of life [25]. In recent decades, a substantial increase in the life expectancy of people with DS was observed, which is now approximately 60 years. This is a result of early management of comorbidities, together with better healthcare and educational advances $[26,27]$. In the Netherlands, children with DS are under supervision of a pediatrician or an outpatient clinic specialized in DS (In Dutch "Downpoli"). These pediatricians all follow the DS medical guidelines in their treatment of children with DS in the Netherlands [21].

\subsubsection{Nutrition-related health problems in children with Down syndrome}

In children with DS, attention to nutritional intake and status is important, since several features and comorbidities of the syndrome can have nutritional implications and consequences. There is however a large inter-individual variability in these health problems related to nutrition [5]. 
About 55-60\% of children with DS experience difficulties in feeding and swallowing [28, 29]. Reasons are the lower truncal tone and oral motor function [15]. Also, children with DS are more susceptible to periodontal disease due to their immune dysregulation. As a result tooth loss can occur. Lastly, individuals with DS often suffer from dysphagia [30]. This can result in lower (self)feeding abilities and thereby inadequate nutritional intake. Furthermore, as mentioned above, there is a higher risk of celiac disease, and thereby also a $20 \%$ higher risk of developing osteoporosis [31]. Celiac diseases can cause additional complications such as abdominal pain and chronic constipation. Chronic constipation can also be caused by other characteristics common in DS, such as hypotonia of the abdominal muscles and a disturbed intestinal motility [32]. In addition, diabetes mellitus type I occurs four times more often in people with DS, as compared to the general population [5, 22]. Also thyroid dysfunction is more common, possibly affecting metabolism and thereby, if not diagnosed and treated adequately, resulting in slower growth, constipation and obesity. Furthermore, there are indications that some nutritional deficiencies (amongst others vitamin D, iron and zinc) are reported more frequently in children with DS [33,34]. A recent meta-analysis of 69 studies showed that overall micronutrient status is different in both children and adults with DS as compared to people without DS, showing significantly decreased copper, selenium and zinc levels and increased calcium and sodium levels [35].

While children with DS often experience feeding difficulties in early childhood, there is a tendency towards developing obesity when the age of the child increases. Already from 4 or 5 years of age, overweight can be a concern [5]. Energy metabolism in people with DS is probably shifted due to the extra copy of human chromosome 21 (Hsa21). This shift turns out to be an important determinant in the progress of pathological disorders associated with DS. Shifts in mitochondrial function, increased oxidative stress levels, impaired glucose, and lipid metabolism all contribute to reduced energy production and cellular dysfunctions. These shortcomings in molecular functioning elucidate the high prevalence of metabolic disorders like diabetes and obesity in DS [36]. In the Netherlands, children between 2 and 18 years old with DS are twice as often obese as children without DS (26\% vs. 13\% in boys and $32 \%$ vs. $15 \%$ in girls) [37]. Possible determinants of obesity, particularly in children with DS, are increased leptin levels, decreased basal metabolic rate (BMR) and comorbidities like hypothyroidism, congenital heart disease and obstructive sleep apnea. Other risk factors include drug use (certain antidepressants, antipsychotics and anti-epileptics), unfavorable dietary patterns (high energy intake and low-nutrient intake) and low physical activity [38, 39]. Several studies suggest that children with DS have a relatively low energy requirement, however there is no consensus about this topic in literature [39]. There are three theories about this possible lower energy requirement. Those include leptin resistance, a lower BMR and low physical activity together with overeating [40].

Eating behaviors in children with DS are also different from children without DS. Studies have shown that children with DS often continued to eat as long as food was present, were picky concerning food choices, and swallowed without sufficient chewing [41]. Furthermore, Grammatikopoulou et al. (2008) observed an obviously higher energy intake in teenagers with DS (aged 10-18 years) compared to children with DS (aged 2-9 years). Overall, the children with DS in this study consumed healthier foods than the teenagers, as the children are more dependent on the food provision by their parents [42]. Because of these nutrition related problems and aberrant eating behaviours, excessive or deficient nutrient uptake should be of concern in children with DS.

\subsubsection{Dietary supplements in children with Down syndrome}

The use of dietary supplements in children with DS is widespread. Common dietary supplements are being used, but there are also supplements on the market particularly developed for people with DS. These supplements make use of various combinations of vitamins, minerals and other ingredients, aiming at improving cognitive and physical functioning, immune system and quality of life in children with DS. Dietary supplements are available without prescription, and usually come in tablet, powder or liquid form.

Several studies have investigated patterns of dietary supplement use in DS. A large study among 1167 parents in the United States (but also including some respondents from Brazil, Poland, England and the European Union), showed that $49 \%$ of respondents currently give, or previously gave their 
child supplements, with Nutrivene-D® (multivitamin formula specific for DS), curcumin and green tea extract being the most commonly used [43]. Another study carried out in the United States investigated the usage of and attitudes to green tea extract and Epigallocathechin-3-gallate (EGCG) among parents of children with DS [44]. EGCG is the major polyphenol (50-75\%) found in green tea extracts and is hypothesized to improve cognitive function and developmental phenotypes associated with DS. The results showed that $13.5 \%$ of the 348 parents gave green tea extract or EGCG to their child and $4.9 \%$ had given it in the past. In the Netherlands patterns of dietary supplement use have to our knowledge not yet been studied.

As described in 1.1.2, some nutritional deficiencies might be more prevalent in DS. In these specific cases, dietary supplementation could in theory be a good way to complement vitamin and mineral intake from the regular diet, in order to achieve a healthy nutritional status. However, whether children with DS indeed more often have nutritional deficiencies has to be further investigated.

Regarding supplements specifically aimed at people with DS, parents sometimes report improvements due to supplementation, whereas other parents do not report any differences [44]. In literature, some studies report beneficial effects of dietary supplementation. For example, the positive effects of green tea extracts (GTE) containing Epigallocathechin-3-gallate (EGCG) on improving certain cognitive functions has been reported in a recent pilot study in individuals with DS and in DS mouse models [44]. It is still unclear whether there is scientific evidence to support claims that dietary supplementation could lead to beneficial effects in children with DS, and whether these type of supplements are safe to use. Therefore, in order for the SDS to correctly inform parents on this topic, it is necessary to further investigate patterns of use and the current scientific evidence for beneficial effects.

\subsection{Objective and research questions}

The central objective of this research project is to investigate the evidence for the use of dietary supplements in children of 0 to 18 years old with Down syndrome.

A secondary objective is to investigate patterns of usage of dietary supplements and parental motivations.

1. Which dietary supplements are being used in practice? And what are motivations of parents to provide their child with supplements?

2. What do doctors, dieticians and other professionals advise on this topic?

3. Which dietary supplements for people with Down syndrome are on the market? What do they claim and do they contain safe doses?

4. Is there a theoretical basis in the literature why children with Down syndrome would need or could benefit from dietary supplements?

5. Is there scientific evidence for the effectiveness of supplements in relation to health or cognitive functioning?

- If yes: which supplements are effective and in which doses?

6. Which practical advice should the SDS give to parents regarding this topic? 


\section{Methods}

The current research project was composed of two different parts. First, to investigate the current situation regarding dietary supplementation in children with DS in the Netherlands, fieldwork was performed between January and March 2021. This fieldwork consisted of an anonymous online survey among parents, in-depth interviews with both professionals and parents, and an online inventory of supplements currently available on the market. Research question 1 to 3 were addressed in this fieldwork. Second, an extensive literature search was conducted between February and June 2021, to investigate the scientific evidence for dietary supplements in relation to health and cognitive outcomes among children with DS. Research question 4 and 5 were answered by studying the available literature. Research question 6 was answered based on the results of the aforementioned research questions 1 to 5 . Ethical clearance for the study was obtained from the Wageningen Social Ethical Committee (SEC), see Annex 1. Below the methods for both parts of the project are described.

\section{$2.1 \quad$ Fieldwork}

The fieldwork was carried out by a group of six master students in the context of the course Academic Consultancy Training (ACT). This is a mandatory 8-week course for all master students of Wageningen University. The students signed up for this specific assignment (based on their interest) and were matched based on their master programmes (MSc Nutrition and Health and MSc Health and Society). The commissioners for the assignment were WFBR, SDS and the Science Shop. During the 8 weekperiod, the team was guided by a process coach (Beitske Bouwman) and an academic advisor from WUR (Nicole de Wit). The deliverable of this ACT-group was a student report with the main findings of a brief literature search and of their fieldwork (online survey among parents, in-depth interviews with both professionals and parents, and an online inventory of supplements currently on the market). This report is publicly available and can be obtained through the project website via the Science Shop. The results of the fieldwork were used as input for chapter 3.1 of this overarching report.

\subsubsection{Survey among parents}

The ACT students developed a short survey, consisting of 22 open- and multiple-choice questions to investigate current use of dietary supplements and motivations among parents of children with DS in the Netherlands. The survey questions were based on available papers on this topic and on previous surveys and experiences of the SDS. The commissioners (WFBR and SDS) provided feedback on the questions. The final survey contained questions on whether parents provided supplements to their child, the type of supplements, frequency and doses, motivations for (not) using supplements and source(s) of information they used for making their decision. Furthermore general characteristics of the parents (gender, level of education) and the child (age, general health, BMI) were included. The survey can be found in Annex 2.

The survey was programmed in Logic8 EyeQuestion version 4.11 and the link was shared through the newsletter and social media platforms of the SDS and through other Facebook groups with parents of children with DS. Both parents providing supplements and parents not providing supplements to their child were approached. Selection criteria for participation in the survey were being a primary caregiver of at least one child aged 0-17 years with DS and having a good understanding of the Dutch language. Before filling out the questionnaire, participants gave their consent for participating in the research and the use of their (anonymous) data for this study. Additionally, information regarding the anonymity and storage period of the results was provided. Three gift cards of $€ 20$ were raffled among all respondents. 


\subsubsection{Interviews with parents and professionals}

The ACT students held in-depth interviews with two pediatricians and two dieticians specialized in DS. In addition, five parents of children with DS were interviewed. The participants were approached through the advisory board of the project and through the SDS. Prior to the interview, the participants were asked to sign a consent form. The interview consisted of 12 to 16 open-end questions, concerning the use of, experience with and opinion on nutritional supplements for children with DS. A separate interview was designed for the founder of NutriChem. NutriChem developed a supplement (MSB NeuroPlus $®$ ) specifically aimed at people with DS. This interview consisted of 14 questions. The interview questions were discussed with the commissioners of the ACT-group (WFBR and SDS) and adapted based on these suggestions. All interview transcripts were sent back to the persons in question for approval and a small present was sent by post afterwards. The interview questions for alle interviews can be found in Annex 3.

\subsubsection{Inventory of dietary supplements}

An online search was performed by the ACT-students to explore which DS-specific supplements are currently on the market. Based on their search and report, an overview was made for this overarching report, describing the type of supplement, ingredients, claimed health effects by the manufacturers and the dosages. The dosages were compared to guidelines from the 'Nederlandse Voedingsmiddelentabel' (Netherlands Nutrition Center 2016) to see if the daily recommended dosages of the supplements were within the safe range. In this overarching report, we elaborate a bit more on the findings of the ACT-students, regarding the safe doses of two of the supplements specific for DS, with additional comparisons to safe upper limits for children according to EFSA (European Food Safety Authority).

\subsubsection{Data analyses}

As described above in 2.1.3, the ingredients of the DS-specific supplements were put in an overview table, and compared to the guidelines of the Netherlands Nutrition Centre. The data obtained from the questionnaire among parents was analyzed in IBM SPSS Statistics 26. The ACT-group performed the analyses of the survey questions, with input and feedback from their academic advisor. Descriptive statistics were used to depict the results obtained from the questionnaire. For some analyses, results were split into groups based on age and gender of the child with DS or based on whether the child was provided with nutritional supplements or not. For the continuous variables means and standard deviation were calculated. For categorical/ordinal variables, frequency tables were made.

In addition to the abovementioned analyses of the ACT-group, an additional analysis was performed by WFBR to compare the group of parents who provide DS-specific supplements to the group who provides more general dietary supplements. Respondents were categorized into these two groups, according to the supplements they indicated to provide to their child in the survey. Percentages were calculated and compared. Fisher exact tests were performed to assess whether motivations were significantly different between these two groups.

The interviews were recorded and transcribed verbatim. For the analyses, the interviews were anonymized. The interview of the founder of NutriChem could not be anonymized as was discussed with him. The interviews were split into fragments based on the specific topics discussed in the interview. Subsequently, each of these fragments were labeled according to the following categories: dietary pattern, nutrition-related problems, nutritional deficiencies, nutritional supplements, recommendations, scientific evidence for effectiveness supplements, necessary dietary supplements and trust in medical profession. Afterwards, the labeled fragments were grouped according to their content. Eventually, a summarizing text was made out of these findings. The full text can be found in the report of the ACT-group. In this report, a summary of the interview findings is included. 


\subsection{Literature study}

The literature study was carried out by several persons and consisted of different activities. Firstly, a systematic literature search was performed in February 2021 by an information specialist of the WUR library in Pubmed and Scopus. The search strategy was developed in collaboration with WFBR, and a few members of the advisory board gave input on the search terms (See Table 1). The final search log can be found in Annex 4. Next to the search terms, an additional criterium was that Down syndrome had to be in the title or keywords.

Table $1 \quad$ Overview of search terms that were used in the literature study.

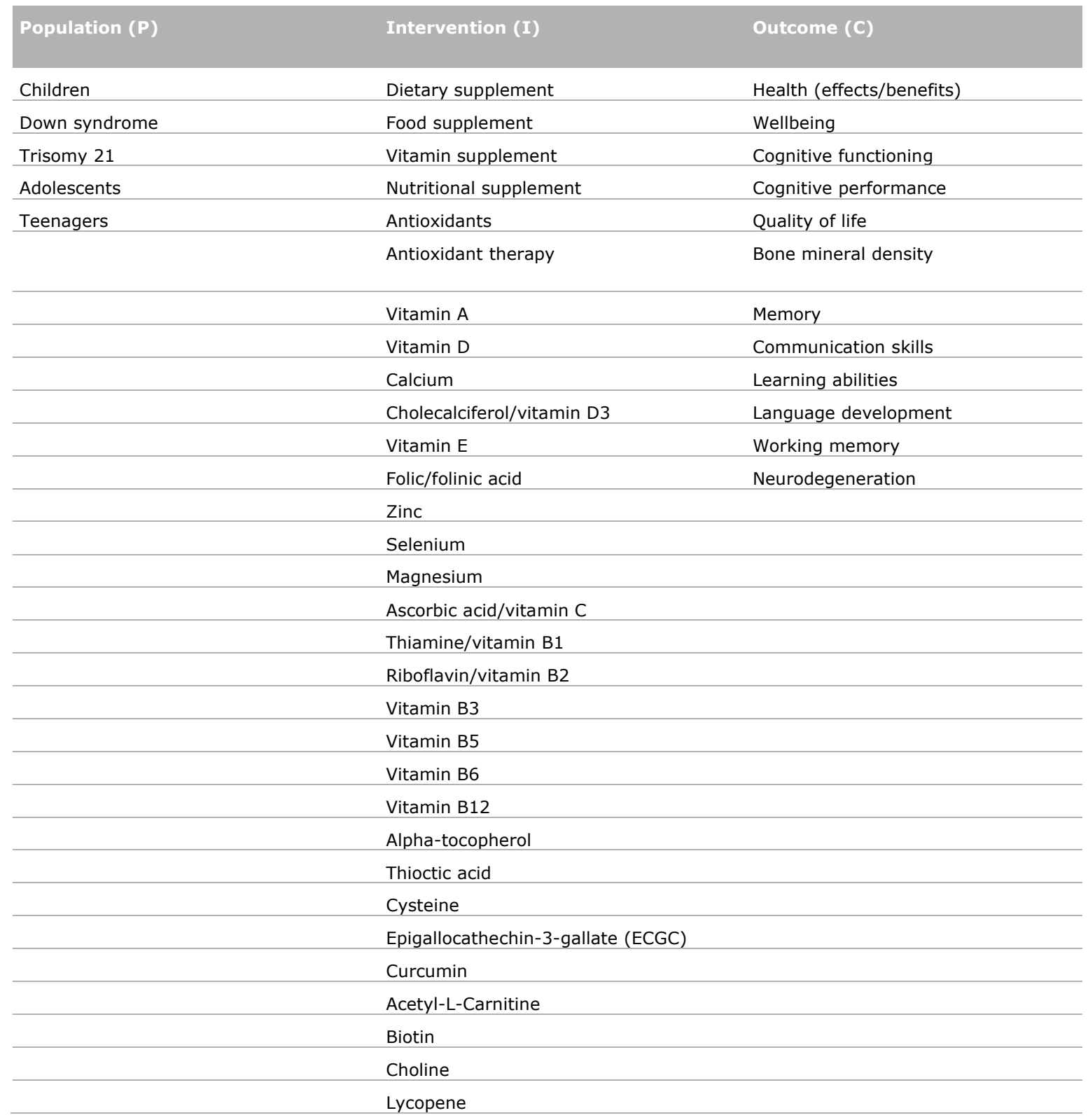

Next to the search of the information specialist, the BSc-students, ACT-students and WFBR scientists searched for relevant literature in Pubmed and Scopus, making use of the above mentioned search terms. They also looked into often cited papers, reference lists of obtained papers, and a few members of the advisory board shared relevant literature or practical guidelines on the topic. This resulted in a total of 227 papers. Based on title, abstracts and our research questions relating to health and cognitive outcomes, 56 titles were selected to be relevant for our research purpose and for the theses of the bachelor students. These papers were summarized in an Excel-sheet by the two bachelorstudents and two scientist of WBFR, describing the type of study, the intervention (if any), main results and conclusions of the paper. In the Excel-file a distinction was made between studies 
describing effects on health and health biomarkers, studies describing cognitive effects and studies used for the introduction and theoretical framework of this report.

To study the evidence for dietary supplements (research question 5), an overview table describing clinical trials was included in chapter 3.2 of this report. A total of 18 trials were included.

The trials that were selected for this table, had to comply to the following criteria:

- $\quad$ Study is investigating the effects of a certain type of dietary supplement on either health or cognitive outcomes.

- Study was carried out in children 0-18 years.

- $\quad$ Studies in adults with DS were not included, unless the study sample contained both adults and children under 18 years in the same study sample.

- $\quad$ Published in the past 20 years (from 2001 onwards). 


\section{Results}

\section{$3.1 \quad$ Fieldwork}

The coming paragraphs (3.1.1 to 3.1.4) contain a summary of the main findings from the fieldwork that was carried out by the ACT students (survey, interviews and an online search for supplements). The aim was to explore the current situation regarding dietary supplementation in children with DS among parents and professionals, thereby providing an answer to research question 1 to 3 . The full student report can be obtained via the Science Shop project website. Additional analyses on the survey were performed by scientists of WFBR in 3.1.2, to have a deeper look into motivations of parents who provide DS-specific supplements. Furthermore, explanatory tables were prepared by WFBR in 3.1.4, in order to compare ingredients of the dietary supplement formulas for DS to EFSA recommendations for safe dosages.

\subsubsection{Survey results}

A total of 234 complete surveys were analyzed. The characteristics of the respondents and main characteristics relating to supplement use are displayed in Table 2 . The large majority of the sample was female (93\%). The majority of parents $(61 \%)$ reported to provide dietary supplements to their child and a small percentage ( $9 \%)$ indicated to have provided supplements in the past, but not at this moment. The remaining $30 \%$ indicated not to provide supplements.

Table 2 Sample characteristics and findings regarding dietary supplement usage.

\begin{tabular}{|c|c|c|}
\hline Survey items & Mean (SD) & $N(\%)$ \\
\hline \multicolumn{3}{|c|}{ Sample characteristics (respondents) } \\
\hline Total & & 234 \\
\hline Female & & $218(93 \%)$ \\
\hline Medium education level & & $59(25 \%)$ \\
\hline High education level & & $158(68 \%)$ \\
\hline \multicolumn{3}{|l|}{ Characteristics child } \\
\hline
\end{tabular}

\begin{tabular}{ll}
\hline Supplement usage & \\
\hline Yes & $143(61 \%)$ \\
\hline No, but in the past & $20(9 \%)$ \\
\hline No & $71(30 \%)$ \\
\hline Age at which dietary supplement usage started: & $3.7(4.6)$ \\
\hline Between 0-1 years & total 134 \\
\hline Between 2-4 years & $66(49 \%)$ \\
\hline Between 5-8 years & $38(28 \%)$ \\
\hline Between 9-12 years & $15(11 \%)$ \\
\hline Between 13-17 years & $10(7 \%)$ \\
\hline
\end{tabular}

The parents who gave supplements ( $61 \%$ of the total sample) were asked which type of supplements they provided. Furthermore, a rather large group (16\%) indicated to provide other supplements, that were not mentioned in the answering options of the survey. 
Figure 1 shows their responses. The most provided supplements were vitamin $D(57 \%)$, multivitamins $(43 \%)$, vitamin C (18\%), DS-specific multivitamins (e.g. Nutrivene-D $®$ and MSB NeuroPlus $®)(17 \%)$, probiotics (11\%) and fish oil (9\%). Specific supplements suggested in literature for DS such as EGCG, cysteine and curcumin, were only provided by $3 \%, 1 \%$ and $1 \%$ of the parents respectively. Furthermore, a rather large group (16\%) indicated to provide other supplements, that were not mentioned in the answering options of the survey.

Figure 1 Type of dietary supplements given by Dutch parents $(n=143)$ shown in percentages ${ }^{a}$.

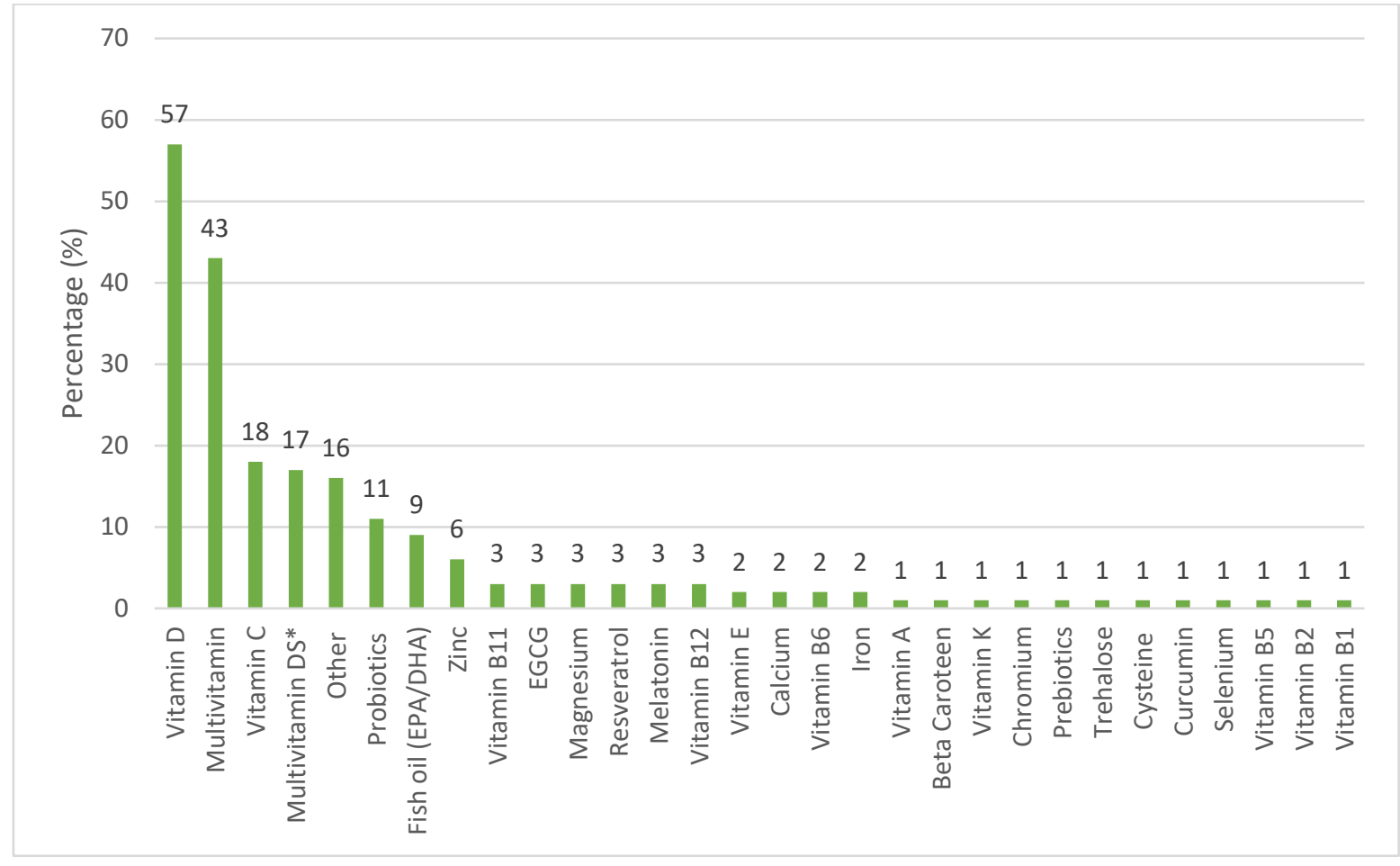

${ }^{a}$ Respondents could indicate multiple answers

* Multivitamin formulas aimed at Down Syndrome

When looking at dosages of the most frequently supplemented nutrients, vitamin $D$ is often provided in amounts ranging from $7,5 \mathrm{mcg}$ to $40 \mathrm{mcg}$, with most respondents indicating that they give $10 \mathrm{mcg}$, which is the recommended amount for healthy children aged 0-4 years [45]. The amounts for vitamin $\mathrm{C}$ were highly variable. Most respondents however, reported vitamin C dosages ranging from 100 to $1000 \mathrm{mg}$. The recommended daily intake for vitamin C in The Netherlands ranges from 20 to $75 \mathrm{mg}$ for children aged 0-17 years [46], and there is no upper limit. Most respondents indicated to provide more than the recommended intake. For the general multivitamins, the brands Davitamon and Kruidvat were most often reported. Respondents providing their child with these general multivitamins mostly reported giving the multivitamin in the dosage recommended on the label or half this dosage.

Regarding motivations for (not) providing supplements, the respondents were split into three groups: parents who indicated to give supplements $(N=143)$, parents who did not give supplements $(N=71)$ and parents who did give supplements in the past, but currently not $(\mathrm{N}=20)$. Multiple motivations could be selected by the respondents.

Figure 2 shows the motivations for providing dietary supplements in the group of current users. The most frequently selected motivation was to enhance the immune system of their child (70\%), followed by recommendations from the child's physician (29\%) and deficiencies (22\%). Only $6 \%$ of parents did not have a specific reason for providing dietary supplements, indicating that the majority of parents provides supplements with a specific reason. Reasons for not providing supplements in the group of non-users are shown in Figure 3. The most frequent mentioned reason was that they did not think it was necessary to give their child supplements (49\%), followed by 'I haven't thought of giving my child supplements' (44\%). 
Figure 4 shows the reasons for quitting giving supplements. The majority indicated they did not have a specific reason for that (50\%), or that they had other reasons (50\%). Another $20 \%$ indicated they did not see an effect of nutritional supplementation.

\section{Figure 2 Motivations for dietary supplementation in current users $(n=143)^{a}$.}

To enhance my child's immune system My child's physician recommended this Because my child (probably) has a nutritional deficiency Because my child does not get these nutrients from... Another caregiver of a child with Down syndrome.

To give my child more energy during the day

Other

To counter early-onset aging

To enhance my child's learning abilities Another health expert recommended this

To enhance my child's physical performance I don't have a specific reason for supplementation but.

My child's dietician recommended this

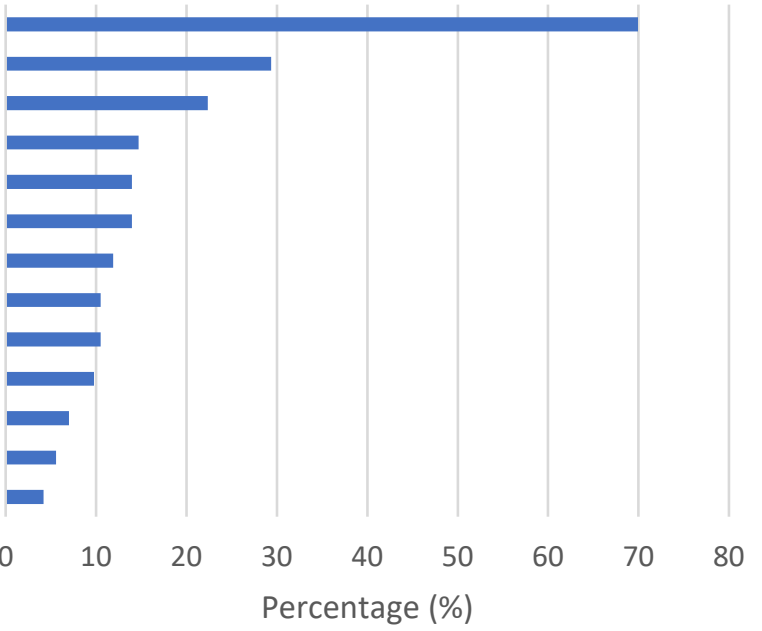

${ }^{a}$ Respondents could indicate multiple answers

Figure 3

Motivations for not providing dietary supplementation in non-users $(n=71)$ a.

I don't think it's necessary to give my child supplements

I haven't thought of giving my child nutritional supplements

My child does not want to take nutritional supplements

Other
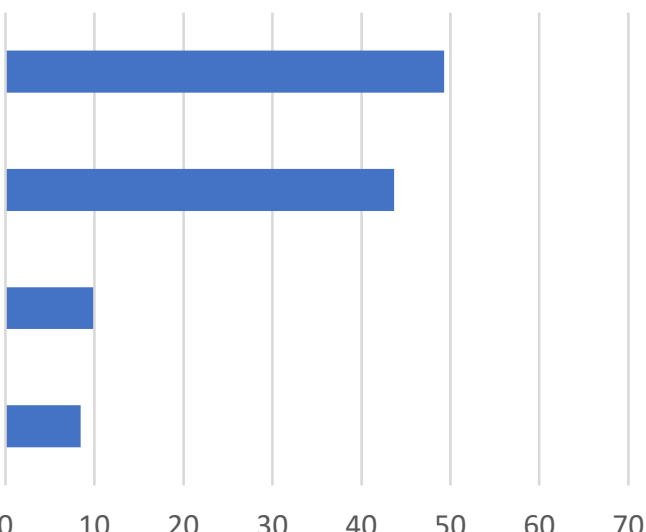

Percentage (\%)

a Respondents could indicate multiple answers 
Figure 4 Motivations for quitting dietary supplementation $(n=20)^{a}$.

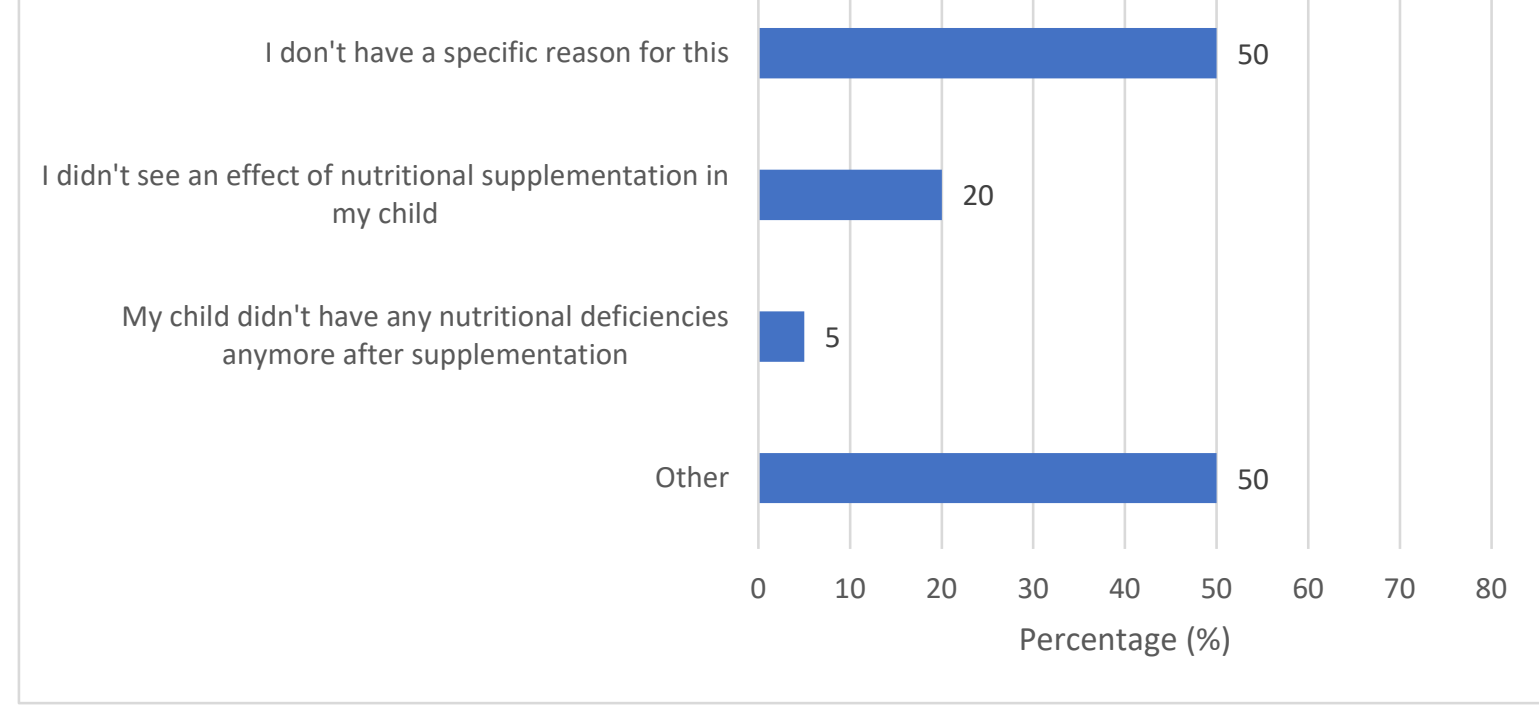

${ }^{a}$ Respondents could indicate multiple answers

Figure 5 shows on which source of information parents base their decision to provide supplements. The majority (55\%) indicated they do not have information about supplements. Most parents that did use information, obtained this via a physician (48\%), the internet (34\%), social media (30\%) or people in their network (25\%). A small group (17\%) based their decision on scientific literature.

Figure 5 Source of information for providing dietary supplements in users $(n=143)^{a}$.

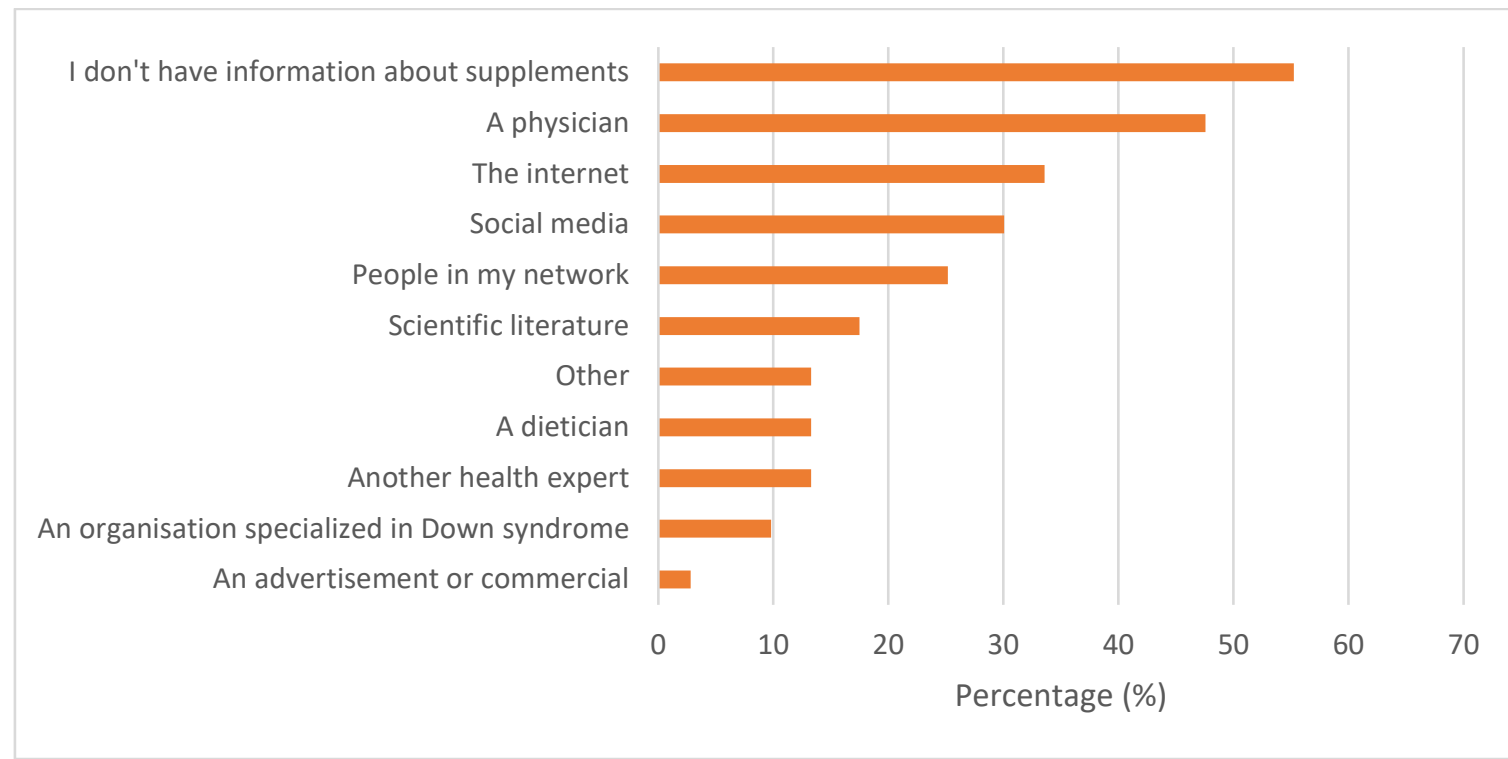

${ }^{a}$ Respondents could indicate multiple answers

\subsubsection{Additional analyses online survey}

Part of the survey data was further analysed by WFBR. The group of parents who provided a supplement specifically aiming at people with DS, versus the group of parents who provided other dietary supplements, were compared regarding their demographics, motivations and sources of information. The characteristics of both samples are displayed in Table 3. In both samples the large majority was female. In the DS-specific supplement group, a larger percentage had a high education ( $86 \%$ vs. $70 \%$ ), however this difference was not significant. The mean age of the child of the respondents was significantly higher in the general dietary supplement group $(9.5 \pm 5.0)$ than in the DS-specific supplement group $(7.8 \pm 3.4)$. 

general supplement on demographics.

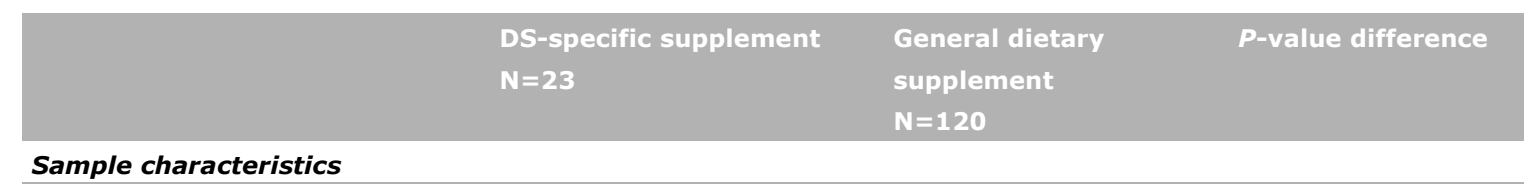

Sample characteristics

\begin{tabular}{llll}
\hline Gender & & & 0.24 \\
\hline Men & $2(9 \%)$ & $4(3 \%)$ & $116(97 \%)$ \\
\hline Women & $21(91 \%)$ & & 0.22 \\
\hline Education & $N=22$ & $N=188$ & $4(3 \%)$ \\
\hline Low & $1(5 \%)$ & $31(26 \%)$ & $83(70 \%)$ \\
\hline Middle & $2(9 \%)$ & & $0.01^{*}$
\end{tabular}

* significant difference

Figure 6 shows that parents' motivations for supplementation with a DS-specific supplement are different than motivations for providing a general dietary supplement. The most important motivation for the whole sample (enhancing immune system), is still the most important motivation in both groups ( $74 \%$ vs. $64 \%$ ). However, more energy (39\% vs. $8 \%$ ), enhancing learning abilities ( $52 \%$ vs. $2 \%$ ), enhancing physical performances ( $26 \%$ vs. $3 \%$ ) and encountering early-onset ageing ( $52 \%$ vs. $3 \%$ ) were mentioned significantly more often in the DS-specific supplement group. 'Other parents of a child with DS recommended it' was also mentioned significantly more often in this group (61\% vs. $4 \%)$.

Figure 7 shows that the source of information also differs for the DS-specific-formula group. The internet ( $52 \%$ vs. $20 \%$ ), social media (74\% vs. $13 \%)$, scientific literature ( $44 \%$ vs. $8 \%$ ) and people in the network ( $30 \%$ vs. $17 \%$ ) were mentioned significantly more often. The advice for general dietary supplements occurred significantly more often on the advice of a physician ( $37 \%$ vs. $13 \%$ ). 


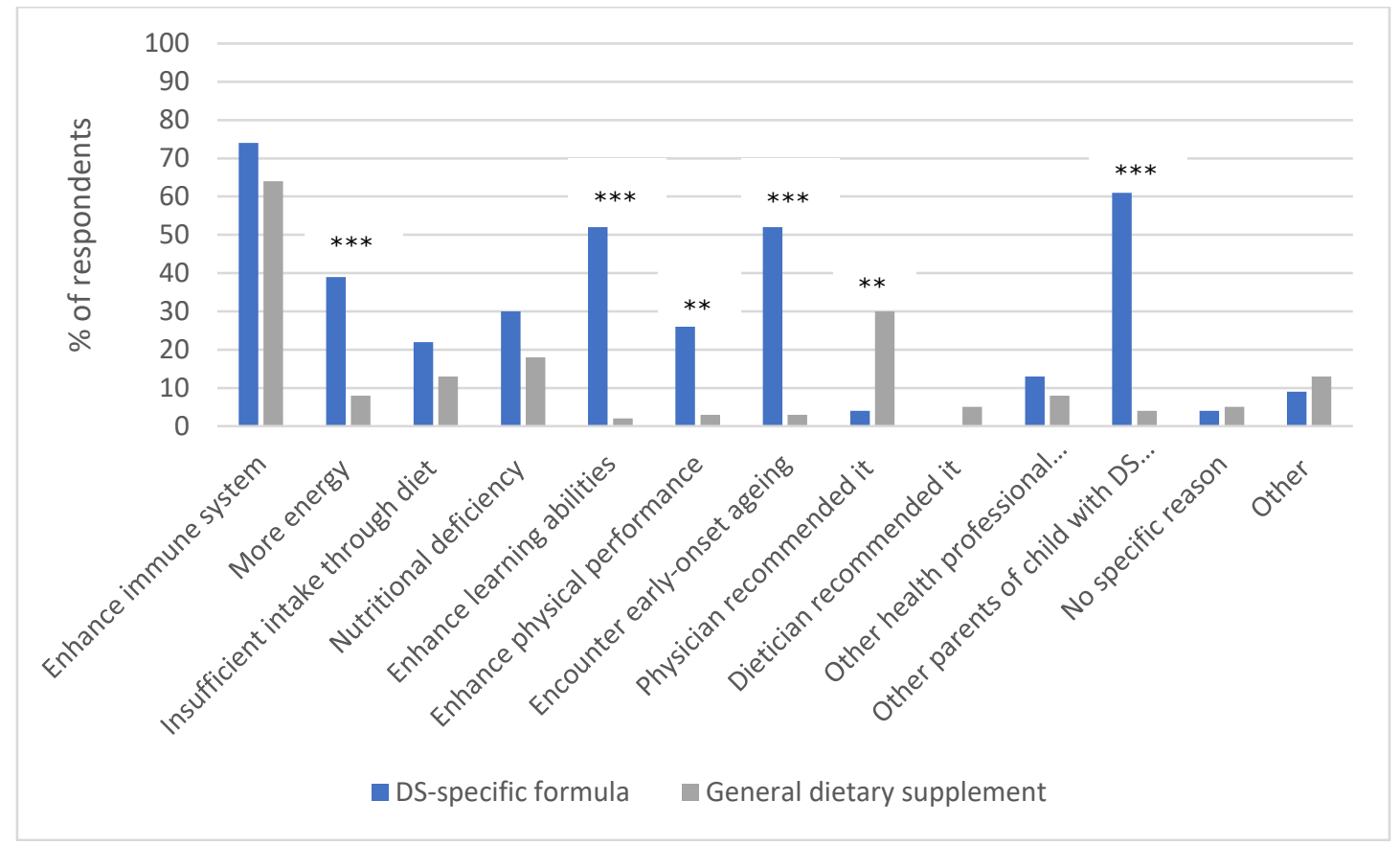

Figure 6 Reasons for dietary supplementation - percentages of parents who provide a DS-specific formula $(\mathrm{N}=23)$ versus parents who provide a general supplement $(\mathrm{N}=120)$; significant differences are indicated as $* *=p<0.01$ and $* * *=p<0.001$.

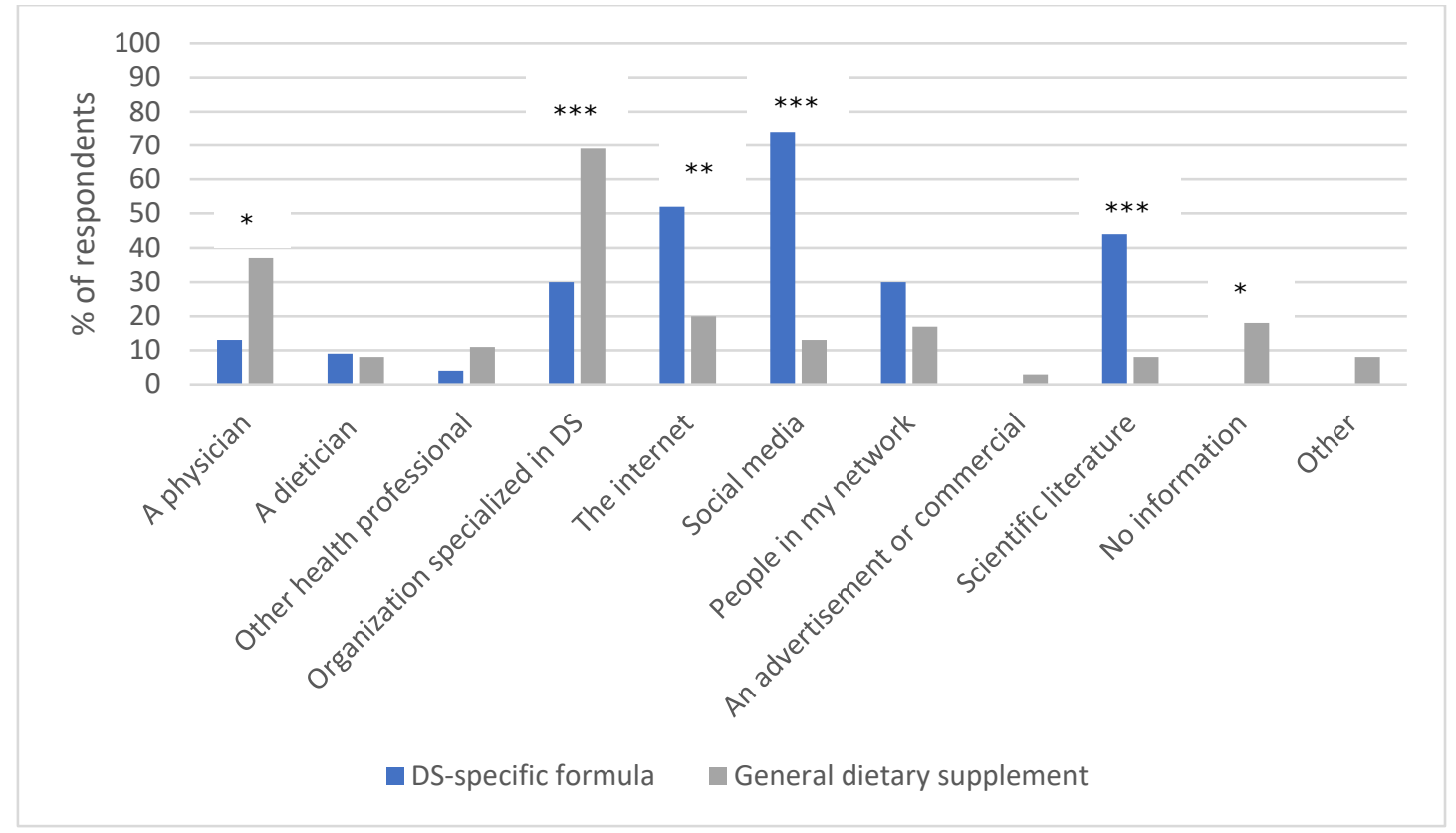

Figure 7

Source of information for dietary supplements - parents who provide a DSspecific formula $(\mathrm{N}=23)$ versus parents who provide a general supplement $(N=120)$; significant differences are indicated as $*=p<0.05, * *=p<0.01$ and $* * *=p<0.001$.

\subsubsection{Interviews}

The ACT students carried out and analysed a total of 10 interviews: five interviews with parents and five interviews with experts (two doctors, two dieticians, one supplement manufacturer). The aim of the interviews with parents was to obtain more in-depth information on motivations for (not) providing dietary supplements, knowledge and attitudes regarding this topic, and perceived benefits of dietary supplements. The aim of the interviews with experts was to hear their opinion and advice on dietary 
supplements for children with DS. The full results of the interviews can be found in the ACT studentreport. Below, the main findings are shortly discussed.

\subsubsection{Results interviews with parents}

Four out of the five parents indicated to provide dietary supplements to their child. The fifth parent only provides a multivitamin during the winter months. Two parents indicated to currently use supplements specific for DS. There were different motivations for providing supplements. All four parents that provided supplements, noticed positive effects on the development and overall health of their child. The other parent was rather neutral regarding the use of supplements: this person thought that they might be beneficial, but that nutrients should be mainly obtained from basic nutrition.

All but one of the parents were familiar with Nutrivene-D $\AA$ and MSB NeuroPlus $\AA$, the specific supplement formulas aiming at people with DS. One of them studied the scientific base for it. Two of the five parents were convinced that dietary supplements have a positive effect on the development of their child, even though one of them also mentioned that it is impossible to say something about the effect of supplements based on just one person. Still, they focused on the positive effects they noticed in their own child. Improvements they mentioned, were positive effects on bowel movement, cognitive functioning and a growth spurt. One parent mentioned quitting the MSB NeuroPlus ${ }^{\circledR}$ supplement and experienced that within a week, the child was already more tired, less alert and got a poorer skin. One parent was shocked by the high amounts of vitamins and minerals in the MSB NeuroPlus $\circledR$ and Nutrivene-D® supplements. One parent described once seeing a post about possible negative sideeffects of the MSB NeuroPlus ${ }^{\circledR}$ supplement (a child that turned yellow and the urine turned brown), so this parent was rather sceptical. This is the parent who is not giving supplements to her child.

Two parents indicated that paediatricians do not recommend supplements, because there is no scientific evidence for it. Of these two parents, one parent disagreed to the fact that there is no scientific evidence, and the other parent still decided to give supplements because of the positive effects she noticed herself. One parent mentioned a feeling of neglect by the medical experts, as an expert mentioned to her that he did not prescribe nutritional supplements. This parent believed that the medical protocols are more focused on treatment rather than on the prevention of certain diseases. On the contrary, the parent who is not providing supplements indicated to have complete trust in the medical specialist of the child regarding this topic. Regarding future studies, one of the parents mentioned that there is not much hope for extensive research. This parent believed that children with DS form a rather uninteresting target group for research due to decreasing numbers of new-borns with DS.

\subsubsection{Results interviews with experts}

The interviewed doctors and dieticians $(\mathrm{N}=4)$ were all rather critical on the usage of supplements, as they indicated a clear preference for obtaining nutrients from basic foods. They hold the view that if necessary, supplements may be used in case of specific deficiencies. One expert specifically pointed out that vitamin $\mathrm{D}$ can be taken in addition to the regular diet.

All experts reported that at this moment there is nothing included within the DS treatment guidelines about the use of dietary supplements. For children with and without DS, the general guidelines for healthy nutrition are used ("Richtlijnen Goede Voeding" Health Council of the Netherlands [47]). Two of the experts indicated that there is not enough scientific evidence for the effectiveness of dietary supplements for children with DS. One expert stated that practice-based proven theory is sometimes also taken into account, as the expert mentioned not to immediately disapprove a supplement if a parent is interested in giving it to their child. However, this expert indicated that he will always search for information about the specific supplement, as the supplement should, by all means, not cause any damage to health. This was also mentioned by one of the other experts, indicating that some supplements can cause damage in high doses. One expert said that if the parent wants to give a supplement, he would advise supplements that contain less than $100 \%$ of the Recommended Dietary Allowances (RDA, in Dutch ADH: "Aanbevolen Dagelijkse Hoeveelheid). Two experts advise to recommend supplements based on individual needs, as it is too difficult to prove anything scientifically about nutrition in general, given the wide diversity. Not all experts were familiar with supplement 


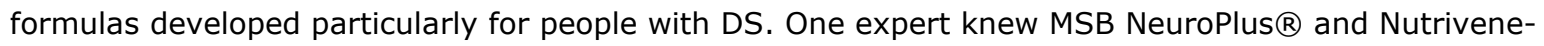
$D \circledR$, and indicated that MSB NeuroPlus ${ }^{\circledR}$ entails high levels of $B 1, B 6$ and $B 12$, which this expert thought was alarming. One expert knew Nutrivene- $D \&$, but indicated that only a few of his clients mentioned this specific supplement. Two experts conducted research themselves on the specific formulas for Down syndrome and they both found no significant evidence regarding the effectiveness of these supplements.

According to the manufacturer of MSB NeuroPlus ${ }^{\circledR}$, people with DS generally have several consistent nutritional issues like malabsorption of nutrients; increased oxidative stress and, therefore, an increased need for antioxidants; altered methylation pathways that affect the way folic acid, vitamin B12 and choline are utilized and many more issues like these. In addition, people with DS also have more general issues, such as vitamin D deficiencies, which are common in the general population of Canada (where the supplement is produced and sold). Moreover, there are additional deficiencies caused by feeding challenges in individuals with DS. Thus, nutritional deficiencies are known to have a higher prevalence among people with DS, which is also observed in the lab that MacLeod built to test the nutrient levels of children with DS. Furthermore, he finds it reasonable to provide multivitamins to children with DS, based on the observation that most typical developing individuals in the general population do not obtain sufficient nutrients from their diet. Providing a multivitamin can cover this issue. Moreover, he mentioned that there are studies in which the effectiveness of multivitamins is shown in children without DS. He finds it strange that a child without DS would be given a supplement with beneficial effects, and that this would not be provided to a child with DS.

\subsubsection{Similarities and differences in parents' and experts' viewpoints}

To summarize the findings, four out of the five interviewed parents provide (or used to provide) their child with dietary supplements, and they observed positive effects regarding health and cognitive functioning. The interviewed paediatricians and dieticians on the other hand have a clear preference for obtaining nutrients from the basic diet. They report that they base their advices on evidence-based guidelines, but one of them also takes practice-based theory into account. The manufacturer does find it reasonable to provide multivitamins to DS children, because they in general more often experience nutritional issues and deficiencies. Furthermore, it is observed that, in general population, most individuals do not obtain sufficient nutrients from their diet, and therefore he believes that everyone would need extra supplements.

There are no recommendations for dietary supplement use in clinical or dietary guidelines, since scientific evidence is lacking (except for vitamin D advice in specific cases, e.g. children 0-4 years). In case of deficiencies, supplementation can however be considered according to some of the experts. Parents base their decision on positive effects they notice in their child. When talking about dietary supplements with their medical experts, some parents feel neglected or disagree to the opinion of the expert and decide to supplement anyway. One of the experts indicated that if the parent still wishes to provide a supplement, he usually looks up information to check the safety. Another expert indicated, if parents are persistent in their wish for supplements, he would advise multivitamin supplements below recommended daily values. Especially doing research regarding safe doses seems important, since both parents and experts mentioned that indeed for some of the vitamins in the specific formulas, the concentrations can be high. In contrast, one parent trusts on the advice of the experts, and is therefore not giving supplements.

\subsubsection{Inventory of dietary supplements}

Two supplements targeted at people with DS were found through the online search of the ACT students: MSB NeuroPlus $\AA$ and Nutrivene- $D \circledast$. The students also included the supplement LTO3 in their report, as this supplement was mentioned by some parents, however the manufacturer is not making specific claims about people with DS and it is therefore left out of this comparison. The labels of both supplements are enclosed in Annex 5.

The main characteristics of MSB NeuroPlus $\AA$ and Nutrivene-D $®$ are displayed in Table 4. MSB NeuroPlus $\AA$ comes in powder or capsules and contains 36 different ingredients. Nutrivene-D $\cap$ comes in capsules and contains 41 different ingredients. Both supplements are from manufacturers outside 
of Nutrivene- $D \Re$, this comparison is made with the DV (daily value). These values are set by the FDA (U.S. Food and Drug Administration). It should be taken in to account that these reference intakes can differ in the US and Canada, as compared to recommendations in the Netherlands.

The ACT students made a comparison of the dosages of different ingredients in the MSB NeuroPlus $\mathbb{R}$ to the RDA, and they described that the B vitamins (B1, B2, B5, B6, B12) are present in higher dosage than the RDA. For Nutrivene- $D \AA$, the $D V$ is surpassed by many nutrients present in the supplement (vitamin C, D, E, K, B1, B2, B3, B6, folic acid, B12, biotin, d-calcium, zinc and chromium). Besides the RDA for each vitamin, there are also safe upper limits for some vitamins and minerals. In Europe the EFSA has established these 'upper tolerable intake levels' (UTLs) for the vitamins A, D, E, B3, B6 and folic acid and for the minerals calcium, magnesium, iodine, cupper, selenium and zinc for children and adults. The UTL is the maximum level of total chronic daily intake of a nutrient (from all sources) judged to be unlikely to pose a risk of adverse health effects to humans. 'Tolerable intake' in this context means what is physiologically tolerable and is a scientific judgement as determined by assessment of risk, i.e. the probability of an adverse effect occurring at some specified level of exposure. UTLs are derived for various age groups in the population. Supplementing vitamins and minerals above UTLs, can cause serious side effects [51]. The Netherlands Nutrition Center developed a factsheet with recommendations for vitamins and minerals per age category based on this EFSA information [52].

In Table 1 (for the MSB NeuroPlus $\AA$ supplement) and in Table 6 (for the Nutrivene-D $®$ supplement), a comparison was made for the vitamins and minerals in the formulas that have a upper tolerable limit (UTL), to see whether the safe upper limits that are in place in the Netherlands for children, are exceeded [53]. It has to be mentioned that only a few ingredients of the supplement (11 out of 36 for MSB NeuroPlus $\left({ }^{\circ}\right.$ and 10 out of 41 for Nutrivene-D $($ ) could be checked regarding the UTLS of EFSA, since not for all vitamins and minerals UTLs are known. For MSB NeuroPlus ${ }^{\circ}$, almost none of the known UTLs were exceeded. Only the recommended dosage for the age category 14 years and up, exceeds the UTL for vitamin B6 with $5 \mathrm{mg}$, as is visible in bold in Table 5. Exceeding the UTL of vitamin B6 can affect the nervous system, causing numbness, tingling or severe nerve pain in the hands and feet. This is called peripheral neuropathy [54].

\section{Table 5 Recommended doses of MSB NeuroPlus $®$ (based on age) as compared to daily Upper Tolerable Limits (U/s) for children (Netherlands Nutrition Centre). Dosages in bold are exceeding UTLs.}

\begin{tabular}{|c|c|c|c|c|c|c|c|c|c|}
\hline & $\begin{array}{l}\text { MSB } \\
\text { NeuroPlus@ } \\
2-3 \text { years } \\
(1 / 2 \text { scoop) }\end{array}$ & $\begin{array}{l}\mathbf{U T L}^{\mathbf{a}} \\
1-3 \text { years }\end{array}$ & $\begin{array}{l}\text { MSB } \\
\text { NeuroPlus } \\
\text { (B) } \\
4-8 \text { years } \\
\text { (1 scoop) }\end{array}$ & $\begin{array}{l}\mathbf{U T L}^{\mathbf{a}} \\
4-6 \text { years }\end{array}$ & $\begin{array}{l}\mathbf{U T L}^{\mathbf{a}} \\
7-10 \text { years }\end{array}$ & $\begin{array}{l}\text { MSB } \\
\text { Neuroplus } \\
\text { @ } \\
9-13 \text { years } \\
\text { (2 scoops) }\end{array}$ & $\begin{array}{l}\mathbf{U T L}^{\mathbf{a}} \\
11-14 \text { years }\end{array}$ & $\begin{array}{l}\text { MSB } \\
\text { Neuroplus } \\
\text { () } \\
14>\text { years } \\
\text { (4 scoops) }\end{array}$ & $\begin{array}{l}\mathbf{U T L}^{\mathbf{a}} \\
15-17 \\
\text { years }\end{array}$ \\
\hline Niacine, B3 & $0.63 \mathrm{mg}$ & $2 \mathrm{mg}$ & $1.25 \mathrm{mg}$ & $3 \mathrm{mg}$ & $4 \mathrm{mg}$ & $2.5 \mathrm{mg}$ & $6 \mathrm{mg}$ & $5 \mathrm{mg}$ & $8 \mathrm{mg}$ \\
\hline $\begin{array}{l}\text { Niacinamide } \\
\text { B3 }\end{array}$ & 8.63 & $150 \mathrm{mg}$ & $17.25 \mathrm{mg}$ & $220 \mathrm{mg}$ & $350 \mathrm{mg}$ & $34.5 \mathrm{mg}$ & $500 \mathrm{mg}$ & $69 \mathrm{mg}$ & $700 \mathrm{mg}$ \\
\hline Vitamin B6 & $3.1 \mathrm{mg}$ & $5 \mathrm{mg}$ & $6.25 \mathrm{mg}$ & $7 \mathrm{mg}$ & $10 \mathrm{mg}$ & $12.5 \mathrm{mg}$ & $15 \mathrm{mg}$ & $25 \mathrm{mg}$ & $20 \mathrm{mg}$ \\
\hline Vitamin $A^{c}$ & $56.3 \mathrm{mcg}$ & $800 \mathrm{mcg}$ & $112.6 \mathrm{mcg}$ & $1100 \mathrm{mcg}$ & $1500 \mathrm{mcg}$ & $225.2 \mathrm{mcg}$ & $2000 \mathrm{mcg}$ & $450.4 \mathrm{mcg}$ & $2600 \mathrm{mcg}$ \\
\hline Vitamin $\mathrm{D}^{\mathrm{c}}$ & $3.2 \mathrm{mcg}$ & $50 \mathrm{mcg}$ & $6.3 \mathrm{mcg}$ & $50 \mathrm{mcg}$ & $50 \mathrm{mcg}$ & $12.6 \mathrm{mcg}$ & $100 \mathrm{mcg}$ & $25.2 \mathrm{mcg}$ & $100 \mathrm{mcg}$ \\
\hline Vitamin $\mathrm{E}^{\mathrm{bc}}$ & $8.4 \mathrm{mg}$ & 100 mg & $16.8 \mathrm{mg}$ & $120 \mathrm{mg}$ & $160 \mathrm{mg}$ & $33.6 \mathrm{mg}$ & $220 \mathrm{mg}$ & $67.2 \mathrm{mg}$ & $260 \mathrm{mg}$ \\
\hline Magnesium & $22.5 \mathrm{mg}$ & - & $45 \mathrm{mg}$ & $250 \mathrm{mg}$ & $250 \mathrm{mg}$ & 90 mg & $250 \mathrm{mg}$ & $180 \mathrm{mg}$ & $250 \mathrm{mg}$ \\
\hline Iodine & $12.5 \mathrm{mcg}$ & $200 \mathrm{mcg}$ & $25 \mathrm{mcg}$ & $250 \mathrm{mcg}$ & $300 \mathrm{mcg}$ & $50 \mathrm{mcg}$ & $450 \mathrm{mcg}$ & $100 \mathrm{mcg}$ & $500 \mathrm{mcg}$ \\
\hline Copper & $0.1 \mathrm{mg}$ & $1 \mathrm{mg}$ & $0.2 \mathrm{mg}$ & $2 \mathrm{mg}$ & $3 \mathrm{mg}$ & $0.4 \mathrm{mcg}$ & $4 \mathrm{mg}$ & $0.8 \mathrm{mcg}$ & $4 \mathrm{mg}$ \\
\hline Selenium ${ }^{b}$ & $12.5 \mathrm{mcg}$ & $60 \mathrm{mcg}$ & $25 \mathrm{mcg}$ & $90 \mathrm{mcg}$ & $130 \mathrm{mcg}$ & $50 \mathrm{mcg}$ & $200 \mathrm{mcg}$ & $100 \mathrm{mcg}$ & $250 \mathrm{mcg}$ \\
\hline Zinc & $2.5 \mathrm{mg}$ & $7 \mathrm{mg}$ & $5 \mathrm{mg}$ & $10 \mathrm{mg}$ & $13 \mathrm{mg}$ & $10 \mathrm{mg}$ & $18 \mathrm{mg}$ & $20 \mathrm{mg}$ & $22 \mathrm{mg}$ \\
\hline
\end{tabular}

a Upper tolerable limit as defined by EFSA in 2006

b Vitamin E and Selenium UTL's have weak evidence according to the Netherlands Nutrition Centre

c Vitamin A, D, and E dosages were recalculated from IU (=International Units) to micrograms.

For the Nutrivene-D® supplement, recommendations regarding daily doses on the label could not be compared on the bases of age, since the serving sizes on the label are based on body weight.

Therefore, in Table 6, three example comparisons were made for: a girl with DS, 3 years of age with a 
body weight of $12 \mathrm{~kg}$, a girl with DS, 6 years of age with a body weight of 22 kilograms, and a girl with DS, 15 years of age with a body weight of $55 \mathrm{~kg}$ (based on TNO growth curves for children with Down syndrome, $S D=0$ for height and $S D=0$ for normative weight [55]). As is visible in bold in the table, the UTLs for vitamin B6 and zinc are exceeded in the comparisons based on body weight and age. For vitamin B6, the UTL's are exceeded in all three age categories, for zinc (slightly) in two age categories. As described above, too high doses of vitamin B6 can affect the nervous system [54]. Zinc is not stored in the body and excess intakes result in reduced absorption and increased excretion. Nevertheless, there are documented cases of acute and chronic zinc poisoning [51]. Furthermore, too high doses of zinc can cause a cupper deficiency, which in turn can lead to anemia, a lighter skin and osteoporosis [56].

Table 6 Recommended doses of Nutrivene-D® (based on body weight) compared to Upper Tolerable Limits (Uls) for three examples: a 3 year old girl with DS, 6 year old girl with DS and 15 year old girl with DS. Dosages in bold are exceeding UTLs.

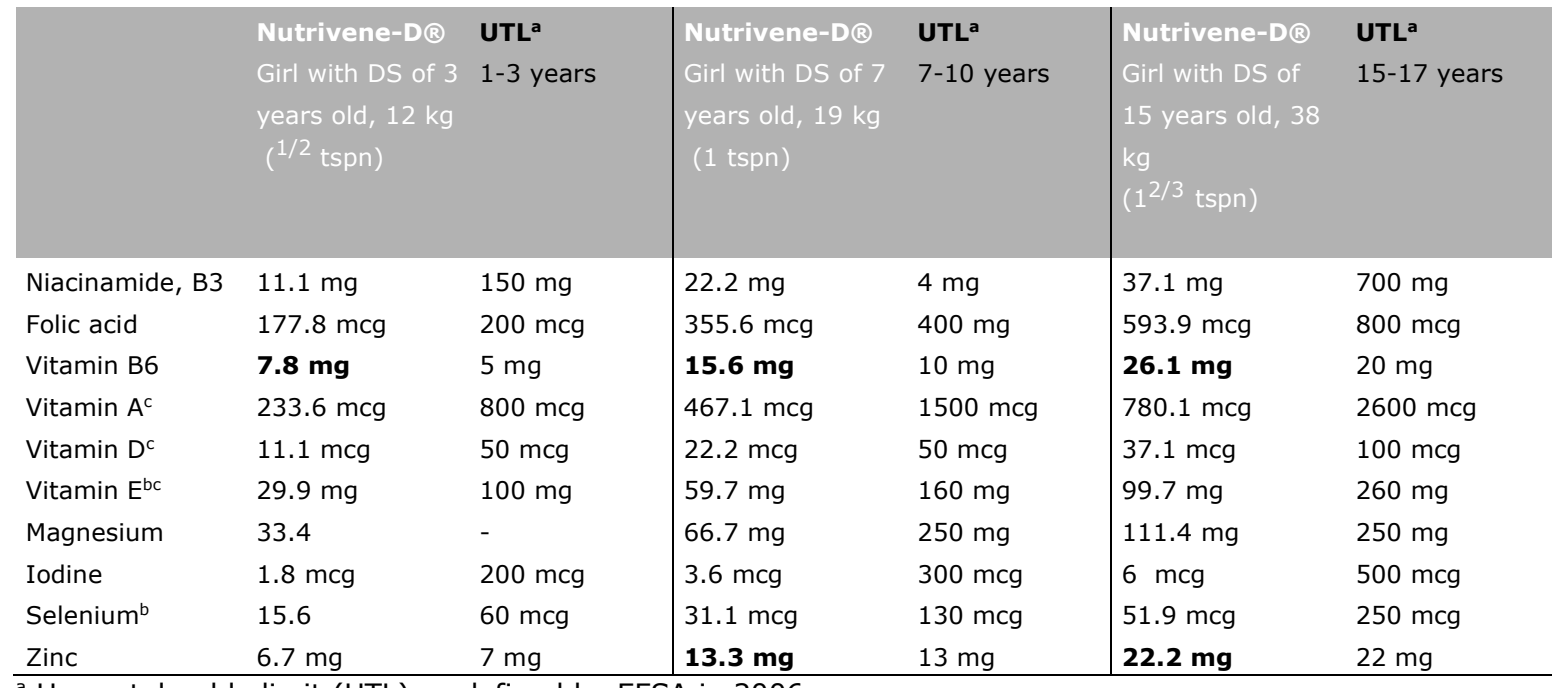

a Upper tolerable limit (UTL) as defined by EFSA in 2006

${ }^{b}$ Vitamin E and Selenium UTL's have weak evidence according to the Netherlands Nutrition Centre

${ }^{c}$ Vitamin A, D, and $E$ dosages were recalculated from IU (=International Units) to micrograms.

Besides these specific supplements for DS, the ACT-students also looked into three general multivitamins (Davitamon Junior 3-12, Davitamon Junior 3+ chewing tablets and Kruidvat multi A-Z $4+$ ) frequently mentioned in the survey that they conducted (see 3.1.1). Following the aforementioned European Regulation on dietary supplements [48], these supplements have EUallowed claims on their label regarding promoting and maintaining general health. In these supplements, all vitamins, mineral and trace elements are within the RDA, except for vitamin D (200\% of the RDA in both Davitamon multivitamins and $160 \%$ of the RDA in the Kruidvat multivitamin). Furthermore, the Kruidvat multivitamin exceeds the RDA for calcium (160\%) These dosages are however still within safe ranges.

\subsection{Literature study}

This chapter describes the results of the literature study, which aimed to investigate the scientific evidence for providing dietary supplements to children with DS. This literature study was carried out by two BSc students under supervision of professor Renger Witkamp (WU) and with input from Sandra van der Haar (WFBR). In addition, two scientists of WFBR (Sandra van der Haar and Gertrude Zeinstra) studied the available evidence for dietary supplements in children with DS. The final reports of both thesis-students plus the Excel file summarizing relevant trials (see method section 2.2) were used as input for this chapter. Paragraph 3.2.1 describes the scientific evidence for nutritional deficiencies in children with DS. In paragraph 3.2.2, the evidence from clinical studies for beneficial effects of dietary supplementation and the possible underlying mechanisms are discussed. 


\subsubsection{Nutritional deficiencies in children with DS}

As mentioned in the introduction of this report, deficiencies of certain micronutrients might occur more often in children with DS. Nutritional intake has an important role in determining the micronutrient status of individuals. However, only a few studies investigated the general dietary intake of children with DS [5]. The study of Magenis et al. (2018) reported a higher energy and carbohydrate intake, and a shorter duration of breastfeeding in 19 Brazilian children and adolescents with DS and adolescents ( $5-18$ years old) compared to matched controls [57]. According to the estimated average requirement (EAR) or adequate intake (AI), the children and adolescents with DS had a lower or the same frequency of insufficient intake of the vitamins B5, folic acid, and D, and the mineral calcium. However, the intake of sodium was excessive in both groups, especially in the DS group. Another study investigated the nutritional intake of children with DS in Saudi Arabia and their siblings ( $N=108$, aged 5-12 years). The authors found that the children with DS had significantly lower intakes than their siblings of fat, protein, vitamin A and B2, and potassium. The intake of the minerals calcium and sodium were also significantly lower in the children with DS [58]. Grammatikopoulou and colleagues (2008) observed an obviously higher energy intake in Greek teenagers with DS (aged 1018 years) compared to children with DS (aged 2-9 years). Overall, the children with DS in this study consumed healthier foods than the teenagers, as the children are more reliable on the food provision by their parents [42].

Several studies investigated more targeted if certain deficiencies occur more often in children with DS, which is discussed below per micronutrient. Also the relatively frequent use of medication in children with DS might possibly contribute to nutrient deficiencies due to drug-food interactions. These are discussed in 3.2.1.7.

\subsubsection{Zinc}

A recent review of Saghazadeh et al. (2017) which included thirty-one studies, indicated significantly lower blood levels of $\mathrm{Zn}$ in people with DS than in sex-matched healthy controls. Also plasma, serum and red blood cell $\mathrm{Zn}$ values were lower, but hair Zn levels were higher in people with DS [35]. A study of Grabeklis et al. (2020) in children with DS aged 7 to 15 years old, children with obesity, and children with a growth delay, reported that $14 \%$ of DS children had lower hair levels of $\mathrm{Zn}$ [59]. Lower $\mathrm{Zn}$ levels were also found in the other two groups of children, indicating that alteration of trace element and mineral status in DS shares certain similar features to other disorders including obesity and growth delay [59]. Furthermore, in a study of Lima et al (2010) significantly lower plasma and urine $\mathrm{Zn}$ concentrations were found in children with DS aged 4 to 11 years, compared to children without the condition. However, their zinc concentration in erythrocytes was higher and their zinc intake was adequate [60]. It has been shown that zinc deficiency might alter the immune functioning and could contribute to secondary immunodeficiency $[61,62]$. One example is the association between lower plasma zinc levels and the presence of celiac disease in children with DS. This was demonstrated in a study of Licastro and colleagues, who found that plasma zinc levels were lower in children with DS (age 3-15 years) with coeliac disease than in DS children without coeliac disease [61]. Even though a lower Zn status has been observed in several studies in children with DS, it is unclear whether this leads to immune defects and contributes to immunological abnormalities.

\subsubsection{Vitamin D}

Another micronutrient that might be deficient in children with DS is vitamin D. Vitamin D status can be classified as severely deficient, deficient, insufficient or sufficient when the serum concentration of $25(\mathrm{OH}) \mathrm{D}$ is $\leq 10,11-20,21-30$, or $>30 \mathrm{ng} / \mathrm{mL}$, respectively. These levels are established according to bone health. Children with DS and a deficit of vitamin D can be fragile to fractures and osteoporosis later in life. Furthermore, these children might be more susceptible to develop autoimmune diseases, since vitamin D probably has an important immune- regulatory function [34].

The study of Cheema et al investigated the association between bone profile and vitamin $D$ status in 5-11 years old children with an intellectual disability. The study included 61 children whereof 9 children had DS [63]. A below-normal bone profile was observed in $27.9 \%$ of all subjects (including also other intellectual disabilities) by quantitative ultrasound (QUS) and $85 \%$ had vitamin D levels below $20 \mathrm{ng} / \mathrm{mL}$. It has to be taken into account that only $15 \%$ of the study sample was diagnosed 
with DS, so the results might not be very specific for this group. Furthermore, the study did not take into account all the factors that contribute to vitamin D status like exposure to sunlight, and dietary intake and supplement use of vitamin D. Stagi et al. (2015) did include those factors into their study. They observed the risk of vitamin D deficiency in 31 DS subjects (age 4.5-18.9 years) compared to 99 age- and sex-matched healthy controls. At baseline, $16.1 \%$ of the 31 DS subjects had vitamin D insufficiency, $45.2 \%$ had deficiency and $32.2 \%$ had severe deficiency. The controls had a significantly lower prevalence of vitamin D deficiency. Especially DS subjects with obesity and DS subjects with a history of autoimmune diseases showed a significant reduction in serum 25(OH)D levels [34].

\subsubsection{Vitamin A}

Vitamin A deficiency (VAD) has negative effects on the immunological response and is associated with greater morbidity-mortality due to infections, interfering with the processes of child [64]. VAD seems to be more prevalent in children with DS according to the following two studies. Ferraz et al. (2021) observed a prevalence of 25.5\% VAD among 47 Brazilian children with DS aged 2.1-5.8 years [64]. VAD was defined as a serum retinol concentration of $\leq 70 \mu \mathrm{mol} / \mathrm{L}$. Another study found a VAD prevalence of $18.4 \%$ in 38 children with DS (aged 2-16 years) compared to a $4 \%$ prevalence in 50 controls [65].

\subsubsection{Iron}

Iron is the fourth micronutrient that is considered worth evaluating, since children with DS might be more susceptible to iron deficiency anaemia (IDA). IDA is caused by both a lack of iron and a lack of hemoglobin. In a cross-sectional study among 0-20 year old children and young adults with DS from Jewish and Arabic ethnicity, 8.1\% (12 out of 149) suffered from anaemia and that proportion increased with age. Only 38 of the subjects were tested for an iron deficiency with a prevalence of $50 \%$. The authors conclude that the prevalence of IDA in children with DS does not greatly differ from the general population. Nevertheless, children with DS and IDA might be more susceptible to the effects of anemia based on the fact that they already have DS-related deficits in motor and neurocognitive development [33]. A quite similar study investigated the prevalence of anaemia in 200 DS (aged 1-18 years old) by searching the electronic health record of South California. Of those children, $22.5 \%$ had anaemia. The prevalence of anaemia in children aged 1 to 5 years old was $18.7 \%$ compared to $3.2 \%$ in the general population of the same age based on the National Health and Nutrition Examination Survey. No further details were available, so the cause of anaemia was unclear. The authors recommend annual screening on anemia until the age of 18 years [66]. Two studies that investigated the concentration of hair elements did found a reduction of iron levels in children with DS compared to control values [59,67].

\subsubsection{Folic acid and vitamin B12}

DNA methylation is a mechanism that might contribute to the medical abnormalities seen in DS, including mental retardation and susceptibility to autoimmune diseases and recurrent infections [68]. The DNA methylation in individuals with DS might be affected through the one-carbon unit cycle, due to altered levels of folic acid, vitamin B12 and homocysteine (Hcy). Changes in DNA methylation might in turn affect the degeneration of the nervous system in people with DS. Therefore in a study of Song and colleagues (2015), the serum and plasma levels of the one-carbon unit cycle biomarkers folic acid, vitamin B12 and Hcy of 36 children with DS were compared to the levels of 40 healthy controls [69]. The results showed a significant decrease of vitamin B12 levels, whereas Hcy levels were significantly increased in DS subjects compared to controls. Folic acid and vitamin B12 levels of the children with DS decreased significantly with increasing age. Both DNA hypermethylation and hypomethylation were found in the DS subjects with vitamin B12 deficiency and hyperhomocysteinemia respectively. Thus, this study suggests that there might be a link between the one-carbon unit cycle and DNA methylation regarding to neuropathological alterations in people with DS [69]. Furthermore, it is hypothesized that DS is a metabolic disease, since biochemical alterations of fundamental pathways are present, like the folate cycle, Hcy-Met cycle and Hcy trans-sulfuration. Again Hcy and vitamin B12 are suggested to play a role in cognitive development. For example, vitamin B12 is involved in the synthesis of myelin and regeneration of nerves. Vitamin B12 and folate 
levels in turn also affect the Hcy level regulation since both Hcy and folate metabolism are part of the one-carbon cycle [70].

\subsubsection{Other minerals}

The levels of several other minerals were also investigated in children with DS (to a lesser extent). Grabeklis et al. found lower hair element concentrations of cobalt, copper, calcium, magnesium, chrome, vanadium, manganese and selenium in children with DS (age 7-15 years) compared with values of healthy controls. Jozefczuk et al (2017) observed normal to high levels of calcium, low to normal magnesium levels and varying results for copper in children with different mental retardations [67].

In addition to the deficiencies described in the paragraphs above, children with DS have a higher risk of celiac disease, which can in turn lead to malabsorption, causing deficiencies of calcium, vitamin D, iron, folate or vitamin B12 [32, 71].

\subsubsection{DS comorbidities and possible food-drug interactions}

Children with DS often suffer from multiple comorbidities as described previously. For this reason, drugs and other treatments are commonly indicated. These can by themselves affect the nutritional status of children with DS by influencing the availability or uptake of nutrients, or by changing the intestinal microbiota composition.

Constipation is common in children with DS, and laxatives can be prescribed in these cases if needed (lactulose or macrogol) [72]. If laxatives are taken for a longer time, this can result in an impaired absorption of lipid-soluble vitamins, because laxatives can probably decrease micelle formation and thereby cause malabsorption of lipids and the lipid-soluble vitamins: A, D, E and K [73]. Gastrooesophageal reflux disease (GORD) is also more common in children with DS. This is often treated with proton-pump inhibitors (PPI). Concerns are raised by parents and researchers about the longterm use of PPIs. Problems that could occur include hypochlorhydria (low levels of stomach acid) and hypergastrinaemia (an excess of gastrin in the blood), increased risk of infections, vitamin and mineral deficiencies, adverse bone health, food allergy and drug interactions [74]. PPIs are also associated with vitamin B12 deficiency in adults, since the drug interferes with the digestion and absorption mechanism of dietary protein-bound vitamin B12 in the stomach (intrinsic factor) [74]. Vitamin B12 deficiency might therefore also be a problem in children who frequently use acid-suppressive drugs, including children with DS.

Epilepsy is also frequently present in children with DS, with a prevalence of $6-8 \%$ in Western countries [21]. To treat epilepsy, anti-epileptic drugs are prescribed. It is known that children treated with these drugs can have problems with their bone health. These bone problems might be partly related to increased liver vitamin D breakdown and impaired calcium absorption. Several cohort studies found that the prevalence of vitamin D deficiency is indeed relatively high in children treated with antiepileptic drugs. However, these studies have been limited by a lack of stratification with regard to confounding factors such as nutritional intake and physical activity [75]. Therefore, at the present time strong evidence is lacking, but there remains concern that children with epilepsy are at risk of poor bone health and that vitamin $D$ therapy may be beneficial. Furthermore, anti-epileptic drugs can induce deficiencies of vitamin B6, B12 and folate [76, 77].

\subsubsection{Scientific evidence for beneficial effects of dietary supplements in DS}

In this paragraph, the evidence for beneficial effects of dietary supplements is described. Firstly, the results from (systematic) reviews are discussed in 3.2.2.1 and second, 19 clinical trials with varying dietary supplement interventions are described. Table 7 provides an overview of 19 clinical trials in DS children 0-18 years. Some of these trials overlap with the reviews discussed in 3.2.2.1. The studies are grouped according to supplement type, and subsequently on publication year (from most recent to older). In total, two clinical studies focused on calcium and vitamin D, one on zinc, nine on antioxidants, four on EGCG and two on mixtures of vitamins and minerals. 15 trials focused on biomarkers or health outcomes, 3 trials on cognitive outcomes and one trial on a combination of both outcomes. The study populations were ranging from newborns to adults of 34 years old. All studies, except for 
three studies on EGCG, were carried out in children under 18 years old. Sample sizes ranged from 16 to 288 participants with DS.

\subsubsection{Evidence from review papers}

A total of four reviews were found, three of them focusing on cognitive effects of supplements [78-80] and one focusing on both health and cognitive effects [5]. These reviews all concluded that there is no strong evidence for the use of dietary supplements in children with DS [5, 78-80]. The most recent review that we found is the review of Nordstrøm and colleagues (2020). In that review, eight intervention studies on dietary supplements in children with DS were included. The review did not find any data to support the use of dietary supplementation, except when deficiency is documented [5]. Additionally, an important limitation that was recognized in this review was that most of the studies include small samples size and did not include any clinical outcome measures (most of them measured blood markers). The authors concluded that there is a need for more research with larger study samples and the inclusion of control groups. Another recent review of Revilla \& Martinez (2020) studied the evidence for anti-oxidant therapies in reducing oxidative stress (OS), thereby preventing neurodegeneration and improving cognition in DS. The review included both pre-clinical and clinical studies, in adults and children. The authors concluded that several antioxidant molecules have been proven to be effective in preclinical studies of cell cultures and mouse models; however, clinical trials have failed to show evidence of the efficacy of different antioxidants to improve cognitive deficits in individuals with DS [79]. Furthermore, a systematic review of Salman and colleagues (2002) did not find any evidence that cognitive function or psychomotor development were improved by any combination supplement with vitamins or minerals in either children or adults with DS [80]. Roizen (2001) reviewed the evidence for complementary and alternative therapies for children with DS to enhance cognitive function, including dietary supplements. She concluded that there is a lack of welldesigned scientific studies on the use of alternative therapies in individuals with DS, including nutritional supplements [78].

\subsubsection{Vitamin $\mathrm{D}$ and calcium in relation to bone health}

In recent years, there is a growing interest in the bone mass and quality of people with DS, since there seems to be a higher risk of developing reduced bone-mass accrual and thereby fractures and osteoporosis [34]. Two studies investigated the effects of calcium and vitamin D supplementation in children with DS. Reza et al. 2015 investigated the effects of calcium and training on the development of bone density in 48 children with DS aged 7-12 years old over a period of 4 months [81]. The subjects were randomly assigned to four groups: exercise and calcium intake $(\mathrm{Ex}+\mathrm{Ca}+)$, calcium intake-no-exercise $(\mathrm{Ex}-\mathrm{Ca}+)$, exercise no-calcium intake (Ex+Ca-) and a control group non-exerciseno-calcium intake (Ex-Ca-). The training consisted of weight bearing exercises for 45 minutes, 3 times a week and the calcium intake was $500 \mathrm{ml}$ enriched cow milk with vitamin D and $200 \mathrm{mg}$ calcium per day. Bone mineral density (BMD) was determined by dual-energy X-ray absorptiometry. At baseline, age, BMD, dietary calcium and physical activity were similar among the subjects. It was shown that BMD improved in all groups, but the significantly largest increase was seen in the Ex+Ca+ group, suggesting a synergistic effect of weight bearing exercise and calcium intake. Moreover, the contribution to BMD was larger for exercise than for calcium intake. The effects that were observed in this study were induced by an intervention that equals the general recommendations for physical exercise and vitamin $\mathrm{D}$ and calcium intake from regular nutrition. 


\begin{tabular}{|c|c|c|c|c|c|c|c|c|}
\hline Author & $\begin{array}{l}\text { Type of } \\
\text { trial }\end{array}$ & Journal & $\begin{array}{l}\text { Study } \\
\text { population }\end{array}$ & $\begin{array}{l}\text { Control } \\
\text { group }\end{array}$ & Intervention & $\begin{array}{l}\text { Health outcome or } \\
\text { biomarker }\end{array}$ & Cognitive outcome & Results \\
\hline \multicolumn{9}{|c|}{ Vitamin D + calcium } \\
\hline $\begin{array}{l}\text { Reza et al., } 201 \\
{[81]}\end{array}$ & $R, C$ & $\begin{array}{l}\text { Research in } \\
\text { Developmental } \\
\text { disabilities, } \\
\text { impact factor } \\
1.63\end{array}$ & $\begin{array}{l}36 \text { children } \\
\text { with DS, 7-12 } \\
\text { years old }\end{array}$ & $\begin{array}{l}12 \text { children } \\
\text { with DS, } 7-12 \\
\text { years old }\end{array}$ & $\begin{array}{l}\text { 4-month intervention } \\
\text { with exercise ( } 45 \mathrm{~min} \\
\text { weight-bearing } \\
\text { activities } 3 \times \text { a week) } \\
\text { and calcium ( } 500 \mathrm{ml} \\
\text { cow's milk vit D } \\
\text { enriched). } 4 \text { groups : } \\
\text { Ex+Ca+, Ex-Ca+, } \\
\text { Ex+Ca- and control }\end{array}$ & $\begin{array}{l}\text { Bone Mineral Density } \\
\text { (BMD) of the right } \\
\text { proximal femoral neck } \\
\text { by dual-energy } x \text {-ray } \\
\text { absorptiometry (DEXA- } \\
\text { scan). }\end{array}$ & & $\begin{array}{l}\text { Significantly higher BMD in all groups; } \\
\text { combined exercise and calcium group: } \\
14.6 \% \text { increase; exercise group: } \\
8.6 \% \text { increase; calcium group: } 3.5 \% \\
\text { increase; no intervention: } 1.3 \% \\
\text { increase. }\end{array}$ \\
\hline $\begin{array}{l}\text { Stagi et al., } \\
2015 \text { [34] }\end{array}$ & $\mathrm{C}$ & $\begin{array}{l}\text { International } \\
\text { Journal of } \\
\text { Endocrinology, } \\
\text { impact factor } \\
2.29\end{array}$ & $\begin{array}{l}31 \text { children } \\
\text { with DS, } \\
4-19 \text { years old }\end{array}$ & $\begin{array}{l}99 \text { age- and } \\
\text { sex-matched } \\
\text { healthy } \\
\text { controls }\end{array}$ & $\begin{array}{l}10 \mu \mathrm{g} \text { oral } \\
\text { cholecalciferol for } 6 \\
\text { months }\end{array}$ & $\begin{array}{l}\text { Plasma } 25(\mathrm{OH}) \mathrm{D} \\
\text { levels, serum calcium } \\
\text { and phosphate, bone } \\
\text { specific alkaline } \\
\text { phosphate, and } \\
\text { parathyroid hormone; } \\
\text { evaluation of dietary } \\
\text { vitamin D intake by } \\
\text { interviews with } \\
\text { parents }\end{array}$ & & $\begin{array}{l}\text { Before intervention: significantly lower } \\
25(\mathrm{OH}) \mathrm{D} \text { levels in DS group than in } \\
\text { control group, especially in DS subjects } \\
\text { with obesity and autoimmune disease } \\
\text { history. After intervention: significantly } \\
\text { improved plasma } 25(\mathrm{OH}) \mathrm{D} \text { levels in } \\
\text { DS children, but still lower than control } \\
\text { group. Higher parathyroid hormone } \\
\text { levels in DS group than in control } \\
\text { group, both before and after } \\
\text { intervention. }\end{array}$ \\
\hline \multicolumn{9}{|c|}{ Zinc } \\
\hline $\begin{array}{l}\text { Marreiro et al., } \\
2008 \text { [82] }\end{array}$ & $\begin{array}{l}\text { One group, } \\
\text { pretest- } \\
\text { posttest }\end{array}$ & $\begin{array}{l}\text { Biological } \\
\text { Trace Element } \\
\text { Research, } \\
\text { impact factor } \\
2.43\end{array}$ & $\begin{array}{l}16 \text { children } \\
\text { with DS, 10-19 } \\
\text { years old }\end{array}$ & - & $\begin{array}{l}\text { Daily } 30 \mathrm{mg} \text { zinc, for } 4 \\
\text { weeks }\end{array}$ & $\begin{array}{l}\text { Zinc concentrations in } \\
\text { plasma and } \\
\text { erythrocytes and } \\
\text { serum concentrations } \\
\text { of thyroid hormone } \\
\text { levels } \\
\end{array}$ & & $\begin{array}{l}\text { Increased zinc concentration } \\
\text { in plasma and decreased } \\
\text { concentration in erythrocytes; no } \\
\text { difference in serum thyroid hormone } \\
\text { concentration. }\end{array}$ \\
\hline \multicolumn{9}{|c|}{ (Vitamins A, C, E, co- enzyme Q10, folate) } \\
\hline $\begin{array}{l}\text { Nachvak et al., } \\
2014 \text { [83] }\end{array}$ & $R, C$ & $\begin{array}{l}\text { European } \\
\text { Journal of } \\
\text { Clinical } \\
\text { Nutrition, } \\
\text { impact factor } \\
3.06\end{array}$ & $\begin{array}{l}93 \text { children } \\
\text { with DS, } \\
7-15 \text { years old }\end{array}$ & $\begin{array}{l}26 \text { controls } \\
\text { (non-DS } \\
\text { siblings) }\end{array}$ & $\begin{array}{l}\text { 4-month intervention } \\
\text { with anti-oxidants. } \\
\text { Group A: a-tocopherol } \\
\text { (266 mg/day) } \\
\text { Group B: a-lipoic acid } \\
\text { (100 mg/day) } \\
\text { Group C:placebo }\end{array}$ & $\begin{array}{l}\text { Oxidative stress } \\
\text { markers: serum } \\
\text { thiobarbituric acid } \\
\text { reactive substances } \\
\text { (TBARS) and urinary } \\
8 \text {-hydroxy-2 } \\
\text { deoxyguanosine } \\
(80 \mathrm{HdG}) \text {. }\end{array}$ & & $\begin{array}{l}\text { Serum levels of TBARS did not change } \\
\text { significantly over time, or relative to } \\
\text { placebo. Urinary } 80 H d G \text { concentrations } \\
\text { decreased significantly in both a- } \\
\text { tocopherol and ALA group compared } \\
\text { with the baseline levels. However, } \\
\text { mean final levels differed significantly } \\
\text { only between a-tocopherol and } \\
\text { placebo. }\end{array}$ \\
\hline
\end{tabular}




\begin{tabular}{|c|c|c|c|c|c|c|c|c|}
\hline Author & $\begin{array}{l}\text { Study } \\
\text { design }\end{array}$ & Journal & $\begin{array}{l}\text { Study } \\
\text { population }\end{array}$ & $\begin{array}{l}\text { Control } \\
\text { group }\end{array}$ & Intervention & $\begin{array}{l}\text { Health biomarker or } \\
\text { outcome }\end{array}$ & Cognitive outcome & Results \\
\hline $\begin{array}{l}\text { Parisotto et al., } \\
2014 \text { [84] } \\
\text { Parisotto et al., } \\
2015[85]\end{array}$ & C & \begin{tabular}{|l|} 
Research in \\
Developmental \\
disabilities, \\
impact factor \\
1.63
\end{tabular} & $\begin{array}{l}21 \text { children } \\
\text { with DS, } 3-14 \\
\text { years old }\end{array}$ & $\begin{array}{l}18 \text { healthy } \\
\text { controls, } 3-12 \\
\text { years old }\end{array}$ & $\begin{array}{l}6 \text { month intervention } \\
\text { with a daily dose of } \\
500 \mathrm{mg} \text { vitamin } \mathrm{C} \text { and } \\
400 \mathrm{mg} \text { vitamin } \mathrm{E} .\end{array}$ & $\begin{array}{l}\text { Antioxidant enzymatic } \\
\text { activity from whole } \\
\text { blood, haemolysates, } \\
\text { and in serum samples. }\end{array}$ & & $\begin{array}{l}\text { Significant differences in antioxidant } \\
\text { enzymatic activity between DS and } \\
\text { control group; more normalized } \\
\text { antioxidant enzymatic activity values in } \\
\text { DS group after intervention; increased } \\
\text { vitamin E levels in whole blood of DS } \\
\text { group. The second study (2015) } \\
\text { showed that these effects persisted for } \\
\text { at least } 6 \text { months after quitting the } \\
\text { antioxidant therapy. }\end{array}$ \\
\hline $\begin{array}{l}\text { Ellis et al., } 2008 \\
\text { [86] }\end{array}$ & $\mathrm{R}, \mathrm{DB}, \mathrm{C}$ & $\begin{array}{l}\text { British Medical } \\
\text { Journal, } \\
\text { impact factor } \\
39.9\end{array}$ & $\begin{array}{l}106 \text { infants } \\
\text { with DS under } \\
7 \text { months }\end{array}$ & $\begin{array}{l}33 \text { infants with } \\
\text { DS under } 7 \\
\text { months }\end{array}$ & $\begin{array}{l}18 \text { month intervention. } \\
\text { Group A: daily } \\
\text { antioxidants }(10 \mu \mathrm{g} \\
\text { selenium, } 5 \mathrm{mg} \text { zinc, } \\
0.9 \mathrm{mg} \text { vitamin } \mathrm{A}, 100 \\
\mathrm{mg} \text { vitamin } \mathrm{E} \text {, and } 50 \\
\mathrm{mg} \text { ascorbic acid) and } \\
0.1 \mathrm{mg} \text { folic acid. } \\
\text { Group B: antioxidants. } \\
\text { Group C: } 0.1 \mathrm{mg} \text { folic } \\
\text { acid Group D: placebo. }\end{array}$ & $\begin{array}{l}\text { Biochemical markers in } \\
\text { blood and urine at age } \\
12 \text { months. }\end{array}$ & $\begin{array}{l}\text { Griffiths } \\
\text { developmental } \\
\text { quotient and an } \\
\text { adapted MacArthur } \\
\text { communicative } \\
\text { development } \\
\text { inventory } 18 \text { months } \\
\text { after starting } \\
\text { supplementation }\end{array}$ & $\begin{array}{l}\text { Children randomized to antioxidant } \\
\text { supplements attained similar } \\
\text { developmental outcomes to those } \\
\text { without antioxidants. No significant } \\
\text { differences were found between any of } \\
\text { the groups in the biochemical } \\
\text { outcomes measured }\end{array}$ \\
\hline $\begin{array}{l}\text { Gualandri et al., } \\
2003 \text { [87] }\end{array}$ & $\begin{array}{l}\text { One group, } \\
\text { pretest- } \\
\text { posttest }\end{array}$ & \begin{tabular}{|l} 
International \\
Journal of \\
Clinical \\
Pharmacology \\
Research, \\
impact factor \\
0.93
\end{tabular} & $\begin{array}{l}33 \text { children } \\
\text { with DS, } 1-14 \\
\text { years. } 13 \\
\text { children } \\
\text { withdrew, so } \\
\text { results based } \\
\text { on } 20 \text { children. }\end{array}$ & - & $\begin{array}{l}30 \text { day intervention } \\
\text { with anti-oxidants: } \\
200 \mathrm{mg} \text { thioctic acid } \\
\text { and } 200 \mathrm{mg} \text { cysteine. }\end{array}$ & $\begin{array}{l}\text { Parameters indicative } \\
\text { of oxidative stress in } \\
\text { DS: thiol groups, } \\
\text { septic reactive oxygen } \\
\text { species and total } \\
\text { antioxidant } \\
\text { status in serum. }\end{array}$ & & $\begin{array}{l}\text { Significant increase in serum thiol } \\
\text { groups and antioxidant capacity in } \\
\text { serum; significant decrease in serum } \\
\text { total and septic reactive oxygen } \\
\text { species. }\end{array}$ \\
\hline $\begin{array}{l}\text { Larsen et al., } \\
2018 \text { [88] }\end{array}$ & C & $\begin{array}{l}\text { Neurobiology } \\
\text { of Aging, } \\
\text { impact factor } \\
4.4\end{array}$ & $\begin{array}{l}32 \text { children } \\
\text { with DS, } \\
2-17 \text { years old }\end{array}$ & $\begin{array}{l}14 \text { age- } \\
\text { matched } \\
\text { controls with } \\
\text { DS }\end{array}$ & $\begin{array}{l}\text { 4-year intervention } \\
\text { with } 4 \mathrm{mg} / \mathrm{kg} / \mathrm{d} \\
\text { CoQ10, in the form of } \\
\text { ubiquinone. Control } \\
\text { group received no } \\
\text { treatment. }\end{array}$ & $\begin{array}{l}\text { Urinary excretion of 8- } \\
\text { oxodG and 8-oxoGuo. } \\
\text { DNA oxidation in } \\
\text { peripheral blood } \\
\text { mononuclear cells at } 2 \\
\text { and } 4 \text { years. }\end{array}$ & & $\begin{array}{l}\text { Long-term (i.e., } 4 \text { years) treatment } \\
\text { with coenzyme } \mathrm{Q} 10 \text { (ubiquinone) at } \\
\text { the dosage of } 4 \mathrm{mg} / \mathrm{kg} / \mathrm{d} \text { does not } \\
\text { affect whole body DNA and RNA } \\
\text { oxidation. }\end{array}$ \\
\hline
\end{tabular}




\begin{tabular}{|c|c|c|c|c|c|c|c|c|}
\hline Author & $\begin{array}{l}\text { Study } \\
\text { design }\end{array}$ & Journal & $\begin{array}{l}\text { Study } \\
\text { population }\end{array}$ & $\begin{array}{l}\text { Control } \\
\text { group }\end{array}$ & Intervention & $\begin{array}{l}\text { Health biomarker or } \\
\text { outcome }\end{array}$ & Cognitive outcome & Results \\
\hline $\begin{array}{l}\text { Tiano et al., } \\
2012 \text { [89] }\end{array}$ & $\begin{array}{l}\text { One group, } \\
\text { pretest- } \\
\text { posttest }\end{array}$ & $\begin{array}{l}\text { Neurobiology } \\
\text { of Aging, } \\
\text { impact factor } \\
4.4\end{array}$ & $\begin{array}{l}28 \text { pediatric } \\
\text { patients with } \\
\text { DS, 5-17 years } \\
\text { old }\end{array}$ & - & \begin{tabular}{|l|}
20 month intervention \\
with CoQ10 \\
(mitoquinone) at doses \\
$4 \mathrm{mg} / \mathrm{kg} /$ day. \\
\\
\end{tabular} & $\begin{array}{l}\text { Plasma and cellular } \\
\text { CoQ10 levels, uricemia } \\
\text { and plasma allantoin } \\
\text { levels, antioxidant } \\
\text { activity (plasma } \\
\text { oxygen radical } \\
\text { absorbing } \\
\text { capacity)/oxidative } \\
\text { DNA damage in } \\
\text { lymphocytes }\end{array}$ & & $\begin{array}{l}\text { Significant rise in plasma CoQ10 } \\
\text { levels, not associated with any } \\
\text { variations in the considered } \\
\text { plasma oxidative stress-related indexes } \\
\text { (ORAC and allantoin levels). Age- } \\
\text { specific reduction in the percentage of } \\
\text { cells showing the highest amount of } \\
\text { oxidized bases, indicating a potential } \\
\text { role of CoQ10 in modulating DNA } \\
\text { repair mechanisms. }\end{array}$ \\
\hline $\begin{array}{l}\text { Tiano et al., } \\
2011 \text { [90] }\end{array}$ & $R, D B, C$ & $\begin{array}{l}\text { Neurobiology } \\
\text { of Aging, } \\
\text { impact factor } \\
4.4\end{array}$ & $\begin{array}{l}16 \text { pediatric } \\
\text { patients with } \\
\text { DS, 3-15 years } \\
\text { old }\end{array}$ & $\begin{array}{l}14 \text { controls } \\
\text { with DS }\end{array}$ & $\begin{array}{l}\text { DS children: 6-month } \\
\text { intervention of } 4 \\
\mathrm{mg} / \mathrm{kg} / \text { day of } \\
\text { ubiquinon-10 } \\
\text { (coenzyme Q10), } \\
\text { compared to a placebo } \\
\text { for the control group. }\end{array}$ & $\begin{array}{l}\text { CoQ10 plasma levels } \\
\text { and DNA oxidative } \\
\text { damage assessed at } \\
\text { baseline, } 1,3 \text { and } 6 \\
\text { months. }\end{array}$ & & $\begin{array}{l}\text { Significant rise in CoQ10 plasma levels } \\
\text { in } 1 \text { month in the intervention group } \\
\text { compared to controls (and these } \\
\text { remained high). Increased oxidative } \\
\text { damage to DNA in the studied patients } \\
\text { compared to matched healthy controls } \\
\text { of same age. No significant differences } \\
\text { in DNA damage between groups (were } \\
\text { similar at all time points). }\end{array}$ \\
\hline $\begin{array}{l}\text { Miles et al., } 2007 \\
{[91]}\end{array}$ & C & \begin{tabular}{|l|} 
Pediatric \\
Neurology, \\
impact factor \\
2.4
\end{tabular} & \begin{tabular}{|l|}
14 children \\
with DS, \\
$8-12$ years old
\end{tabular} & $\begin{array}{l}12 \text { healthy } \\
\text { historical } \\
\text { controls }\end{array}$ & $\begin{array}{l}\text { 3-months ubiquinol-10 } \\
\text { supplementation } 10 \\
\mathrm{mg} / \mathrm{kg} / \text { day }\end{array}$ & Plasma CoQ10 levels & & $\begin{array}{l}\text { Children with DS had sign. increased } \\
\text { plasma CoQ10 levels compared with } \\
\text { controls. After } 3 \text { months of ubiquinol- } \\
10 \text { supplementation, the mean } \\
\text { ubiquinol-10: total coenzyme Q10 ratio } \\
\text { increased significantly (meaning a } \\
\text { normalization of these levels). }\end{array}$ \\
\hline $\begin{array}{l}\text { Blehaut et al., } \\
2010 \text { [92] }\end{array}$ & $\mathrm{R}, \mathrm{DB}, \mathrm{C}$ & $\begin{array}{l}\text { PloS ONE, } \\
\text { impact factor } \\
3.24\end{array}$ & $\begin{array}{l}58 \text { children } \\
\text { with DS, } \\
3-30 \text { months } \\
\text { old }\end{array}$ & $\begin{array}{l}59 \text { children } \\
\text { with DS, } \\
3-30 \text { months } \\
\text { old }\end{array}$ & $\begin{array}{l}\text { Daily dose of } 1-0.3 \\
\mathrm{mg} / \mathrm{kg} \text { for } 12 \text { months. } \\
\text { They received } 1 \mathrm{mg} / \mathrm{kg} \\
\text { leucovorin or placebo } \\
\text { daily. Folinic acid } \\
\text { (leucovorin, } \mathrm{LV} \text { ) was } \\
\text { preferred to folic acid } \\
\text { as its bioavailability is } \\
\text { higher. }\end{array}$ & & $\begin{array}{l}\text { The developmental } \\
\text { age (DA) of the } \\
\text { patients was } \\
\text { assessed on the } \\
\text { Brunet-Lezine scale, } \\
\text { from baseline to the } \\
\text { end of treatment. }\end{array}$ & $\begin{array}{l}\text { Improvement of psychomotor } \\
\text { development. No effect on sociability, } \\
\text { language or coordination. }\end{array}$ \\
\hline
\end{tabular}




\begin{tabular}{|c|c|c|c|c|c|c|c|c|}
\hline Author & $\begin{array}{l}\text { Study } \\
\text { design }\end{array}$ & Journal & $\begin{array}{l}\text { Study } \\
\text { population }\end{array}$ & $\begin{array}{l}\text { Control } \\
\text { group }\end{array}$ & Intervention & $\begin{array}{l}\text { Health biomarker or } \\
\text { outcome }\end{array}$ & Cognitive outcome & Results \\
\hline & & & & & \multicolumn{4}{|c|}{ 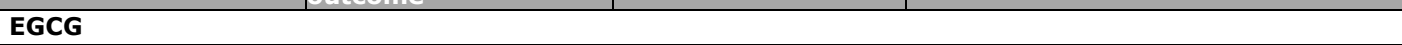 } \\
\hline $\begin{array}{l}\text { Xicota et al., } \\
2020[93]\end{array}$ & $R, D B, C$ & \begin{tabular}{|l} 
Clinical \\
Nutrition, \\
impact factor \\
6.77
\end{tabular} & $\begin{array}{l}40 \text { young } \\
\text { adults with DS, } \\
16-34 \text { years } \\
\text { old }\end{array}$ & $\begin{array}{l}37 \text { young } \\
\text { adults with DS, } \\
16-34 \text { years } \\
\text { old }\end{array}$ & $\begin{array}{l}\text { 12-month intervention } \\
\text { with EGCG }(9 \mathrm{mg} / \mathrm{kg})+ \\
\text { cognitive training. } \\
\text { Placebo group: } \\
\text { placebo capsules }+ \\
\text { cognitive training. 6- } \\
\text { months follow-up. }\end{array}$ & $\begin{array}{l}\text { Body mass index } \\
\text { (BMI), plasma lipid } \\
\text { (oxidize LDL } \\
\text { concentration in } \\
\text { plasma). }\end{array}$ & & $\begin{array}{l}\text { Individuals receiving placebo showed } \\
\text { an increase in body weight and body } \\
\text { mass index (BMI) that was not } \\
\text { detected in those with EGCG } \\
\text { treatment. EGCG effect on body } \\
\text { composition was mainly observed in } \\
\text { males, with significant lower weight } \\
\text { and body fat for the EGCG than the } \\
\text { placebo group after } 12 \text { months for } \\
\text { weight. The changes detected in body } \\
\text { composition were associated with } \\
\text { changes in lipid profile. }\end{array}$ \\
\hline $\begin{array}{l}\text { De la Torre et } \\
\text { al., } 2016[94]\end{array}$ & $\mathrm{R}, \mathrm{DB}, \mathrm{C}$ & \begin{tabular}{|l} 
The Lancet \\
Neurology, \\
impact factor \\
44.18 \\
\end{tabular} & \begin{tabular}{|l|}
43 young \\
adults with DS, \\
$16-34$ years \\
old \\
\end{tabular} & \begin{tabular}{|l|}
41 young \\
adults with DS, \\
$16-34$ years \\
old \\
\end{tabular} & \begin{tabular}{|l|} 
EGCG $9 \mathrm{mg} / \mathrm{kg} /$ day + \\
cognitive training vs. \\
placebo + cognitive \\
training for 12 months \\
\end{tabular} & & $\begin{array}{l}\text { Memory recognition, } \\
\text { working memory and } \\
\text { quality of life. }\end{array}$ & $\begin{array}{l}\text { Improvement in visual recognition } \\
\text { memory, inhibitory control, and } \\
\text { adaptive behavior. }\end{array}$ \\
\hline \multirow[t]{2}{*}{$\begin{array}{l}\text { De la Torre et } \\
\text { al., } 2014 \text { [95] }\end{array}$} & $\begin{array}{l}R, D B, C \\
\text { (pilot study) }\end{array}$ & \begin{tabular}{|l|} 
Molecular \\
Nutrition Food \\
Research, \\
impact factor \\
4.65 \\
\end{tabular} & $\begin{array}{l}15 \text { young } \\
\text { adults with DS, } \\
14-29 \text { years } \\
\text { old }\end{array}$ & $\begin{array}{l}16 \text { young } \\
\text { adults with DS, } \\
14-29 \text { years } \\
\text { old }\end{array}$ & $\begin{array}{l}\text { EGCG } 9 \mathrm{mg} / \mathrm{kg} / \text { day vs. } \\
\text { placebo for } 6 \text { months }\end{array}$ & & $\begin{array}{l}\text { Visual recognition } \\
\text { memory, inhibitory } \\
\text { control, and adaptive } \\
\text { behavior. }\end{array}$ & $\begin{array}{l}\text { Positive effects on memory recognition, } \\
\text { working memory, and quality of life. }\end{array}$ \\
\hline & & & & & $\begin{array}{l}\text { Mixture vitamins } \\
\text { and minerals }\end{array}$ & & & \\
\hline $\begin{array}{l}\text { Meguid et al., } \\
2015[96]\end{array}$ & C & $\begin{array}{l}\text { Journal of } \\
\text { Chemical and } \\
\text { Pharmaceutical } \\
\text { Research, } \\
\text { impact factor } \\
0.14\end{array}$ & $\begin{array}{l}21 \text { children } \\
\text { with DS, } 1 \\
\text { month to } 5 \\
\text { years old }\end{array}$ & $\begin{array}{l}20 \text { healthy } \\
\text { matched } \\
\text { controls }\end{array}$ & $\begin{array}{l}6 \text { month intervention } \\
\text { with mixture of daily } \\
\text { nutritional } \\
\text { supplements (Formula } \\
\text { X): consisted of three } \\
\text { parts, a daily } \\
\text { supplement containing } \\
\text { (vitamins, minerals, } \\
\text { amino acids and } \\
\text { related substances, an } \\
\text { enzyme supplement, } \\
\text { and a night-time } \\
\text { supplement. Dosage } \\
\text { based on body weight. } \\
\text { Controls received } \\
\text { placebo. }\end{array}$ & $\begin{array}{l}\text { Anti-oxidants } \\
\text { (glutathione (GSH)), } \\
\text { and anti-oxidant } \\
\text { enzyme activity (SOD, } \\
\text { GPx, CAT, GR and } \\
\text { GST). }\end{array}$ & & $\begin{array}{l}\text { Before supplementation, GSH and GST } \\
\text { levels were significantly low in DS } \\
\text { children, while SOD levels were } \\
\text { significantly high compared to controls. } \\
\text { After } 6 \text { months, significantly higher } \\
\text { levels were observed in the activity of } \\
\text { GPx and CAT with elevated GPx/GR } \\
\text { ratio and reduced SOD/(CAT + GPX) } \\
\text { ratio among DS children. } \\
\text { Supplementation of DS children with } \\
\text { formula X may protect against harmful } \\
\text { oxidative damage. }\end{array}$ \\
\hline
\end{tabular}




\begin{tabular}{|c|c|c|c|c|c|c|c|c|}
\hline Author & $\begin{array}{l}\text { Study } \\
\text { design }\end{array}$ & Journal & $\begin{array}{l}\text { Study } \\
\text { population }\end{array}$ & $\begin{array}{l}\text { Control } \\
\text { group }\end{array}$ & Intervention & $\begin{array}{l}\text { Health biomarker or } \\
\text { outcome }\end{array}$ & Cognitive outcome & Results \\
\hline $\begin{array}{l}\text { Lakshmi et al., } \\
2008 \text { [97] }\end{array}$ & $\begin{array}{l}\text { C } \\
\text { (pilot study) }\end{array}$ & \begin{tabular}{|l|} 
Singapore \\
Medical \\
Journal, \\
impact factor \\
1.14
\end{tabular} & $\begin{array}{l}40 \text { children } \\
\text { with DS aged } \\
\text { between } 5 \text { and } \\
16 \text { years old }\end{array}$ & $\begin{array}{l}40 \text { age- and } \\
\text { sex matched } \\
\text { healthy } \\
\text { controls }\end{array}$ & $\begin{array}{l}\text { DS children received a } \\
6 \text {-month intervention } \\
\text { with a nutritional } \\
\text { supplement containing } \\
1 \mathrm{mg} / \mathrm{kg} \text { bodyweight } \\
\text { zinc, } 1.5 \mathrm{mg} \text { vitamin } \\
\mathrm{A}, 17 \mathrm{mg} \text { vitamin } \mathrm{E}, \\
100 \mathrm{mg} \text { ascorbic acid, } \\
10 \mathrm{mg} \text { thiamine, } 10 \\
\mathrm{mg} \text { riboflavin, } 3 \mathrm{mg} \\
\text { pyroxidine, } 5 \mu \mathrm{g} \\
\text { cyanocobalamin, } 50 \\
\mathrm{mg} \text { nicotinic acid, } 1 \\
\mathrm{mg} \text { folic acid, } 12.5 \mathrm{mg} \\
\text { calcium pantothenate, } \\
2.5 \mathrm{mg} \text { copper, } 60 \mu \mathrm{g} \\
\text { selenium, } 1.4 \mathrm{mg} \\
\text { manganese, and } 5 \mu \mathrm{g} \\
\text { chromium }\end{array}$ & $\begin{array}{l}\text { Serum } \\
\text { acetylcholinesterase } \\
\text { and } \\
\text { butyrylcholinesterase }\end{array}$ & & $\begin{array}{l}\text { Significantly increased and more } \\
\text { normalised values of } \\
\text { acetylcholinesterase and } \\
\text { butyrylcholinesterase after } 6 \text { months in } \\
\text { DS group than in control group (DS } \\
\text { group started with lower baseline } \\
\text { values). }\end{array}$ \\
\hline
\end{tabular}

$\mathrm{R}=$ randomized, $\mathrm{DB}=$ double-blind, $\mathrm{C}$-controlled 
The study indicates that adherence to these recommendations is sufficient to obtain positive effects on bone health in children with DS.

Stagi et al. (2015) stress the importance of adequate levels of vitamin D and in their sample of 31 children with DS, they found that hypovitaminosis D was very frequent. The purpose of their intervention was to evaluate whether a normal 25(OH)D value could be restored by a daily supplement of $10 \mu \mathrm{g}$ oral cholecalciferol in $31 \mathrm{DS}$ children with reduced 25(OH)D levels. The results showed that after 6 months of supplementation the DS subjects had significantly higher levels of serum concentration of 25-hydroxyvitamin D 25(OH)D) as compared to baseline [34]. The effect was positive but inadequate, since $25(\mathrm{OH}) \mathrm{D}$ levels in these DS children were still lower by the end of the study compared to the control group. The study stresses the importance of adequate vitamin D intake to prevent low vitamin $\mathrm{D}$ status and that adherence to general recommendations might be inadequate in children with DS who already have a deficiency.

\subsubsection{Zinc in relation to thyroid metabolism}

It is proposed that zinc metabolism is altered in the presence of DS, and that zinc has a relationship with the metabolic alterations present in DS [60]. Zinc contributes to this hormone metabolism as a cofactor of deiodeinase type II, which regulates, together with other enzymes, the conversion of thyroxine (T4) to the active form triiodothyronine (T3) [82]. Therefore, thyroid metabolism in children with DS could perhaps be positively affected by the intake of a zinc supplement. One trial investigating the effects of zinc supplementation on thyroid hormone metabolism in children with DS was found. Marreiro and colleagues (2008) performed an intervention study with 16 DS subjects aged 10-19 years old [82]. They received $30 \mathrm{mg}$ zinc daily over a period of 4 weeks, and their diet was evaluated for 3 days to assess the zinc concentrations present in their diets. At the end of the intervention, the mean plasma zinc concentrations had increased significantly and zinc levels measured in erythrocyte were significantly decreased. There was however no significant difference in serum thyroid hormone concentration. The intervention with zinc showed to be effective in the stabilization of the concentrations of this mineral in plasma and erythrocytes, but had no influence on the metabolism of thyroid hormones [82].

\subsubsection{Anti-oxidants in relation to oxidative stress and cognitive functioning}

Oxidative stress is defined as a disturbance in the balance between the production of reactive oxygen species (free radicals) and antioxidant defenses in the body. It is proposed that DS is characterized by elevated oxidative stress levels. Several studies have shown these altered oxidative stress levels in children and teenagers with DS [98]. Oxidative DNA damage has been linked to neurodegeneration in DS [90]. Ani and colleagues (2000) found that there is reasonably strong evidence for increased oxidative stress in DS, and that there are several theoretical bases, namely: a gene dose overexpression of superoxide dismutase (SOD) increased lipid peroxidation in human individuals with DS and transgenic mice models, compensatory increases in GSH-Px and HMPS activities, increased products of oxidative DNA damage, increased chromosomal damage reduced by $50 \%$ in vitro by the addition of vitamin $E$, and increased intracellular free radicals and enhanced apoptosis in neurons of fetuses with DS which can be prevented by addition of antioxidants [99]. According to Garlet et al (2013) SOD-levels are increased in $47 \%$ of children and teenagers with DS [98]. Therefore, there is good evidence that increased oxidative stress may play a role in the complications of DS, such as immune dysfunction, malignancy, mental development and premature ageing. Revilla and colleagues (2020) found that several antioxidant molecules have been proven to be effective in preclinical studies of cell cultures and DS mouse models [79]. The hypothesis is therefore that supplementation with increased amounts of antioxidant nutrients could benefit individuals with DS [83, 99].

A total of 9 clinical trials were found, investigating the effects of several antioxidant supplements in children with DS. Nachvak et al. (2014) studied the effects of either $266 \mathrm{mg}$ of a-tocopherol (vitamin E) per day, $100 \mathrm{mg}$ a-lipoic acid per day or a placebo in 93 DS children of 7-15 years old [83]. The outcome measures included oxidative stress markers: serum thiobarbituric acid reactive substance (TBARS) and urinary 8-hydroxy-2-deoxyguanosine (8-OHdG). At baseline, the levels of oxidative stress biomarkers in the children with DS were significantly higher than their non-DS siblings. After the intervention, TBARS serum concentrations had not significantly changed compared to baseline levels. However, the urinary 8-OHdG levels did decrease significantly over time in the DS groups who 
received a-tocopherol or thioctic acid. The difference in mean final concentrations of urinary $80-\mathrm{OHdG}$ was only significant between the a-tocopherol and the placebo group. Thus, oxidative damage to DNA in children with DS might be reduced by using $266 \mathrm{mg}$ a-tocopherol for 4 months, as concluded by this study. However, only oxidative stress markers in blood were assessed and not actual cognitive development.

Parisotto and colleagues (2014) describe that oxidative stress is part of the fundamental biology of DS, and that it has been suggested that the main source of reactive oxygen species (ROS) in people with DS is the excessive production of hydrogen peroxide ( $\mathrm{H} 2 \mathrm{O} 2)$ through the action of $\mathrm{Cu}, \mathrm{Zn}-\mathrm{SOD}$ dismutase [84]. As a result of the overrepresentation of $\mathrm{Cu}, \mathrm{Zn}-\mathrm{SOD}$, an imbalance with other antioxidant enzymes occurs, inducing a systemic oxidative damage. Therefore, antioxidant supplementation would attenuate biomarkers of oxidative stress and the aim of the trial was to compare anti-oxidant status in blood of DS children, before and after 6 months of daily antioxidant supplementation with a dose of $500 \mathrm{mg}$ of vitamin C and $400 \mathrm{mg}$ of vitamin E. Antioxidant enzymatic activity from whole blood, haemolysates, and in serum samples were assessed at baseline and after 6 months. The results showed that oxidative damage (assessed by measuring several oxidative stress markers in blood) was significantly improved due to supplementation. A subsequent study of Parisotto et al published in 2015 showed that these differences in antioxidants enzymatic activity between DS and the control group persisted at least 6 months after cessation of the antioxidant therapy [85]. Parisotto et al propose a possible positive effect of these improvements on cognitive functioning. This has not yet been studied in people with DS, but it was shown in a mouse study of Lockrow [100].

The randomized controlled trial carried out by Ellis and colleagues (2008) had a stricter study design than most other studies on this topic and was published in a reputable journal with a high impact factor and included a large sample; 156 DS infants with a mean age of 4 months at enrolment. The researchers investigated the effect of an orally supplemented mixture of antioxidants (selenium, zinc, vitamin A, vitamin E and vitamin C) and/or folic acid for 18 months. The results showed no improvements in oxidative stress, which was biochemically measured, or in cognitive functions, which were measured by the development of major motor milestones and language development [101]. The authors suggest that the lack of beneficial effects could be due to the relatively low dose of the supplements (similar to the RDA) or the short duration of the treatment (18 months).

A study of Blehaut et al. (2010) in which folate was supplemented at high doses to 117 children with DS aged between 3 and 30 months, showed that psychomotor development was slightly improved, but sociability, language, or coordination were not changed [92].

A specific antioxidant often proposed for children with DS is Coenzyme Q10 (CoQ10), also known as ubiquinol-10. This lipophilic antioxidant is suggested to inhibit DNA oxidation and thereby DNA damage. The study of Miles et al. (2007) was the first study that investigated this relationship [91]. Fourteen children with DS received ubiquinol-10 (10 mg/kg/day) supplements for 3 months. After the treatment, the mean ubiquinol-10:total CoQ10 ratio had significantly increased above baseline values, meaning a normalization of those values. Subsequent studies of Tiano and colleagues (2011 and 2012) reported a significant increase in plasma CoQ10 levels in children with DS after prolonged treatment with CoQ10 (4 mg/kg/day) for 6 and 20 months respectively [89, 90]. However, both studies were not able to detect beneficial effects on DNA damage, although the 20 month trial did find an age-specific reduction in the percentage of cells showing the highest amount of oxidized biases, indicating a potential role of CoQ10 in modulating DNA repair mechanisms. Later, a comparable study was performed by Larsen et al (2018) where the effect of long-term treatment with CoQ10 on DNA and RNA oxidation was investigated [88]. In this study, 30 children with DS were randomly allocated to an intervention and placebo group. The intervention group received $4 \mathrm{mg} / \mathrm{kg} / \mathrm{day}$ CoQ10 in the form of ubiquinone for 4 years and the level of DNA oxidation was measured by 8-oxo-7,8-dihydro-2'deoxyguanosine (8-oxodG) and 8-oxo-7,8-dihydroguanosine (8-oxoGuo) levels. No significant effect of 4-year treatment with CoQ10 on whole body DNA and RNA oxidation was found in this study.

To summarize, even though some of the aforementioned studies did show effects of antioxidant supplementation on reduction of oxidative stress levels in DS children, there were only two trials investigating the effects on cognitive functioning, showing no effects [86] and only a small effect on one aspect related to cognitive functioning [92]. 


\subsubsection{EGCG in relation to cognitive functioning, facial shape and body weight}

Epigallocatechin-3-gallate (EGCG) is the major polyphenol (50-75\%) found in green tea extracts (GTE) [44]. EGCG has many properties that are proposed to be beneficial for individuals with DS. It directly regulates and interacts with proteins involved in all kinds of physiological process in the body, such as cell membrane integrity, signal transduction, transcription factors, DNA methylation, phosphorylation, mitochondrial function and autophagy [102]. The administration of green tea extracts containing EGCG is proposed to have several beneficial effects on cognitive functions, body weight and even facial dysmorphologies associated with DS.

Several studies on effects of EGCG in mouse models of Down syndrome were performed, focusing on different outcomes. EGCG has been found to be an inhibitor of Dual Specificity TyrosinePhosphorylation-Regulated Kinase 1A (DYRK1a). DYRK1a is an enzyme that has a critical role during brain development. The three copies of DYRK1A in DS have been hypothesized to lead to cognitive and skeletal deficits associated with DS [103]. De Toma (2019) showed that administration of EGCG partially rescues the effects of overexpression of DYRK1A in mice [104]. In a subsequent study, a potential underlying mechanism was studied, and the results indicated that re-establishment of a proper epigenetic state and rescue of the kinome deregulation may contribute to the cognitive rescue induced by green tea extracts [105]. Valenti et al., (2013) showed that EGCG strongly promotes mitochondrial biogenesis in DS human cells [106]. Another study of Valenti et al., (2016) showed that EGCG restored the impairment of mitochondria in hippocampal cells from a DS mouse model through modulation of Sirt1 and AMPK activities. However, this was not associated with free radical accumulation, suggesting that dysfunction is due to a central role in the mitochondria and not due to oxidative stress [107]. Two mouse studies focusing on cognitive performance, reported no effects of EGCG. Stringer et al. (2015) tested the effects of pure EGCG (20 mg/kg/day) in mice, either until adolescence or until adulthood on cognitive performance. This study showed that neither the short- or long-term treatment improved performance in a battery of behavioral tasks [108]. A subsequent mouse study of Stringer et al. (2016) showed that also in a higher dose ( $100 \mathrm{mg} / \mathrm{kg} / \mathrm{day})$ no improvements were found [109].

A total of three intervention studies were found, investigating the health effects of EGCG in individuals with DS. De La Torre et al (2014) combined a mouse study with a pilot randomized controlled trial, administering EGCG in doses of $9 \mathrm{mg} / \mathrm{kg} /$ day for 6 months to young adults with DS (14 to 29 years old). The study showed that the green tea flavonol epigallocatechin-gallate (EGCG), a DYRK1A inhibitor, reverses the cognitive deficits accompanying both segmental trisomy 16 (Ts65Dn) and transgenic mice overexpressing DYRK1A in a trisomic or disomic genetic background, respectively. In the pilot study in DS individuals it also significantly reduced cognitive deficits by showing positive effects on memory recognition, working memory and quality of life [95].

In a subsequent randomized controlled phase two trial of the same researchers, De la Torre et al., (2016) studied the effect of EGCG supplementation in thirty-one young adults (age 14-29) with DS [94]. Individuals were randomized to an EGCG treatment group and placebo control group. The treatment group was given two capsules per day for a period of 12 months with a mean oral dose of 9 $\mathrm{mg} / \mathrm{kg} / \mathrm{day}$. The trial was performed for six months with four moments of evaluations at baseline, at month 1 , at month 3, and 3 months after discontinuation. To assess psychomotor speed, attention, episodic memory, executive functions and visuomotor precision, a comprehensive neuropsychological battery was administered. Moreover, parents completed scales of functional ability. After three months of treatment, significantly positive effects were seen on episodic memory and working memory. In addition, significant improvements were seen for psychomotor speed and social functioning, which was measured using the kidscreen-27 quality of life index. The form filled in by parents showed that parents noticed a broad range of positive changes in the treatment group, whereas no changes were mentioned by the control group.

Xicota et al (2020) investigated the effect of EGCG on body composition and lipid profile in 77 young adults (aged 16-34 years). The subjects in this 12-month clinical trial were randomly divided into two groups, and they both received cognitive training during the trial. Besides the cognitive training, the intervention group received EGCG $(9 \mathrm{mg} / \mathrm{kg})$ a day and the other group a placebo. The effect of EGCG 
on body composition was mainly observed in males, as the males in the intervention group had a significant lower body weight and body fat as compared to the control group at the end of the trial. The changes in body composition were significantly correlated with the majority of changes in lipid profile. The results of this trial show that EGCG could have a modest beneficial effect on weight management in DS [93]. However, the sample size was too small for optimal statistical power of the tests applied. Furthermore, the specific underlying mechanism was not determined and the sexdependent effect should also be further investigated.

A recent cross-sectional study of Starbuck et al. (2021) investigated if green tea extracts with EGCG could modulate facial dysmorphologies DS [110]. These facial dysmorphologies can impair vital functions such as hearing, breathing, mastication, and health. The study was not included in Table 7, since it was an observational study The researchers analyzed the facial development of DS in two studies, where one was a Ts65Dn mouse study and the other a cross-sectional observational study in children with DS. Two doses were administered in the mouse study: low $(30 \mathrm{mg} / \mathrm{kg} / \mathrm{day})$ and high (100 mg/kg/day). The low dose was found to improve facial skeleton in Ts65Dn mouse. The high dose was associated with an increase in facial dysmorphology in Ts65Dn and euploid mice. The effect of green tea containing EGCG is therefore assumed to be dose-dependent. In the observational study children with DS whose parents administered GTE-EGCG as a green tea supplement were included. GTE-EGCG supplementation was associated with reduced facial dysmorphology in children with DS, when treatment was administered during the first three years of life. Limitations of the human observational study were the non-controlled and non-randomized condition, but the study forms a starting point for further research in a randomized controlled setting.

\subsubsection{Multivitamin- and mineral mixes (including DS-specific formulas)}

As described in the results of the online inventory in 3.1.4, there are two dietary supplements specifically aiming at children with DS: MSB NeuroPlus $\AA$ and Nutrivene-D $®$. The literature search resulted in only two clinical trials, that studied the effects of vitamin- and mineral mix supplementation in children with DS. No studies were found that used exactly these two nutritional supplements.

Meguid et al., (2015) studied the effect of nutritional supplementation on oxidative damage in Egyptian children with DS [96]. Twenty-one children with DS aged 1 month to 5 years and 20 healthy matched controls were included in the study. The children with DS received Formula $X$, a mixture of nutritional supplements comparable to the supplement mix of Nutrivene-D®, daily for six months. The formula consisted of three parts: a daily supplement, enzyme supplement and a night-time supplement. The control group received a placebo. Results were measured in blood samples before and after supplementation. At baseline the treatment group showed a higher level of oxidative stress and lower antioxidant activity compared to the control group. After supplementation, the DS group had significantly higher levels of antioxidant activity and reduced levels of oxidative stress as compared to the control group. The study concluded that Formula X might play an important role in protection against oxidative damage at early ages in individuals with DS. A limitation of this study however is that only blood markers were assessed and no physical or mental changes.

A pilot study carried out by Lakshmi and colleagues (2008) combined several vitamins and minerals in a supplement formula [97]. Forty DS children aged 5 to 16 years, received a 6-month intervention with a multivitamin and mineral mix and 40 matched healthy controls received a placebo. The authors propose that a cascade of pathological changes triggering alterations in cholinesterase-mediated functions seems to be the cause of neuronal and muscular dysfunctions, such as memory loss, disturbed cognitive skills and language impairments [97]. The aim of the study was to evaluate whether serum cholinesterases reflect the cholinergic activity at the neuronal synapses of the DS children and to study whether nutritional supplementation in these DS children had any effect on the activity of these enzymes. The study found significantly increased and more normalized values of acetylcholinesterase and butyrylcholinesterase after 6 months in the DS group compared to the control group. It is important to note that the DS group started with lower baseline values in this study. 
In addition, the websites of the MSB-Neuroplus and Nutrivene-D supplements were checked to see if scientific studies were mentioned there. The manufacturer of Nutrivene- $D \AA$ describes that in children with DS the supplement reduces infections, improves growth and improves laboratory parameters such as vitamins A, E and selenium. Moreover, behaviour, cooperation and development of the child are claimed to considerably improve. MSB NeuroPlus $\AA$ focusses specifically on the improvement of microbiome health and cognitive function in individuals with DS. The manufacturer NutriChem describes that the formula is modified in a way that maximizes the absorption of certain nutrients, also when the microbiome is off-balance. The aim of the supplement is to assist individuals with DS with their nutritional uptake.

The references that Nutrivene- $D \circledR$ are using on the website are general (mostly old) papers describing metabolic disturbances in children with DS, of which it is assumed that the DS specific formulas are improving these disturbances. Furthermore Nutrivene- $D \circledast$ is referring to a study in which children with DS noted a reduction of infections, improved growth, and improvements in laboratory parameters (vitamins A, E, selenium, etc.) and the parents and therapists involved in the study reported considerable improvements in behavior, cooperation and development of the children administered Nutrivene-D®. However, the reference is a short description of a case study of one child with DS and two experts explaining on what theoretical bases the supplement should work. No clinical trials in children with DS are mentioned on the Nutrivene-D® website. On the website of MSB NeuroPlus, no clinical studies with the supplement are mentioned either. 


\section{$4 \quad$ Discussion and conclusion}

In this chapter, the main findings per research question are summarized and discussed. Strengths and limitations of our research are described and a conclusion on the evidence for dietary supplements in children with DS is drawn. Finally, future research recommendations are described.

\subsection{Main findings and discussion}

\section{Which dietary supplements are being used in practice? And what are motivations of parents to provide their child with supplements?}

From our fieldwork, it can be concluded that the majority of parents (61\%) provide dietary supplements to their child with DS. Vitamin D (in 57\% of the 143 parents that used supplements for their child) was the most frequently provided supplement, followed by general multivitamins (43\%), vitamin C (18\%), the supplement formulas particularly aimed at people with DS (17\%), probiotics $(11 \%)$ and fish oil ( $9 \%)$. The dosages that were given to the child with DS depended on the type of supplement. Vitamin D was often given in the recommended amount, whereas most parents provided their children with more vitamin $C$ than the RDA. For general multivitamins, most parents reported to give the dosage recommended on the label or half this dosage. For multivitamins aimed at DS, usually the dosages on the label were followed.

The percentage of current and past supplement use found in our study (respectively $61 \%$, and $9 \%$ ) was higher compared to the paper of Lewanda (respectively $38 \%$, and $12 \%$ ) [43]. However, in the study of Lewanda et al, in the closed category questions, parents were asked only about certain supplements targeted at DS (e.g. curcumin, folic acid, green tea extract and formulas such as MSB NeuroPlus $\AA$ and Nutrivene- $D ®$ ). If parents used other supplements, they could add this information in an open question. In contrast, in our study we have investigated many non-DS specific supplements as well, in closed category questions. Open questions tend to lead to lower percentages, which makes the total percentages in Lewanda et al and our study difficult to compare. The study of Lewanda et al reported a relatively high use of dietary supplements aimed at DS (and this was asked through closed category questions). In their total sample of 1167 parents (including both supplement users and nonusers), curcumin was administered by 143 parents ( $12 \%$ of the total sample), folic acid by $37(3 \%)$, green tea extract by $130(11 \%)$, MSB NeuroPlus $\AA)$ by $7(1 \%)$, and Nutrivene-D $®$ by $197(17 \%)$. In our survey, the formulas aiming at DS, were used by $17 \%$ of the parents that currently administered supplements, which corresponds to a relatively low percentage of $10 \%$ of the whole sample (supplement users and non-users). Furthermore, only a very small percentage of parents indicated to provide curcumin ( $1 \%$ of the supplement users; less than $1 \%$ of the total sample), green tea extract ( $1 \%$ of the supplement users; less than $1 \%$ of the total sample) or folic acid ( $3 \%$ of the supplement users; $2 \%$ of the whole sample). The study of Long investigated the use of green tea extracts (EGCG) in the United States in children with DS [44]. They found that almost $14 \%$ of parents administer EGCG to their child, a percentage that is much higher than the $<1 \%$ we found in our whole Dutch sample. Taking both studies together, it can be concluded that these specific DS supplements are less frequently used in the Netherlands, as compared to the United States.

Regarding motivations for providing dietary supplements, parents most frequently indicated that enhancing immune system, following recommendations from a physician and improving development and overall health were important motivations. The interviews showed that parents continued providing supplements, because they observed positive effects or improvements in their child. The sources from which most parents obtain information regarding the use of nutritional supplements are a physician, the internet, social media or people in their network (e.g. fellow parents). The group who provided a DS-specific supplement had different motivations and used other information sources, than the group who provided more general dietary supplements. The most remarkable difference was that parents who provided DS-specific supplements were more often looking to improve energy levels, 
learning abilities, physical performances in their child and to counter early-onset ageing. Furthermore, their source of information was more often social media and scientific literature.

The fact that vitamin $D$ supplementation is advised by the Netherlands Nutrition Center for all children aged 0-4 years, has most likely contributed to the finding that vitamin $D$ was the most frequently administered supplement, and also to the finding that the most common motivation for supplementation was the recommendation from a physician. Parents in the survey could select multiple dietary supplements, and therefore, the effect of the vitamin $D$ advice could not be separated in the analyses. This is considered a limitation of this study. Furthermore, a considerable group of parents $(16 \%)$ indicated to provide other supplements not mentioned in our list, meaning that we might have missed a frequently used supplement.

\section{What do doctors, dieticians and other professionals advise on this topic?}

The pediatricians and dieticians that were interviewed within the context of this project (all Dutch), were rather critical on the use of dietary supplements for children with DS. They indicated a clear preference for obtaining nutrients from the basic diet. Most of these experts emphasized that supplements in high doses can cause damage to the child's health, and they found some high levels of vitamins in supplements alarming. Except for vitamin $D$ for children aged 0-4 years, there are currently no official recommendations for dietary supplements included in the DS treatment guidelines due to the lack of evidence-based research. The guidelines state that, in case of deficiencies, the regular diet must first be considered in providing sufficient amounts of vitamins and minerals. Only if the diet has been optimized, but deficiencies are still observed, dietary supplements can be prescribed. The pediatricians and dieticians indicated that their advice regarding dietary supplements is based on sufficient scientific evidence, and that this evidence for supplements in DS children is currently still lacking. In contrast, the MSB NeuroPlus $®$ supplement founder did find it reasonable to provide multivitamins to children with DS. He argued that malabsorption and deficiencies are more common in DS, and that most individuals do not obtain sufficient nutrients from their diet. Therefore, he suggested that using a multivitamin can cover this issue.

An important finding from the interviews with parents was the feeling of neglect they sometimes experience when they wish to discuss supplement use for their child with the pediatrician, as the experts mention not to prescribe them. Lewanda and colleagues (2018) describe a similar finding in their paper. In their study, some parents were reluctant to discuss supplement use with the doctor, because these parents believed the doctor was either uninformed about supplements for children with DS, or would disapprove or dismiss the question entirely [43]. It is therefore important to keep communication going between parents and the physician about the use of supplements.

\section{Which dietary supplements for people with Down syndrome are on the market? What do they claim and do they contain safe doses?}

On the Dutch market, no dietary supplements specifically aimed at people with DS can be purchased since Dutch and EU regulations do not allow it. Outside the EU, NutriChem (MSB NeuroPlus ${ }^{\circledR}$ ) and Nutrivene-D $\otimes$ sell specific dietary formulas aiming at people with DS and make several claims on their website about the effects of their product. Both supplements claim beneficial effects on health and cognition, such as neuroprotection against Alzheimer's disease and anti-inflammatory functions, a better absorption of nutrients from the diet, improving microbiome health and improvements of mood and cognitive functioning. The claims on the websites are not always backed with the right scientific evidence. Also in our literature study, we did not find clinical trials investigating beneficial effects of these specific formulas in children with DS, so at this point there seems to be no sufficient scientific basis for the claims of these supplements.

Regarding safe doses, when looking at the MSB NeuroPlus ${ }^{\circledR}$ contains higher doses of vitamin $B 1, B 2$, $B 5, B 5$ and $B 12$ than the RDA when the serving size on the label is followed. For NuTrivene-D ${ }$, the RDA is surpassed by many nutrients present in this supplement when following the recommended dosages (vitamin C, D, E, K, B1, B2, B3, B6, folic acid, B12, biotin, d-calcium, zinc and chromium).For this supplement, vitamin B6 and zinc even exceed the safe upper limits established by EFSA. This is 
worrisome as over-supplementation can lead to health problems. Supplementing too high doses of vitamin B6 can cause peripheral neuropathy and too high doses of zinc can cause a cupper deficiency (which in turn can lead to anemia, a lighter skin and osteoporosis). The Netherlands Nutrition Center recommends to not exceed $100 \%$ of the RDA when taking a dietary supplement, therefore MSB

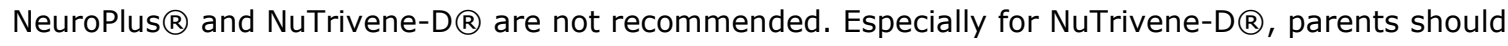
be cautious regarding the dosages and safe upper limits for children.

\section{Is there a theoretical basis in the literature why children with Down syndrome would need dietary supplements?}

Several theoretical bases for providing dietary supplements to children with DS are proposed in the scientific literature.

First of all, dietary supplements could be used to solve specific nutritional deficiencies in children with DS, although the dietary guidelines for DS state that there is a clear preference to first try and solve those deficiencies with adaptations in the regular diet [32]. There might be a higher chance on nutritional deficiencies in DS, due to typical eating behaviours, feeding problems, or perhaps lower absorption [5]. However, only a few studies were found investigating habitual dietary intake in children with DS, showing inconsistent results on whether children and adolescents with DS have a lower of a higher energy intake as compared to children without DS [57-59]. Multiple studies investigated whether specific micronutrient deficiencies are more common in children with DS by measuring micronutrient levels in blood, hair, or urine. Regarding zinc deficiencies among children with DS, three studies found lower zinc levels in blood and hair in children with DS [35, 59, 60]. It is proposed that zinc metabolism is altered in the presence of DS, and that zinc has a relationship with the metabolic alterations usually present in DS [82]. According to this theory, thyroid metabolism in children with DS could perhaps be positively affected by the intake of a zinc supplement. However, observational studies investigating zinc levels and immune status found inconsistent results, so it is unclear whether this leads to immune defects and contributions to immunological abnormalities [62]. Vitamin D deficiency was suggested to be more prevalent in children with DS than controls in two studies, however accompanying autoimmune diseases or obesity were present, or the deficiencies were assessed in a group of children with varying intellectual disabilities [34, 63]. Therefore, on the basis of these two studies it is difficult to conclude whether vitamin D deficiency is indeed more common in DS. A few studies suggest that vitamin A and iron deficiency are more common in some children with DS [33, 64-66]. Furthermore, a study of Song and colleagues showed significant decrease of vitamin B12 levels in DS subjects, whereas Hcy levels were significantly increased compared to controls. In addition, celiac disease, which is more common in children with DS, can lead to deficiencies of vitamins D, B12 and folate, and minerals calcium and iron due to malabsorption, especially if not diagnosed in time or if it remains untreated [71]. Moreover, certain types of drugs that are more commonly prescribed in children with DS, such as laxatives, PPIs and anti-epileptic drugs can cause deficiencies of the vitamins A, D, E, K, B6, folic acid, B12 and impaired calcium absorption.

To summarize, the scientific literature is not completely consistent, but there are studies indicating that deficiencies of zinc, vitamin A, D, vitamin B12, folic acid, calcium and iron are more common in people with DS. These deficiencies may be caused by typical eating behaviours, by accompanying underlying comorbidities or the use of particular medication. It should however be noted that nutritional deficiencies are not always per se due to DS, since children without DS can also develop these deficiencies. Blood tests to determine deficiencies and vitamin levels would therefore be of clinical importance and can serve as a basis for dedicated and effective supplementation.

Another theoretical basis for providing supplements, is the fact that DS is characterized by elevated oxidative stress levels [98]. Therefore, supplementing anti-oxidants might be beneficial. According to a review paper of Ani, there is reasonably strong evidence for increased oxidative stress in people with DS and there are several theoretical bases underlying it [99]. The authors also reason that these increased oxidative stress levels may play a role in the complications of DS, such as immune dysfunction, malignancy, mental development and premature ageing [99]. Another recent review of Revilla and Martinez found that several studies in murine models and DS individuals suggest that an 
increase in oxidative stress and mitochondrial dysfunction could play an important role in the development and progression of cognitive decline in DS. They found beneficial effects in preclinical studies when antioxidant therapy is administered to the Ts65Dn mouse during adult stages, but conflicting results have been reported in mice regarding its use at earlier pre- or postnatal stages (i.e., during gestation and/or infancy) [79]). According to this theory, dietary antioxidants might limit these deteriorations, which was confirmed by a mouse model study of Lockrow [100].

EGCG has many properties that are proposed to be beneficial for individuals with DS. These include the regulation of proteins involved in physiological processes such as membrane integrity, signal transduction, transcription factors, DNA methylation, phosphorylation, mitochondrial function and autophagy) [102]. Several mouse studies have shown beneficial effects of EGCG. One mouse study showed that submission of EGCG partially rescues the effects of overexpression of DYRK1A in mice [104]. Another mouse study showed that EGCG restored the impairment of mitochondria in hippocampal cells from a DS mouse model through modulation of Sirt1 and AMPK activities. Moreover, a study in DS human cells showed that EGCG strongly promotes mitochondrial biogenesis [106]. In a review paper on the possible usefulness of EGCG as a therapy in DS, Stagni and colleagues conclude that studies in various rodent models show a positive impact of EGCG on brain and behaviour, but other studies show no effect. Despite these discrepancies, possibly due to the heterogeneity of these studies, EGCG seems to exert some beneficial effects on the brain [111].

To conclude, there are several theoretical bases in literature, which could argue for dietary supplements in children with DS. First, certain vitamin and mineral deficiencies seem to be more prevalent among children with DS (although not all studies confirm this). These deficiencies could be due to the feeding and swallowing problems in early childhood and several other DS comorbidities. Secondly, people with DS seem to have higher oxidative stress levels and several mouse studies indicate positive effects of anti-oxidant supplementation. Thirdly, a few mouse studies and a study in human DS cells show beneficial effects of EGCG on the brain and behaviour. These three theoretical bases could serve as support for supplementation. Next, the scientific evidence from clinical trials in children with DS will be discussed.

\section{Is there scientific evidence for the effectiveness of supplements in relation to health or cognitive functioning?}

If yes: which supplements are effective and in which doses?

Several clinical trials investigated the effect of dietary supplements on health and cognitive outcomes. A total of 15 clinical trials in children with DS and 3 clinical trials in children and young adults with DS were included to answer this research question. The main findings are discussed below per supplement type.

Even though effects of calcium supplementation combined with exercise on bone mass density were observed in one clinical trial [81], the intervention equaled recommendations of physical exercise and calcium intake from regular nutrition. The study did however provide some evidence that adherence to these recommendations also has positive effects on bone health in children with DS. In another study it was found that hypovitaminosis D is very frequent in DS children, in particular in presence of obesity and autoimmune diseases. Positive effects of vitamin D supplementation were shown on plasma $25(\mathrm{OH}) \mathrm{D}$ levels, indicating the importance of adequate vitamin D intake to prevent low vitamin D status, and that adherence to general recommendations might be inadequate in people with DS who already have a deficiency. This seems logical, since also children without DS do often not meet the recommendations from general dietary guidelines [112]. Especially, vitamin D and folic acid intake from the diet is often insufficient, as was shown in children without DS of 2-6 years in the food consumption survey of 2016 in the Netherlands [112]. Sufficient vitamin D and calcium intake should therefore always be a point of attention in children with DS.

One small trial, including only 16 children and no control group, studied the effects of zinc supplementation on thyroid hormone metabolism in DS children [82]. Positive effects were shown on plasma zinc concentrations, but there was no difference in serum thyroid hormone concentration. 
Therefore, the authors concluded that zinc supplementation had no effect on the thyroid hormone metabolism of DS children.

Even though some clinical studies show beneficial effects of supplementation with antioxidants (mainly antioxidant vitamins) and multivitamin- and mineral mixes on reducing oxidate stress, clinical trials have shown little or no benefit to the cognitive function of children with DS. In one study improvements in psychomotor development were found, however no effect on sociability, language or coordination [92]. One of the other few studies that actually did study cognitive outcomes, a large clinical randomized trial investigating the effects of a daily combination of antioxidants (selenium, zinc, vitamins A, E and C) and folic acid, did not show any effect on language acquisition, psychomotor development nor in the levels of certain biochemical markers of oxidate stress in blood [86]. Furthermore, the findings of these clinical trials studying the effects of supplements on oxidate stress markers are limited by several facts: the designs were often not randomized, one study did not include a control group [89] and they included small sample sizes.

Interesting is the working of EGCG, since some studies have shown potential beneficial effects on cognitive outcomes, in mouse models but also in two randomized controlled trials in young adults with DS [95, 113]. Furthermore, another recent randomized controlled trial showed a moderate sexdependent effect of EGCG on body weight [93]. In a letter to the editor of Clinical Nutrition, Vacca \& Valenti (2015) plead for the use of EGCG in combination with fish oil as a safe use in a child with DS for improvements in mitochondrial dysfunctions [114]. The clinical trial of de la Torre et al., is named as evidence for safe use in humans with DS. In their letter they advise $10 \mathrm{mg} / \mathrm{kg} / \mathrm{day}$ mixed with fish oil $8 \mathrm{mg} / \mathrm{kg} /$ die containing EPA and DHA. The fish oil should enhance the bioavailability of EGCG and synergize the effects. The letter was written to support clinical trials on potential therapeutic tools. While the effect of EGCG with fish oil might be promising, the dose in the letter is based on a mouse study with a model for DS [95]. Furthermore, Vacca \& Valenti letter describe a trial in their letter, consisting of only two participants; one child with DS as a treatment group, whereas the younger brother served as a control. In a more recent publication the same group looked into the safety of EGCG and omega-3 in a pilot study with 20 DS children of 0-8 years old and they concluded it can be safely administered under medical supervision in DS children [115].

To summarize the findings on EGCG, although small positive effects on cognitive functioning were found in a few studies, the literature on beneficial effects and working of EGCG in people with DS is too limited at this point. Also, the safety and optimal doses in humans should be studied further.

So even though nutritional deficiencies are recognized in DS children, and there might be several theoretical bases in the scientific literature that support the use of supplements in children with DS, evidence on health and cognitive effects from well-designed, sufficiently powered clinical trials is insufficient at this point. We come to the same conclusion as four previous reviews looking into the evidence for beneficial effects of dietary supplements [5, 78, 80, 116]. These four authors also concluded that up till now scientific evidence insufficiently shows that nutritional supplements have beneficial effects in children with DS, except when a nutritional deficiency is present.

Very few studies on the safety of supplements in children with DS were found, while some of the doses that have been used in the supplementation studies were rather high. Also the DS-specific formulas contain high doses of certain vitamins and minerals. Gastrointestinal distress has been reported as a side-effect of dietary supplementation [5]. Furthermore, one case-control study of Blair and colleagues investigated in DS children with leukemia, whether vitamin supplements could lead to an increased risk on leukemia, but no association between supplementation and the risk of leukaemia was found in this study [117].

\section{Limitations of the clinical trials}

The scientific evidence from clinical trials investigating the effectiveness of supplements in relation to health or cognitive functioning in children with DS, is scarce and heterogeneous. This can be attributed to different factors. Some of the issues relate to a suboptimal clinical trial design (e.g. duration, dosage, no control group). Furthermore, a large amount of the studies focused on biomarkers in blood as indicator of health or cognitive functioning, and actual clinical outcomes or cognitive functioning as endpoint were often not assessed. In relation to the applied study designs, quasi-experimental designs 
were frequently applied, often non-randomized, including small sample sizes and lacking control groups. Control groups were often selected from a database (historical controls), instead of providing a control group with a placebo. Furthermore, it should be acknowledged that it is complex to conduct studies in children with DS, because of ethical considerations, but also because the number of newborns with DS is declining. This may explain why relatively few studies have been executed in this target group. Lastly, a large part of the trials included in table 8 were published in journals not so renowned, and often the impact factors of the journals were rather low.

\subsection{Strengths and limitations}

A strength of our study was the combination of both quantitative and qualitative fieldwork and literature research. Furthermore, the survey was carried out in a large sample (234 parents) and contained respondents from all over the Netherlands. In the interviews, different viewpoints on dietary supplement usage were taken into consideration; motivations and opinions of parents, doctors, dieticians and a supplement manufacturer. In this way, we obtained a complete picture on the topic. In the literature search we combined a systematic search of an information specialist, with individual searches of students and scientists of WFBR. This resulted in a comprehensive overview of the available studies in children with DS. Besides this evidence from human clinical trials, we looked into possible mechanisms for supplement usage.

We also faced some limitations during this project. The respondents of our survey were predominantly highly educated and consisted of mainly women. In this regard, the sample was not representative. Furthermore, since the survey contained mostly closed questions, certain dietary supplements or motivations might have missed in our results. The in-depth interviews were carried out in a small sample, since these interviews were exploratory. It is recommended to investigate the views of professionals on dietary supplements on a larger scale, for example by means of a survey. Since vitamin $\mathrm{D}$ was the most administered dietary supplement by parents, we assumed that the national advice for a vitamin D supplement for children 0-4 years could have played a role. However, there were only 37 children of 0 to 3 years old in the sample, and with an additional calculation we found that in this subsample $51 \%$ of parents provides supplements (which is even lower than the average of $61 \%$ for the whole sample). Therefore, it seems unlikely that the vitamin D advice intervened with our results.

The scientific evidence that we found for nutritional deficiencies in children with DS, also included studies in hair concentrations. These element concentrations observed in hair cannot always be directly translated to serum concentrations [67]. Furthermore, the conclusions that were drawn on effectiveness of dietary supplements are limited by the small body of evidence. There were relatively few studies assessing the effects of dietary supplements in children with DS, and various supplements were used. For some dietary supplements, only one or two studies were found. In addition there were differences in the applied study designs, duration of supplementation period, dosages, and age of the study population. Only few studies actually assessed clinical or cognitive outcomes, while most studies focused on improvements in blood markers. Therefore, drawing an unambiguously conclusion on positive effects of dietary supplements is difficult.

\subsection{Conclusion}

In conclusion, at present there is insufficient scientific evidence for cause-effect relationships between the use of dietary supplements and improvements in general health or cognitive functioning in children with DS. This research showed that dietary supplement use is common amongst Dutch parents of children with DS, since more than half of the parents administer supplements to their child. All types of dietary supplements were taken into account in our study and parents most often administered vitamin $D$, followed by general multivitamins and vitamin C. Only a relatively small number of parents

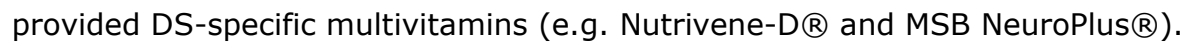


There is some scientific evidence that nutritional deficiencies are more common in children with DS, which can be due to feeding difficulties, drug use and the presence of comorbidities. It would therefore be recommended to perform blood level tests of micronutrient status in individual children with DS, to detect these deficiencies. If recommendations for a healthy food intake and healthy lifestyle do not lead to sufficient improvements of micronutrient status in an individual, dietary supplements targeted at specific deficiencies could be considered.

Some research on green tea extracts (ECGC) in relation to improving cognitive functioning in young adults with DS seems promising, and some studies showed that antioxidants reduced oxidative stress in DS mouse models and children with DS, which might positively affect the immune system and cognitive ability. However, the available evidence at this stage is far too little to advice these supplements for children with DS. Therefore, there is a clear need for more well-designed, clinical trials with validated methodologies to reach consensus about the possible benefits of supplements for children with DS.

\subsection{Recommendations for future research}

From our findings several research recommendations can be distracted. First of all, as described above there is a clear need for more well-designed, clinical trials to study the effects of several dietary supplements on health and cognitive outcomes in children with DS. These studies should be sufficiently powered, include a control group and ideally use a combination of both blood markers and actual clinical or cognitive outcomes.

Secondly, in our literature study, we found some evidence that nutritional deficiencies are more common in children with DS. However, none of the studies we found was specifically carried out in the Netherlands. Therefore, it is important to investigate whether nutritional deficiencies are indeed more common in Dutch children with DS, in order to make recommendations regarding screening on nutritional deficiencies in the DS medical guidelines or dietary guidelines.

Furthermore, even though it was out of the scope of this research project, another point of interest in children with DS is weight management, since there is a tendency towards developing obesity later in childhood. The SDS indicated to look for an answer to this specific question as well, however due to budget limitations we decided in an early stage to solely focus on dietary supplements in this project. It would be very interesting to further study the underlying causes for the development of obesity in children with DS and investigate in particular whether energy metabolism is indeed altered. In addition, it would be valuable to study what are effective strategies for developing healthy dietary habits, fitting this target group. 


\section{$5 \quad$ Advice and implications}

Based on the results of this project, several recommendations are distracted that the SDS can give to parents. The project also showed an important research recommendation. Since relatively little research has been done on dietary needs and supplements in the target group of children with DS, and their parents and caretakers do have little guidance now on how to support their child's health and cognition in this regard, more research is required to obtain a stronger base for evidence-based guidelines.

\section{Which practical advice should the SDS give to parents regarding this topic?}

- There is insufficient scientific evidence to recommend dietary supplements for improving health or cognition in children with DS.

Even though there might be several theoretical bases for providing various dietary supplements in children with DS, there is insufficient evidence from clinical trials to advice these supplements in relation to improving health or cognition. More clinical trials with validated methodology need to be performed in the future, to elucidate the potential health effects of nutritional supplements in children with DS.

- Since there is some supporting evidence that nutritional deficiencies of vitamin A, B12, $D$, folic acid, zinc, calcium and iron are more common in children with DS, care should be taken that sufficient amounts of these nutrients are obtained from the diet.

There are indications both from practice and literature that children with DS more often have nutritional deficiencies. As a first choice these nutrients should be obtained from the regular diet. A healthy diet according to the Guidelines of Healthy Nutrition from the Dutch Health Council seems extra important. Specific attention should be paid to the following foods and food groups, containing these specific micronutrients:

Sources of vitamin A: meat, dairy, fish, egg and (low-fat) margarines.

Sources of vitamin B12: milk(products), meat, fish and eggs.

Sources of vitamin D : fatty fish, eggs and (low-fat) margarines. Vitamin D is furthermore obtained from sunlight.

Sources of folic acid: green vegetables, whole-grain products, bread, meat and dairy.

- Sources of zinc: cheese, meat, grain products, nuts and shellfish.

Sources of calcium: milk (products), cheese, whole-grain bread, green leafy vegetables.

Sources of iron: green vegetables, egg, meat and meat replacers, legumes, nuts and wholegrain products.

- Follow a personalized approach: it is recommended to determine individual micronutrient status in children with DS to check for nutritional deficiencies.

Regarding nutritional deficiencies in children with DS there is no consistent picture. Therefore, a 'one-size-fits all' advise is not possible and micronutrient status should always be assessed on an individual level. In the Netherlands children with DS are under supervision of a pediatrician or an outpatient clinic specialized in DS (In Dutch "Downpoli") and pediatricians treating children with DS always follow the DS medical guideline. This guideline includes several screenings in childhood on common health issues associated with DS, such as congenital, thyroid and gastro-intestinal problems. This means that in practice it is rather unlikely that children with DS in the Netherlands will suffer from nutritional deficiencies caused by for example celiac disease, since this will be detected in an early stage.

However, blood measurements to investigate whether there are deficiencies for specific vitamins and minerals in blood, are now only performed when there is an indication to do so (for example in the case of celiac diseases). Dieticians and pediatrics treating children with DS should be aware 
about these nutritional deficiencies that are more common and should have attention for the manifestations of such deficiencies, based on the whole clinical picture of the child.

- If nutritional deficiencies are suspected, it is advised to consult a dietician who is specialized in treating children with intellectual abilities ("Diëtist VG"), a dietician who is part of an outpatient clinic specialized in Down syndrome ("Downpoli") or a pediatric dietician.

The dietician can help making improvements in the dietary pattern and makes a personal plan in collaboration with the child and the parent. If nutritional deficiencies cannot be overcome with adaptations in the regular diet, dietary supplements can be advised in consultation with the dietician or pediatrician.

- Following the national guidelines, a daily supplement of $10 \mathrm{mcg}$ vitamin $D$ for children of 0-4 years is recommended. Furthermore, sufficient vitamin $D$ and calcium intake, sunlight exposure and exercise should always be a point of attention for children with DS.

The advice for a vitamin D supplement holds for all Dutch children 0-4 years old and is also part of the dietary guidelines for children with DS. Moreover, since there are indications in literature that children with DS could be more prone to develop a vitamin D deficiency, and that they have a higher risk of reduced bone-mass accrual and thereby fractures and osteoporosis later in life, special attention should be paid to a sufficient vitamin $D$ and calcium intake from the diet. Positive effects on bone health in 7-12 year old children with DS were found when combining calcium and exercise, showing that adherence to general recommendations also has positive effects on bone health in children with DS. Therefore, all individuals with DS should be encouraged to maintain sufficient sunlight exposure (vitamin D) and healthy dietary and exercise habits as can be tolerated. From March through October, the child should be outside for 15 to 30 minutes every day between 11 a.m. and 3 p.m., with face and hands uncovered. The body builds up a supply of vitamin $D$, which is used in the winter. Children who make too little vitamin $D$ in the skin, because they get very little sunlight or have dark skin, are advised to take vitamin D supplements [118]. Furthermore it is important that individuals with DS, their parents and physicians recognize that conditions such as celiac disease or the use of anti-seizure medications adversely affect vitamin $D$ levels and increase the risk of osteoporosis, so diligence is required to ensure individuals remain vitamin $\mathrm{D}$ plus calcium sufficient. It could be that general recommendations might be inadequate in people with DS who already have a deficiency. In these cases, an extra vitamin D supplement can be advised in consultation with the dietician or pediatrician.

- If parents still wish to provide a dietary supplement, a multi-vitamin and mineral mix for children not exceeding $100 \%$ of the RDA could be provided.

In case parents still wish to provide a dietary supplement to their child with DS, it is recommended to follow the advice of the Netherlands Nutrition Center and the Netherlands Health Council, by not exceeding $100 \%$ of the RDA for the various ingredients of the supplement. A multivitamin and mineral supplement could be a good choice, especially when the parent suspects that intake from the regular diet might be insufficient. Since the RDA differs for children per age category, it is advised to purchase these supplements in the Netherlands and to look for a supplement specifically aimed at children. The pediatrician and dietician can provide advice on which type of supplement to choose, as well as on recommended dosages.

The dietary formulas aiming at people with DS (MSB NeuroPlus $\AA$ and Nutrivene-D $\AA$ ) are not allowed (and recommended) in the Netherlands, and the claims are not backed with sufficient scientific evidence from randomized controlled trials. Furthermore, vitamin B6 and zinc exceed safe upper limits in the Nutrivene-D® supplement, which can cause health risks. MSB NeuroPlus $\AA$ also contains high doses of B-vitamins, but for his supplement the safe upper limits are not exceeded in most of the age categories. 
- A healthy diet according to the Guidelines of Healthy Nutrition from the Dutch Health Council seems extra important, also in relation to more frequent nutritional deficiencies in children with $D S$.

\section{In addition a few evidence-based recommendations can be made, in order to stimulate healthy eating behaviors in children: [119, 120].}

- Make sure to have fixed eating and drinking moments (breakfast, snack, lunch, snack, diner), do not have more than four snacking moments and do not plan snacking moments too close to the main meals.

- Have dinner at the table, this helps in setting a good example, since the child will see his/her parents eat and drink.

- Make sure there is no distraction coming from television or mobile phone. Attention for food during meal-time is important.

- Set a good example, so parents can show their child that they find it important to eat healthy. The child will observe what parents eat and when, especially at a young age.

- Make sure that healthy food is available at home and easy accessible, so it is easy for the child to choose healthy food.

- Do not use food as a reward or for comfort, since this could increase the risk of overeating and obesity.

- Involve the child in meal preparation. This may not only enhance healthy eating behaviour, but also give the opportunity to develop motor- and cognitive skills of children with DS.

\section{- Keep the dialogue on dietary supplements ongoing.}

It is important that experts are understanding and engaging in conversations with parents who provide dietary supplements, even though they themselves would not recommend these specific remedies. They could still check the dosages with the parents, in order to keep the use of this supplement safe and it is also important to make the parents feel heard. In any case, it is important from both sides to keep the conversation about whether or not to provide a dietary supplement going. A special task for the SDS is to raise awareness among parents on the usage of supplements and to create a dialogue between the proponents and opponents, in which people do not feel judged on their choices. All parents strive to provide their child with the best and put their child on the first place, therefore it is important for both sides to listen to each other to prevent polarization. This can for instance be reached by organizing an interactive webinar or seminar on the topic. 


\section{References}

1. Torres, M.D. and J. Busciglio, Down syndrome, in Metabolism of human diseases. 2014, Springer. p. 53-56.

2. Agarwal Gupta, N. and M. Kabra, Diagnosis and management of Down syndrome. Indian J Pediatr, 2014. 81(6): p. 560-7.

3. Grieco, J., et al. Down syndrome: Cognitive and behavioral functioning across the lifespan. in American Journal of Medical Genetics Part C: Seminars in Medical Genetics. 2015. Wiley Online Library.

4. Bull, M.J., Health supervision for children with Down syndrome. 2011, Am Acad Pediatrics.

5. Nordstrøm, M., et al., Nutritional challenges in children and adolescents with Down syndrome. Lancet Child Adolesc Health, 2020. 4(6): p. 455-464.

6. de Graaf, G., et al., Estimation of live birth and population prevalence of Down syndrome in nine US states. American Journal of Medical Genetics Part A, 2017. 173(10): p. 2710-2719.

7. De Graaf, G., et al., Assessment of prevalence of persons with Down syndrome: A theory-based demographic model. Journal of Applied Research in Intellectual Disabilities, 2011. 24(3): p. 247262.

8. Loane, M., et al., Twenty-year trends in the prevalence of Down syndrome and other trisomies in Europe: impact of maternal age and prenatal screening. European Journal of Human Genetics, 2013. 21(1): p. 27-33.

9. Weijerman, M.E. and J.P. De Winter, Clinical practice. European journal of pediatrics, 2010. 169(12): p. 1445-1452.

10. de Graaf, G., F. Buckley, and B.G. Skotko, Estimation of the number of people with Down syndrome in Europe. European Journal of Human Genetics, 2021. 29(3): p. 402-410.

11. de Groot-van der Mooren, M., et al., Does non-invasive prenatal testing affect the livebirth prevalence of Down syndrome in the Netherlands? A population-based register study. Prenatal diagnosis, 2021.

12. Harraway, J., Non-invasive prenatal testing. Australian family physician, 2017. 46(10): p. 735.

13. Weijerman, M.E., et al., Prevalence, neonatal characteristics, and first-year mortality of Down syndrome: a national study. The Journal of pediatrics, 2008. 152(1): p. 15-19.

14. Arumugam, A., et al., Down syndrome-A narrative review with a focus on anatomical features. Clinical anatomy, 2016. 29(5): p. 568-577.

15. Lagan, N., et al., Multiorgan involvement and management in children with Down syndrome. Acta Paediatrica, 2020. 109(6): p. 1096-1111.

16. Weijerman, M.E., et al., Prevalence of congenital heart defects and persistent pulmonary hypertension of the neonate with Down syndrome. European journal of pediatrics, 2010. 169(10): p. 1195-1199.

17. Du, Y., et al., Prevalence of celiac disease in patients with Down syndrome: a meta-analysis. Oncotarget, 2018. 9(4): p. 5387.

18. Ferrari, M. and S. Stagi, Autoimmunity and genetic syndromes: A focus on down syndrome. Genes, 2021. 12(2): p. 1-10.

19. Lughetti, L., et al., Thyroid function in Down syndrome. Expert Review of Endocrinology and Metabolism, 2015. 10(5): p. 525-532.

20. Ferrari, M. and S. Stagi, Oxidative stress in Down and Williams-Beuren syndromes: an overview. Molecules, 2021. 26(11): p. 3139.

21. Borstlap, R., et al., Een update van de multidisciplinaire richtlijn voor de medische begeleiding van kinderen met Downsydroom. 2011.

22. Bergholdt, R., et al., Increased prevalence of Down's syndrome in individuals with type 1 diabetes in Denmark: a nationwide population-based study. Diabetologia, 2006. 49(6): p. 1179-1182.

23. Heller, T., et al., Caregiving, intellectual disability, and dementia: Report of the Summit Workgroup on Caregiving and Intellectual and Developmental Disabilities. Alzheimer's \& Dementia:

Translational Research \& Clinical Interventions, 2018. 4(1): p. 272-282.

24. Keator, D.B., et al., Down syndrome: Distribution of brain amyloid in mild cognitive impairment. Alzheimer's \& Dementia: Diagnosis, Assessment \& Disease Monitoring, 2020. 12(1): p. e12013.

25. Bull, M.J., Down syndrome. New England Journal of Medicine, 2020. 382(24): p. 2344-2352.

26. Arumugam, A., et al., Down syndrome-A narrative review with a focus on anatomical features. Clinical anatomy (New York, N.Y.), 2016. 29(5): p. 568-77. 
27. Skotko, B.G. and A. Tenenbaum, Down Syndrome, in Health Care for People with Intellectual and Developmental Disabilities across the Lifespan, I.L. Rubin, et al., Editors. 2016, Springer International Publishing: Cham. p. 739-750.

28. Jackson, A., et al., Clinical characteristics of dysphagia in children with Down syndrome. Dysphagia, 2016. 31(5): p. 663-671.

29. Stanley, M.A., et al., Clinical identification of feeding and swallowing disorders in 0-6 month old infants with Down syndrome. American Journal of Medical Genetics Part A, 2019. 179(2): p. 177182.

30. Díaz-Quevedo, A.A., et al., Evaluation of the craniofacial and oral characteristics of individuals with Down syndrome: a review of the literature. Journal of Stomatology, Oral and Maxillofacial Surgery, 2021.

31. G de Graaf, R.B. Downsyndroom Vademecum 2009.

32. Gehandicaptenzorg, D.V. Voedingsproblematiek bij Downsyndroom. 20182 June 2021].

33. Tenenbaum, A., et al., Anemia in children with Down syndrome. International journal of pediatrics, 2011. 2011.

34. Stagi, S., et al., Determinants of vitamin d levels in children and adolescents with down syndrome. International journal of endocrinology, 2015. 2015.

35. Saghazadeh, A., et al., Systematic review and meta-analysis shows a specific micronutrient profile in people with Down Syndrome: Lower blood calcium, selenium and zinc, higher red blood cell copper and zinc, and higher salivary calcium and sodium. PloS one, 2017. 12(4): p. e0175437.

36. Dierssen, M., et al., Down syndrome is a metabolic disease: altered insulin signaling mediates peripheral and brain dysfunctions. Frontiers in Neuroscience, 2020. 14.

37. Gameren-Oosterom, H., et al., Prevalence of Overweight in Dutch Children With Down Syndrome. Pediatrics, 2012. 130.

38. Bertapelli, F., et al., Overweight and obesity in children and adolescents with Down syndromeprevalence, determinants, consequences, and interventions: A literature review. Research in Developmental Disabilities, 2016. 57: p. 181-192.

39. Harperink-Oude Nijhuis, T.M.C. and M.H. Coolen-Klaassen, Mensen met het Downsyndroom, in Informatorium voor Voeding en Diëtetiek - Supplement 102 - augustus 2019: Dieetleer en Voedingsleer, M. Former, et al., Editors. 2019, Bohn Stafleu van Loghum: Houten. p. 1-21.

40. Nijhuis, T. and M. Coolen-Klaassen, Mensen met het Downsyndroom: Augustus 2019. 2019. p. 121.

41. Osaili, T.M., et al., Physical status and parent-child feeding behaviours in children and adolescents with Down syndrome in the United Arab Emirates. International journal of environmental research and public health, 2019. 16(13): p. 2264.

42. Grammatikopoulou, M.G., et al., Nutrient intake and anthropometry in children and adolescents with Down syndrome-a preliminary study. Developmental neurorehabilitation, 2008. 11(4): p. 260-267.

43. Lewanda, A.F., M.F. Gallegos, and M. Summar, Patterns of Dietary Supplement Use in Children with Down Syndrome. Journal of Pediatrics, 2018. 201: p. 100-105.e30.

44. Long, R., et al., Usage of and attitudes about green tea extract and Epigallocathechin-3-gallate (EGCG) as a therapy in individuals with Down syndrome. Complementary Therapies in Medicine, 2019. 45: p. 234-241.

45. Voedingscentrum, W. https://www.voedingscentrum.nl/encyclopedie/vitamine-d.aspx. 2021 [cited 202118 juli].

46. Voedingscentrum, W. https://www.voedingscentrum.nl/encyclopedie/vitamine-c.aspx. 2021 [cited 202118 juli].

47. Netherlands, H.C.o.t. Richtlijnen goede voeding 2015. 2015 [cited 202122 July ].

48. Europese Unie, VERORDENING (EG) Nr. 1924/2006 VAN HET EUROPEES PARLEMENT EN DE RAAD inzake voedings- en gezondheidsclaims voor levensmiddelen. 2006.

49. Pronk, M., Functionele voedingsmiddelen en voedingssupplementen: inventarisatie van wetgeving en richtlijnen ten aanzien van claims en veiligheid. RIVM rapport 350610001, 2005.

50. Center, N.N. Richtlijnen Schijf van Vijf. 2020 [cited 2021, 22 July].

51. Food, E.S.C.o., Tolerable Upper Intake Levels for Vitaminsand Minerals. 2006.

52. Center, N.N. Aanbevelingen voor vitamines, mineralen en spoorelementen. 2020 [cited 202122 July 2021].

53. Voedingscentrum website, Factsheet aanbevelingen voor vitamines, mineralen en spoorelementen. 2020.

54. Voedingscentrum website, https://www.voedingscentrum.nl/nl/service/vraag-enantwoord/gezonde-voeding-en-voedingsstoffen/is-te-veel-vitamine-b6-schadelijk.aspx\# : :text=Als\%20je\%20lange\%20tijd\%20te,Dit\%20noem\%20je\%20perifere\%20neuropathie. 2021 [cited 2021, 18 July]. 
55. TNO website, https://www.tno.nl/nl/aandachtsgebieden/gezond-

leven/roadmaps/youth/groeidiagrammen-in-pdf-formaat/ 2021 [cited 2021, September 15 ].

56. Voedingscentrum website.

https://www.voedingscentrum.nl/encyclopedie/koper.aspx\#: :text=Te\%20weinig\%20koper,lichaa m\%20minder\%20goed\%20koper\%20op. 2021 [cited 202118 July].

57. Magenis, M.L., et al., Dietary practices of children and adolescents with Down syndrome. Journal of Intellectual Disabilities, 2018. 22(2): p. 125-134.

58. Samarkandy, M.M., B.A. Mohamed, and A.A. Al-Hamdan, Nutritional assessment and obesity in Down syndrome children and their siblings in Saudi Arabia. Saudi Med J, 2012. 33(11): p. 1216-21.

59. Grabeklis, A.R., et al., A Search for Similar Patterns in Hair Trace Element and Mineral Content in Children with Down's Syndrome, Obesity, and Growth Delay. Biological trace element research, 2019: p. 1-11.

60. Lima, A.S., B.R. Cardoso, and S.F. Cozzolino, Nutritional status of zinc in children with Down syndrome. Biological trace element research, 2010. 133(1): p. 20-28.

61. Licastro, F., et al., Immune-endocrine status and coeliac disease in children with Down's syndrome: relationships with zinc and cognitive efficiency. Brain research bulletin, 2001. 55(2): p. 313-317.

62. Ram, G. and J. Chinen, Infections and immunodeficiency in Down syndrome. Clinical \& Experimental Immunology, 2011. 164(1): p. 9-16.

63. Cheema, M.A., K.P. Lone, and F. Razi, Quantitative ultrasound bone profile and vitamin D status in 5-11 years old children with intellectual disability. The Journal of the Pakistan Medical Association: JPMA, 2016. 66: p. 694-698.

64. Ferraz, I.S., et al., Vitamin A deficiency and association between serum retinol and IGF-1 concentrations in Brazilian children with down syndrome. Jornal de Pediatria, 2021.

65. Chávez, C., et al. Vitamin A deficiency and nutritional status in patients with Down's syndrome. in Anales de pediatria (Barcelona, Spain: 2003). 2010.

66. Mittal, S., et al., Screening for Anemia in children with Down syndrome. Journal of Developmental \& Behavioral Pediatrics, 2020. 41(2): p. 141-144.

67. Józefczuk, J., et al., Bioelements in hair of children with selected neurological disorders. Acta Biochimica Polonica, 2017. 64(2).

68. Kerkel, K., et al., Altered DNA methylation in leukocytes with trisomy 21. PLoS genetics, 2010. 6(11): p. e1001212.

69. Song, C., et al., Effect of the one-carbon unit cycle on overall DNA methylation in children with Down's syndrome. Molecular medicine reports, 2015. 12(6): p. 8209-8214.

70. Antonaros, F., et al., One-carbon pathway and cognitive skills in children with Down syndrome. Scientific Reports, 2021. 11(1): p. 1-13.

71. Oxentenko, A.S. and A. Rubio-Tapia. Celiac disease. in Mayo Clinic Proceedings. 2019. Elsevier.

72. Diemel, J., et al., NHG-standaard obstipatie. Huisarts en wetenschap, 2010. 53(9): p. 484-498.

73. Basu, T.K. and D. Donaldson, Intestinal absorption in health and disease: micronutrients. Best practice \& research Clinical gastroenterology, 2003. 17(6): p. 957-979.

74. De Bruyne, P. and S. Ito, Toxicity of long-term use of proton pump inhibitors in children. Archives of disease in childhood, 2018. 103(1): p. 78-82.

75. Harijan, P., A. Khan, and N. Hussain, Vitamin D deficiency in children with epilepsy: Do we need to detect and treat it? Journal of pediatric neurosciences, 2013. 8(1): p. 5.

76. Dinc, D. and P. Schulte, The use of anticonvulsants and the levels of folate, vitamin B12 and homocysteine. Tijdschrift voor psychiatrie, 2018. 60(1): p. 20-28.

77. Mintzer, S., C.T. Skidmore, and M.R. Sperling, B-vitamin deficiency in patients treated with antiepileptic drugs. Epilepsy \& behavior, 2012. 24(3): p. 341-344.

78. Roizen, N.J., Complementary and alternative therapies for Down syndrome. Ment Retard Dev Disabil Res Rev, 2005. 11(2): p. 149-55.

79. Rueda Revilla, N. and C. Martínez-Cué, Antioxidants in down syndrome: From preclinical studies to clinical trials. Antioxidants, 2020. 9(8): p. 692.

80. Salman, M., Systematic review of the effect of therapeutic dietary supplements and drugs on cognitive function in subjects with Down syndrome. Eur J Paediatr Neurol, 2002. 6(4): p. 213-9.

81. Reza, S.M., et al., Effects of calcium and training on the development of bone density in children with Down syndrome. Res Dev Disabil, 2013. 34(12): p. 4304-9.

82. do Nascimento Marreiro, D., et al., Effect of zinc supplementation on thyroid hormone metabolism of adolescents with Down syndrome. Biological trace element research, 2009. 129(1): p. 20-27.

83. Nachvak, S.M., et al., a-Tocopherol supplementation reduces biomarkers of oxidative stress in children with Down syndrome: a randomized controlled trial. European journal of clinical nutrition, 2014. 68(10): p. 1119-1123.

84. Parisotto, E.B., et al., Antioxidant intervention attenuates oxidative stress in children and teenagers with Down syndrome. Res Dev Disabil, 2014. 35(6): p. 1228-36. 
85. Parisotto, E.B., et al., Persistence of the benefit of an antioxidant therapy in children and teenagers with Down syndrome. Res Dev Disabil, 2015. 45-46: p. 14-20.

86. Ellis, J.M., et al., Supplementation with antioxidants and folinic acid for children with Down's syndrome: randomised controlled trial. Bmj, 2008. 336(7644): p. 594-7.

87. Gualandri, W., et al., Redox balance in patients with Down's syndrome before and after dietary supplementation with alpha-lipoic acid and L-cysteine. International journal of clinical pharmacology research, 2003. 23(1): p. 23-30.

88. Larsen, E.L., et al., The effect of long-term treatment with coenzyme Q10 on nucleic acid modifications by oxidation in children with Down syndrome. Neurobiology of aging, 2018. 67: p. 159-161.

89. Tiano, L., et al., Prolonged coenzyme Q10 treatment in Down syndrome patients, effect on DNA oxidation. Neurobiology of Aging, 2012. 33(3): p. 626.e1-626.e8.

90. Tiano, L., et al., Effect of Coenzyme Q10 in mitigating oxidative DNA damage in Down syndrome patients, a double blind randomized controlled trial. Neurobiology of Aging, 2011. 32(11): p. 21032105.

91. Miles, M.V., et al., Coenzyme Q10 (ubiquinol-10) supplementation improves oxidative imbalance in children with trisomy 21. Pediatr Neurol, 2007. 37(6): p. 398-403.

92. Blehaut, $\mathrm{H}_{\text {., }}$ et al., Effect of leucovorin (folinic acid) on the developmental quotient of children with Down's syndrome (trisomy 21) and influence of thyroid status. PLoS One, 2010. 5(1): p. e8394.

93. Xicota, L., et al., Effect of epigallocatechin gallate on the body composition and lipid profile of down syndrome individuals: Implications for clinical management. Clinical nutrition, 2020. 39(4): p. 1292-1300.

94. de la Torre, R., et al., Safety and efficacy of cognitive training plus epigallocatechin-3-gallate in young adults with Down's syndrome (TESDAD): a double-blind, randomised, placebo-controlled, phase 2 trial. The Lancet Neurology, 2016. 15(8): p. 801-810.

95. De la Torre, R., et al., Epigallocatechin-3-gallate, a DYRK1A inhibitor, rescues cognitive deficits in Down syndrome mouse models and in humans. Mol Nutr Food Res, 2014. 58(2): p. 278-88.

96. Meguid, N.A., et al., Antioxidant activity in Egyptian children with Down syndrome before and after nutritional supplementation. Journal of Chemical and Pharmaceutical Research, 2015. 7(2): p. 324331.

97. Lakshmi, K.T., et al., Serum cholinesterases in Down syndrome children before and after nutritional supplementation. Singapore Med J, 2008. 49(7): p. 561-4.

98. Garlet, T.R., et al., Systemic oxidative stress in children and teenagers with Down syndrome. Life Sci, 2013. 93(16): p. 558-63.

99. Ani, C., S. Grantham-McGregor, and D. Muller, Nutritional supplementation in Down syndrome: theoretical considerations and current status. Developmental Medicine \& Child Neurology, 2000. 42(3): p. 207-213.

100. Lockrow, J., et al., Cholinergic degeneration and memory loss delayed by vitamin E in a Down syndrome mouse model. Exp Neurol, 2009. 216(2): p. 278-89.

101. Ellis, J., et al., Inequalities in provision of the Disability Living Allowance for Down syndrome. Archives of Disease in Childhood, 2008. 93(1): p. 14-16.

102. Pervin, M., et al., Beneficial effects of green tea catechins on neurodegenerative diseases. Molecules, 2018. 23(6): p. 1297.

103. Duchon, A. and Y. Herault, DYRK1A, a Dosage-Sensitive Gene Involved in Neurodevelopmental Disorders, Is a Target for Drug Development in Down Syndrome. Front Behav Neurosci, 2016. 10: p. 104.

104. De Toma, I., et al., DYRK1A Overexpression Alters Cognition and Neural-Related Proteomic Pathways in the Hippocampus That Are Rescued by Green Tea Extract and/or Environmental Enrichment. Front Mol Neurosci, 2019. 12: p. 272.

105. De Toma, I., et al., Re-establishment of the epigenetic state and rescue of kinome deregulation in Ts65Dn mice upon treatment with green tea extract and environmental enrichment. Scientific reports, 2020. 10(1): p. 1-18.

106. Valenti, D., et al., Epigallocatechin-3-gallate prevents oxidative phosphorylation deficit and promotes mitochondrial biogenesis in human cells from subjects with Down's syndrome. Biochim Biophys Acta, 2013. 1832(4): p. 542-52.

107. Valenti, D., et al., The polyphenols resveratrol and epigallocatechin-3-gallate restore the severe impairment of mitochondria in hippocampal progenitor cells from a Down syndrome mouse model. Biochimica et Biophysica Acta (BBA)-Molecular Basis of Disease, 2016. 1862(6): p. 1093-1104.

108. Stringer, M., et al., Low dose EGCG treatment beginning in adolescence does not improve cognitive impairment in a Down syndrome mouse model. Pharmacology Biochemistry and Behavior, 2015. 138: p. 70-79. 
109. Stringer, M., et al., Deficits in a Radial-Arm Maze Spatial Pattern Separation Task and Cell Proliferation in a Mouse Model for Down Syndrome. 2016.

110. Starbuck, J.M., et al., Green tea extracts containing epigallocatechin-3-gallate modulate facial development in Down syndrome. Scientific Reports, 2021. 11(1): p. 1-13.

111. Stagni, F., et al., Epigallocatechin gallate: A useful therapy for cognitive disability in Down syndrome? Neurogenesis, 2017. 4(1): p. e1270383.

112. Ocke, M., Dutch National Food Consumption Survey Young Children 2005/2006. RIVM, 2008.

113. de la Torre, R., et al., Safety and efficacy of cognitive training plus epigallocatechin-3-gallate in young adults with Down's syndrome (TESDAD): a double-blind, randomised, placebo-controlled, phase 2 trial. Lancet Neurol, 2016. 15(8): p. 801-810.

114. Vacca, R.A. and D. Valenti, Green tea EGCG plus fish oil omega-3 dietary supplements rescue mitochondrial dysfunctions and are safe in a Down's syndrome child. Clinical nutrition, 2015. 34(4): p. 783-784.

115. Scala, I., et al., Epigallocatechin-3-Gallate Plus Omega-3 Restores the Mitochondrial Complex I and FOF1-ATP Synthase Activities in PBMCs of Young Children with Down Syndrome: A Pilot Study of Safety and Efficacy. Antioxidants, 2021. 10(3): p. 469.

116. Martínez Cué, C. and M. Dierssen, Plasticity as a therapeutic target for improving cognition and behavior in Down syndrome. Prog Brain Res, 2020. 251: p. 269-302.

117. Blair, C.K., et al., Vitamin supplement use among children with Down's syndrome and risk of leukaemia: a Children's Oncology Group (COG) study. Paediatr Perinat Epidemiol, 2008. 22(3): p. 288-95.

118. Voedingscentrum. Vitamine D advies. 2021 [cited 202116 September].

119. Birch, L., J.S. Savage, and A. Ventura, Influences on the development of children's eating behaviours: from infancy to adolescence. Canadian journal of dietetic practice and research: a publication of Dietitians of Canada= Revue canadienne de la pratique et de la recherche en dietetique: une publication des Dietetistes du Canada, 2007. 68(1): p. s1.

120. Scaglioni, S., et al., Factors influencing children's eating behaviours. Nutrients, 2018. 10(6): p. 706. 


\section{Annex 1 Ethical clearance}


DATE

29-04-2021

SUBJECT

Ethical approval of research project

POSTAL ADDRESS

6706 kn Hollandseweg 1

Wageningen

The Netherlands

VISITORS' ADDRESS

Building 201

INTERNET

www.wur.nl/university

The following project proposal has been reviewed by the Social Sciences Ethics Committee (SEC):

Title:

Dietary supplements in children with Down Syndrome

Project team: Sandra van der Haar

Funding: Wageningen Science Shop

Period: January - September 2021

Location: Wageningen University \& Research

The Committee has concluded that the proposal deals with ethical issues in a satisfactory way and that it complies with the Netherlands Code of Conduct for Research Integrity.

With kind regards,

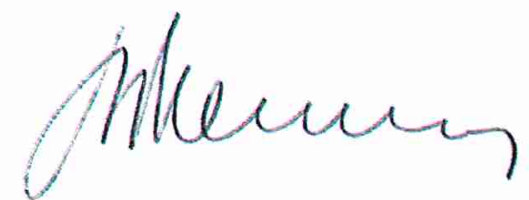

Professor Dr Marcel Verweij

Chair Social Sciences Ethics Committee
COC NUMBER

HANDLED BY

TELEPHONE

$+31(0) 317484334$

EMAIL

esther.roquas@wur.n
Prof. Dr Marcel Verweij 


\section{Annex 2 Survey parents}




\section{WAGENINGEN UNIVERSITY \& RESEARCH}

Beste ouder/verzorger,

Bedankt dat u wilt meewerken aan ons onderzoek! Wij zijn studenten van zowel de master opleiding Nutrition and Health als de master opleiding Communication, Health and Life Sciences. Wij voeren dit onderzoek uit in opdracht van Wageningen University and Research (WUR), in samenwerking met Stichting Downsyndroom (SDS).

De volgende enquête heeft betrekking op het gebruik van voedingssupplementen voor kinderen met het syndroom van Down. Het doel van deze enquête is om een beeld te schetsen van de huidige situatie omtrent het gebruik van voedingssupplementen. Om een zo compleet mogelijk beeld te krijgen, zijn we zowel geïnteresseerd in ouders die hun kinderen

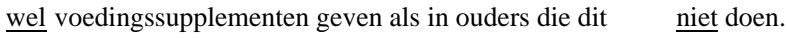

De enquête bestaat uit gesloten vragen, waarbij er soms ook een optie is om zelf een ander antwoord in te vullen dat niet tussen de antwoordmogelijkheden vermeld staat. Formuleer uw antwoord alstublieft zo duidelijk en helder mogelijk.

Voordat u start met het invullen van de enquête willen wij u graag op het volgende attenderen:

$\mathrm{U}$ dient een ouder of verzorger te zijn van een kind met het syndroom van Down.

Deelname aan dit onderzoek is geheel vrijwillig en volledig anoniem.

U kunt op elk moment uw deelname aan het onderzoek stopzetten.

U dient ouder dan 18 jaar te zijn.

De onderzoeksgegevens worden op een vertrouwelijke manier bewerkt. Na afloop van het onderzoek worden deze geanonimiseerde gegevens - volgens wettelijke bewaartermijn - 10 jaar bewaard.

Indien u meer wilt weten over dit onderzoek, verwijzen wij u door naar de website van het onderzoek: https://www.wur.nl/nl/show/Voedingssupplementen-bij-kinderen-met-Downsyndroom.htm

Bij voorbaat dank voor uw deelname.

Q1: Voordat u start met de enquête, vragen wij u hieronder toestemming geven voor deelname aan dit onderzoek.

Ik ga akkoord met deelname aan dit onderzoek.

Q2: 1. Wat is uw geslacht?

$\bigcirc$ Man

Vrouw

$\bigcirc$ Anders/wil ik niet zeggen

Q3: 2. Wat is de relatie met uw kind?

Ik ben vader (biologisch/stief/pleeg)

Ik ben moeder (biologisch/stief/pleeg)

$\bigcirc$ Andere primaire verzorger

$\bigcirc$ Anders, namelijk: 
Q4: 3. Wat is het geslacht van uw kind?

$\bigcirc$ Jongen

$\bigcirc$ Meisje

Anders/wil ik niet zeggen

Q5: 4. Hoe oud is uw kind?

Q6: 5. Wat is de lengte van uw kind?

Q7: 6. Wat is het gewicht van uw kind?

Q8: 7. Hoe zou u de algemene fysieke gezondheid en algemene eetgewoontes van uw kind omschrijven?

\begin{tabular}{lcccccc} 
& 1. slecht & 2. matig & 3. neutraal & 4. goed & 5. uitmuntend & \\
\hline 7.1. Algemene fysieke gezondheid & $\bigcirc$ & $\bigcirc$ & $\bigcirc$ & $\bigcirc$ & $\bigcirc$ \\
\hline 7.2. Algemene eetgewoontes & $\bigcirc$ & $\bigcirc$ & $\bigcirc$ & $\bigcirc$ & $\bigcirc$
\end{tabular}

De volgende vragen hebben betrekking op het al dan niet geven van voedingssupplementen aan uw kind met het syndroom van Down. Onder voedingssupplementen worden alle pillen, poeders, druppels, capsules of drankjes die extra vitamines, mineralen en/of bioactieve stoffen bevatten verstaan.

Q11: 8. Heeft uw kind voor zover u weet, zonder supplementen, tekorten aan bepaalde voedingsstoffen?

$\bigcirc \mathrm{Ja}$, dat heb ik in het afgelopen jaar laten testen.

Ja, dat heb ik meer dan een jaar geleden laten testen.

Waarschijnlijk, dat baseer ik op het dieet van mijn kind.

Nee, mijn kind heeft geen tekorten. Dat heb ik in het afgelopen jaar laten testen.

Nee, mijn kind heeft geen tekorten. Dat heb ik meer dan een jaar geleden laten testen.

Dit weet ik niet zeker, ik heb dit nooit laten testen.

$\bigcirc$ Anders, namelijk: 
Q12: 8.1. Aan welke voedingsstof(fen) heeft uw kind tekorten? Er zijn meerdere antwoorden mogelijk.

\begin{tabular}{l}
$\square$ Vitamine A \\
$\square$ Bèta-caroteen \\
$\square$ Vitamine B1 (Thiamine) \\
$\square$ Vitamine B2 (Riboflavine) \\
$\square$ Vitamine B5 (Pantotheenzuur) \\
$\square$ Vitamine B6 (Pyridoxine) \\
$\square$ Vitamine B11 (Foliumzuur) \\
$\square$ Vitamine B12 (Cobalamine) \\
$\square$ Vitamine C \\
$\square$ Vitamine D \\
$\square$ Vitamine E \\
$\square$ Vitamine K \\
\hline Calcium \\
$\square$ Chromium \\
$\square$ IJzer \\
Jodium \\
$\square$ Kalium \\
Magnesium \\
Selenium \\
Zink \\
Anders, namelijk:
\end{tabular}

Q13: 8.1. Aan welke voedingsstof(fen) heeft uw kind waarschijnlijk tekorten? Er zijn meerdere antwoorden mogelijk.

$\square$ Vitamine A

$\square$ Bèta-caroteen

$\square$ Vitamine B1 (Thiamine)

$\square$ Vitamine B2 (Riboflavine)

$\square$ Vitamine B5 (Pantotheenzuur)

$\square$ Vitamine B6 (Pyridoxine)

$\square$ Vitamine B11 (Foliumzuur)

$\square$ Vitamine B12 (Cobalamine)

$\square$ Vitamine $\mathrm{C}$

$\square$ Vitamine D

$\square$ Vitamine $\mathrm{E}$

$\square$ Vitamine $\mathrm{K}$

$\square$ Calcium

$\square$ Chromium

$\square$ IJzer

$\square$ Jodium

$\square$ Kalium

$\square$ Magnesium

$\square$ Selenium

$\square$ Zink

$\square$ Anders, namelijk: 
Q14: 9. Geeft u uw kind op dit moment wel eens voedingssupplementen?

Ja

Op dit moment niet, ik heb dit in het verleden ook niet gedaan.

Op dit moment niet, maar dit heb ik in het verleden wel gedaan.

Q15: 9.1. Welke voedingsstoffen, vitamines, mineralen, bioactieve stoffen etc. geeft $u$ uw kind in de vorm van een supplement? Deze informatie kunt $u$ vinden op de verpakking van het voedingssupplement. Er zijn meerdere antwoorden mogelijk. Indien u een multivitamine geeft, hoeft $u$ bij deze vraag niet alle losse voedingsstoffen in de multivitamine aan te geven.

$\square$ Multivitamine(n)

$\square$ Multivitamine(n) specifiek voor Downsyndroom (bijvoorbeeld MSB Neuro plus / MSB-methyl)

$\square$ Vitamine A

$\square$ Bèta-carotenen

$\square$ Vitamine B1 (Thiamine)

$\square$ Vitamine B2 (Riboflavine)

$\square$ Vitamine B5 (Pantotheenzuur)

$\square$ Vitamine B6 (Pyridoxine)

$\square$ Vitamine B11 (Foliumzuur)

$\square$ Vitamine B12 (Cobalamine)

$\square$ Vitamine $\mathrm{C}$

$\square$ Vitamine D

$\square$ Vitamine E

$\square$ Vitamine $\mathrm{K}$

$\square$ Calcium

$\square$ Chromium

$\square$ IJzer

$\square$ Jodium

$\square$ Kalium

$\square$ Magnesium

$\square$ Selenium

$\square$ Zink

$\square$ Probiotica

$\square$ Prebiotica

$\square$ Visolie (EPA/DHA)

$\square$ Melatonine

$\square$ Trehalose

$\square$ Cysteïne

$\square$ Kurkuma

$\square$ Resveratrol

$\square$ EGCG (Epigallocatechin gallaat/groene thee extract)

$\square$ Anders

Q16: 9.2. Hoe heet/heten de multivitamine(n) die u geeft aan uw kind? Denk hierbij aan de naam van het supplement en het merk.

Q17: 9.2. Hoe heet/heten de multivitamine(n) die u geeft aan uw kind? Denk hierbij aan de naam van het supplement en het merk. 
Q18: 10.1. Deze vraag gaat over het voedingssupplement 'multivitamine'. Welke dosering van dit supplement geeft u aan uw kind? Denk hierbij aan het aantal pillen/schepjes poeder, en indien vermeld op het potje/doosje, de grootte of het gewicht van de pil/schepjes poeder.

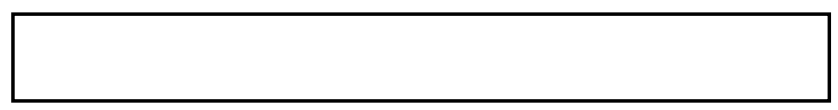

Q19: 10.2. Deze vraag gaat over het voedingssupplement 'multivitamine specifiek voor Downsyndroom'. Welke dosering van dit supplement geeft u aan uw kind? Denk hierbij aan het aantal pillen/schepjes poeder, en indien vermeld op het potje/doosje, de grootte of het gewicht van de pil/schepjes poeder.

-

Q20: 10.3. Deze vraag gaat over het voedingssupplement 'vitamine A'. Welke dosering van dit supplement geeft u aan uw kind? Vermeld hierbij ook de eenheid die op het potje/doosje vermeld staat (bijvoorbeeld microgram $/ \mu \mathrm{g}$ of $\mathrm{mcg}$, milligram $/ \mathrm{mg}$, gram $/ \mathrm{g}$, colony-forming units/cfu.

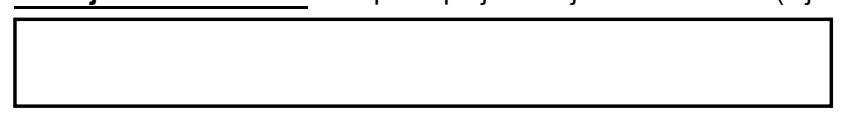

Q21: 10.4. Deze vraag gaat over het voedingssupplement 'bèta-carotenen'. Welke dosering van dit supplement geeft u aan uw kind? Vermeld hierbij ook de eenheid die op het potje/doosje vermeld staat (bijvoorbeeld microgram/ $\mathrm{hg}$ of mcg, milligram/mg, gram/g, colony-forming units/cfu.

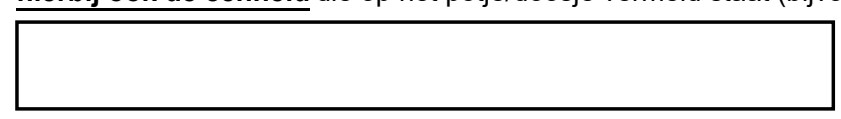

Q22: 10.5. Deze vraag gaat over het voedingssupplement 'vitamine B1 (Thiamine)'. Welke dosering van dit supplement geeft u aan uw kind? Vermeld hierbij ook de eenheid die op het potje/doosje vermeld staat (bijvoorbeeld microgram $/ \mathrm{\mu g}$ of $\mathrm{mcg}, \mathrm{milligram} / \mathrm{mg}, \mathrm{gram} / \mathrm{g}$, colony-forming units/cfu.

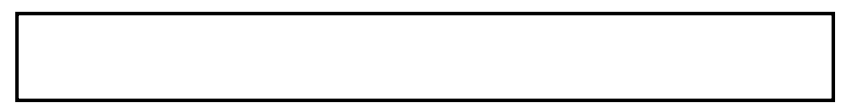

Q23: 10.6. Deze vraag gaat over het voedingssupplement 'vitamine B2 (Riboflavine)'. Welke dosering van dit supplement geeft u aan uw kind? Vermeld hierbij ook de eenheid die op het potje/doosje vermeld staat (bijvoorbeeld microgram/ng of $\mathrm{mcg}, \mathrm{milligram} / \mathrm{mg}, \mathrm{gram} / \mathrm{g}$, colony-forming units/cfu.

Q24: 10.7. Deze vraag gaat over het voedingssupplement 'vitamine B5 (Pantotheenzuur)'. Welke dosering van dit supplement geeft u aan uw kind? Vermeld hierbij ook de eenheid die op het potje/doosje vermeld staat (bijvoorbeeld microgram $/ \mathrm{\mu g}$ of $\mathrm{mcg}, \mathrm{milligram} / \mathrm{mg}, \mathrm{gram} / \mathrm{g}$, colony-forming units/cfu.

Q25: 10.8. Deze vraag gaat over het voedingssupplement 'vitamine B6 (Pyridoxine)'. Welke dosering van dit supplement geeft u aan uw kind? Vermeld hierbij ook de eenheid die op het potje/doosje vermeld staat (bijvoorbeeld microgram/ug of $\mathrm{mcg}, \mathrm{milligram} / \mathrm{mg}$, gram $/ \mathrm{g}$, colony-forming units/cfu.

Q26: 10.9. Deze vraag gaat over het voedingssupplement 'vitamine B11 (Foliumzuur)'. Welke dosering van dit supplement geeft u aan uw kind? Vermeld hierbij ook de eenheid die op het potje/doosje vermeld staat (bijvoorbeeld microgram $/ \mu \mathrm{g}$ of $\mathrm{mcg}, \mathrm{milligram} / \mathrm{mg}, \mathrm{gram} / \mathrm{g}$, colony-forming units/cfu. 
Q27: 10.10. Deze vraag gaat over het voedingssupplement 'vitamine B12 (Cobalamine)'. Welke dosering van dit supplement geeft u aan uw kind? Vermeld hierbij ook de eenheid die op het potje/doosje vermeld staat (bijvoorbeeld microgram/ $\mathrm{mg}$ of $\mathrm{mcg}, \mathrm{milligram} / \mathrm{mg}, \mathrm{gram} / \mathrm{g}$, colony-forming units/cfu.

Q28: 10.11. Deze vraag gaat over het voedingssupplement 'vitamine C'. Welke dosering van dit supplement geeft u aan uw kind? Vermeld hierbij ook de eenheid die op het potje/doosje vermeld staat (bijvoorbeeld microgram/ $\mathrm{mg}$ of $\mathrm{mcg}$, milligram $/ \mathrm{mg}$, gram/g, colony-forming units/cfu.

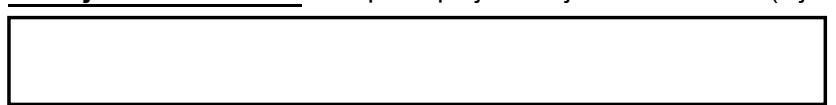

Q29: 10.12. Deze vraag gaat over het voedingssupplement 'vitamine $D$ '. Welke dosering van dit supplement geeft u aan uw kind? Vermeld hierbij ook de eenheid die op het potje/doosje vermeld staat (bijvoorbeeld microgram/ $\mathrm{\mu g}$ of $\mathrm{mcg}$, milligram $/ \mathrm{mg}$, gram/g, colony-forming units/cfu.

-

Q30: 10.13. Deze vraag gaat over het voedingssupplement 'vitamine E'. Welke dosering van dit supplement geeft u aan uw kind? Vermeld hierbij ook de eenheid die op het potje/doosje vermeld staat (bijvoorbeeld microgram/ $\mathrm{\mu g}$ of $\mathrm{mcg}$, milligram $/ \mathrm{mg}$, gram/g, colony-forming units/cfu.



Q31: 10.14. Deze vraag gaat over het voedingssupplement 'vitamine K'. Welke dosering van dit supplement geeft u aan uw kind? Vermeld hierbij ook de eenheid die op het potje/doosje vermeld staat (bijvoorbeeld microgram/ $\mu \mathrm{g}$ of $\mathrm{mcg}$, milligram $/ \mathrm{mg}$, gram/g, colony-forming units/cfu.

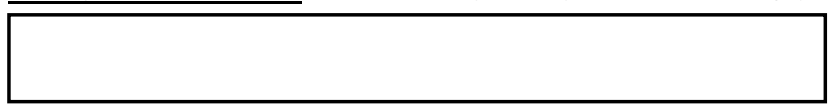

Q32: 10.15. Deze vraag gaat over het voedingssupplement 'calcium'. Welke dosering van dit supplement geeft u aan uw kind? Vermeld hierbij ook de eenheid die op het potje/doosje vermeld staat (bijvoorbeeld microgram/. $\mathrm{g}$ of $\mathrm{mcg}$, milligram/mg, gram/g, colony-forming units/cfu.

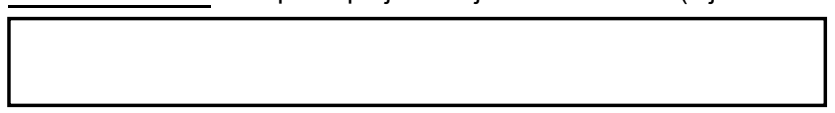

Q33: 10.16. Deze vraag gaat over het voedingssupplement 'chromium'. Welke dosering van dit supplement geeft u aan uw kind? Vermeld hierbij ook de eenheid die op het potje/doosje vermeld staat (bijvoorbeeld microgram $/ \mu \mathrm{g}$ of $\mathrm{mcg}$, milligram $/ \mathrm{mg}$, gram $/ \mathrm{g}$, colony-forming units/cfu.

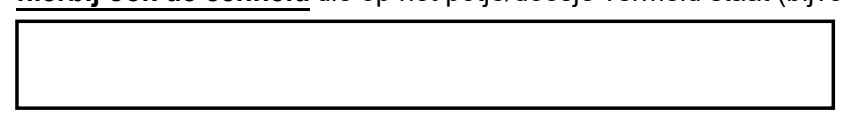

Q34: 10.17. Deze vraag gaat over het voedingssupplement 'ijzer'. Welke dosering van dit supplement geeft u aan uw kind? Vermeld hierbij ook de eenheid die op het potje/doosje vermeld staat (bijvoorbeeld microgram/ug of $\mathrm{mcg}$, milligram/mg, gram/g, colony-forming units/cfu.

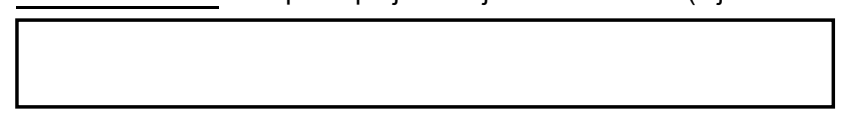

Q35: 10.18. Deze vraag gaat over het voedingssupplement 'jodium'. Welke dosering van dit supplement geeft u aan uw kind? Vermeld hierbij ook de eenheid die op het potje/doosje vermeld staat (bijvoorbeeld microgram/ng of mcg, milligram/mg, gram/g, colony-forming units/cfu. 
Q36: 10.19. Deze vraag gaat over het voedingssupplement 'kalium'. Welke dosering van dit supplement geeft u aan uw kind? Vermeld hierbij ook de eenheid die op het potje/doosje vermeld staat (bijvoorbeeld microgram/ $\mathrm{mg}$ of $\mathrm{mcg}$, milligram/mg, gram/g, colony-forming units/cfu.

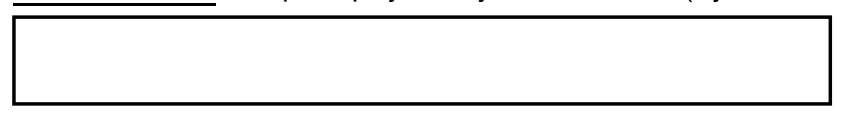

Q37: 10.20. Deze vraag gaat over het voedingssupplement 'magnesium'. Welke dosering van dit supplement geeft u aan uw kind? Vermeld hierbij ook de eenheid die op het potje/doosje vermeld staat (bijvoorbeeld microgram/ $\mathrm{hg}$ of $\mathrm{mcg}$, milligram/mg, gram/g, colony-forming units/cfu.

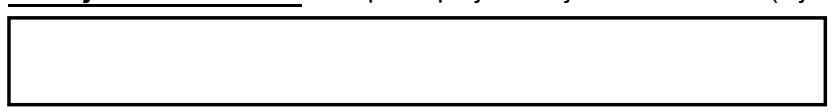

Q38: 10.21. Deze vraag gaat over het voedingssupplement 'selenium'. Welke dosering van dit supplement geeft u aan uw kind? Vermeld hierbij ook de eenheid die op het potje/doosje vermeld staat (bijvoorbeeld microgram/ $\mathrm{\mu g}$ of $\mathrm{mcg}$, milligram/mg, gram/g, colony-forming units/cfu.

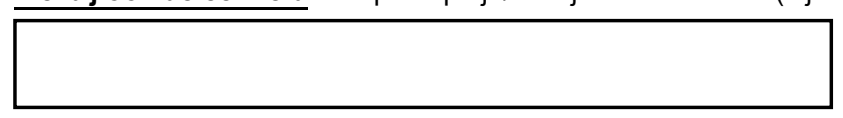

Q39: 10.22. Deze vraag gaat over het voedingssupplement 'zink'. Welke dosering van dit supplement geeft u aan uw kind? Vermeld hierbij ook de eenheid die op het potje/doosje vermeld staat (bijvoorbeeld microgram/ $\mathrm{gg}$ of $\mathrm{mcg}$, milligram/mg, gram/g, colony-forming units/cfu.

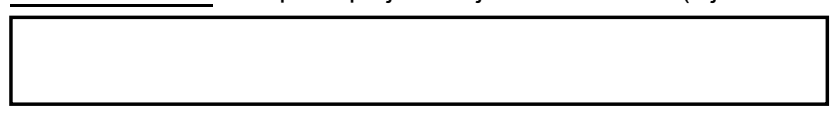

Q40: 10.23. Deze vraag gaat over het voedingssupplement 'probiotica'. Welke dosering van dit supplement geeft u aan uw kind? Vermeld hierbij ook de eenheid die op het potje/doosje vermeld staat (bijvoorbeeld microgram/ $\mathrm{\mu g}$ of $\mathrm{mcg}$, milligram $/ \mathrm{mg}$, gram/g, colony-forming units/cfu.

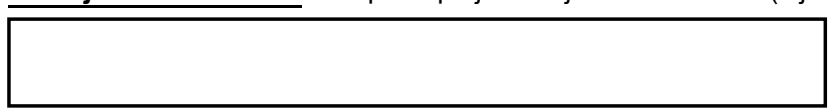

Q41: 10.24. Deze vraag gaat over het voedingssupplement 'prebiotica'. Welke dosering van dit supplement geeft u aan uw kind? Vermeld hierbij ook de eenheid die op het potje/doosje vermeld staat (bijvoorbeeld microgram/ $\mathrm{\mu g}$ of $\mathrm{mcg}$, milligram $/ \mathrm{mg}$, gram $/ \mathrm{g}$, colony-forming units/cfu.

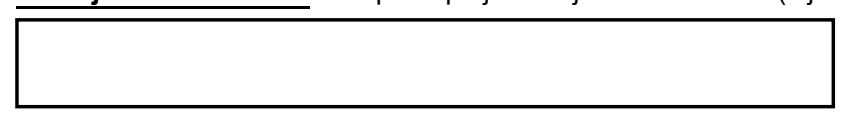

Q42: 10.25. Deze vraag gaat over het voedingssupplement 'visolie (EPA/DHA)'. Welke dosering van dit supplement geeft u aan uw kind? Vermeld hierbij ook de eenheid die op het potje/doosje vermeld staat (bijvoorbeeld microgram/ $\mathrm{\mu g}$ of $\mathrm{mcg}$, $\mathrm{milligram} / \mathrm{mg}$, gram/g, colony-forming units/cfu.

Q43: 10.26. Deze vraag gaat over het voedingssupplement 'melatonine'. Welke dosering van dit supplement geeft u aan uw kind? Vermeld hierbij ook de eenheid die op het potje/doosje vermeld staat (bijvoorbeeld microgram/ $\mathrm{gg}$ of $\mathrm{mcg}$, milligram $/ \mathrm{mg}$, gram $/ \mathrm{g}$, colony-forming units/cfu.

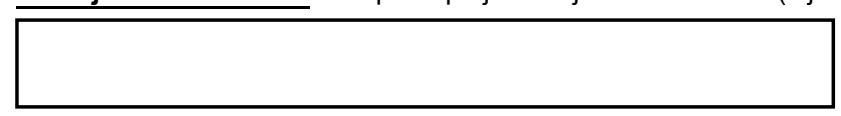

Q44: 10.27. Deze vraag gaat over het voedingssupplement 'trehalose'. Welke dosering van dit supplement geeft u aan uw kind? Vermeld hierbij ook de eenheid die op het potje/doosje vermeld staat (bijvoorbeeld microgram/ $\mathrm{\mu g}$ of $\mathrm{mcg}$, milligram $/ \mathrm{mg}, \mathrm{gram} / \mathrm{g}$, colony-forming units/cfu.

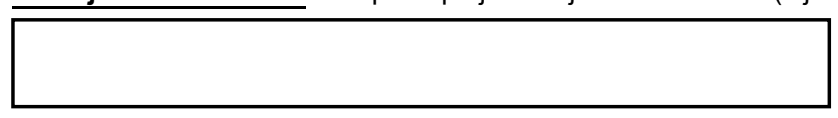


Q45: 10.28. Deze vraag gaat over het voedingssupplement 'cysteïne'. Welke dosering van dit supplement geeft u aan uw kind? Vermeld hierbij ook de eenheid die op het potje/doosje vermeld staat (bijvoorbeeld microgram/ $\mathrm{\mu g}$ of $\mathrm{mcg}$, milligram $/ \mathrm{mg}$, gram/g, colony-forming units/cfu.

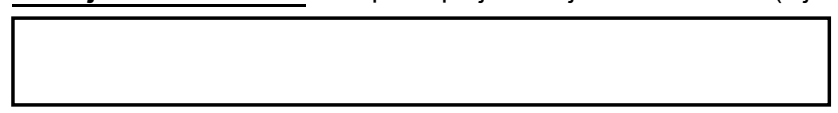

Q46: 10.29. Deze vraag gaat over het voedingssupplement 'kurkuma'. Welke dosering van dit supplement geeft u aan uw kind? Vermeld hierbij ook de eenheid die op het potje/doosje vermeld staat (bijvoorbeeld microgram/ $\mu \mathrm{g}$ of $\mathrm{mcg}$, milligram $/ \mathrm{mg}, \mathrm{gram} / \mathrm{g}$, colony-forming units/cfu.

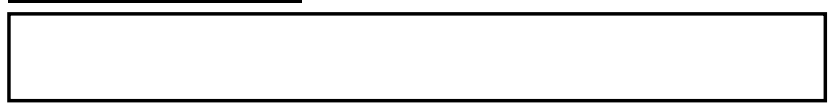

Q47: 10.30. Deze vraag gaat over het voedingssupplement 'resveratrol'. Welke dosering van dit supplement geeft u aan uw kind? Vermeld hierbij ook de eenheid die op het potje/doosje vermeld staat (bijvoorbeeld microgram/ $\mu \mathrm{g}$ of $\mathrm{mcg}$, milligram $/ \mathrm{mg}$, gram/g, colony-forming units/cfu.

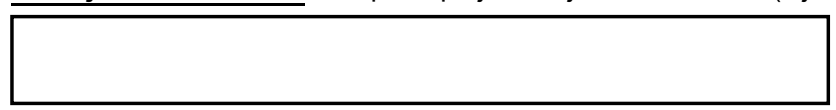

Q48: 10.31. Deze vraag gaat over het voedingssupplement 'EGCG (Epigallocatechin gallaat/groene thee extract)'. Welke dosering van dit supplement geeft $\mathrm{u}$ aan uw kind? Vermeld hierbij ook de eenheid die op het potje/doosje vermeld staat (bijvoorbeeld $\mathrm{microgram} / \mathrm{\mu g}$ of $\mathrm{mcg}$, milligram/mg, gram/g, colony-forming units/cfu.

Q49: 10.32. U heeft bij de vraag over de soort voedingssupplementen die u aan uw kind geeft 'anders' aangegeven. Wat voor supplement(en) geeft $u$ aan uw kind en in welke dosering? Vermeld hierbij ook de eenheid die op het potje/doosje vermeld staat (bijvoorbeeld microgram/ $\mu$ g of $\mathrm{mcg}$, milligram/mg, gram/g, colony-forming units/cfu.

Q50: 11. Van welke merken koopt u voedingssupplementen? Er zijn meerdere antwoorden mogelijk.
$\square$ Huismerk(en)
$\square$ Holland \& Barrett
$\square$ A. Vogel
$\square$ Lucovitaal
$\square$ Davitamon
NutriChem (DSM)
$\square$ Vitaminstore
$\square$ Vitals
$\square$ Melvita
$\square$ Nutramin
$\square$ Royal Green
$\square$ Metagenic
Anders, namelijk: 
Q51: 12. Waar koopt u voedingssupplementen? Er zijn meerdere antwoorden mogelijk.

$\square$ Supermarkt

$\square$ Drogisterij

$\square$ Apotheek

$\square$ Online (binnen de Europese Unie)

$\square$ Online (buiten de Europese Unie)

Anders, namelijk:

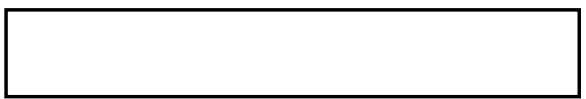

Q52: 13. Vanaf welke leeftijd bent $\mathrm{u}$ begonnen met het geven van voedingssupplementen aan uw kind?

Q53: 14. Wat is de reden dat $\mathrm{u}$ uw kind deze voedingssupplement(en) geeft?

$\square$ Om de weerstand van mijn kind te verhogen

$\square$ Om mijn kind meer energie te geven gedurende de dag

$\square$ Omdat mijn kind via voeding deze stoffen niet binnenkrijgt

$\square$ Omdat mijn kind (waarschijnlijk) een tekort aan deze voedingsstof(fen) heeft

$\square$ Op aanraden van een arts

$\square$ Op aanraden van een diëtist

$\square$ Op aanraden van een andere expert

$\square$ Om de leerprestaties van mijn kind te verbeteren

$\square$ Om de fysieke prestaties van mijn kind te verbeteren

$\square$ Om vroegtijdige veroudering tegen te gaan

$\square$ Op aanraden van andere ouders/verzorgers van kinderen met Downsyndroom

$\square$ Ik heb hier geen specifieke reden voor, maar denk dat het in ieder geval geen kwaad kan

$\square$ Anders, namelijk:

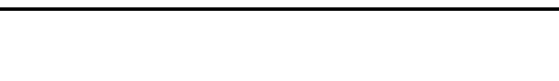

Q54: 14.1. Om wat voor/welke expert gaat dit? (bijvoorbeeld fysiotherapeut)

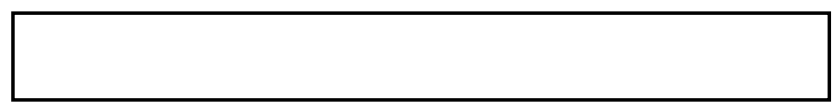

Q55: 15. Hoe vaak geeft u deze supplementen aan uw kind?

$\bigcirc$ (bijna) dagelijks

Een aantal keer per week

1 keer per week

1 keer per 2 weken

1 keer per maand

Een paar keer per jaar

Soms een periode wel en soms een periode niet.

Anders, namelijk: 
Q56: 16. Is de huidige huisarts/kinderarts van uw kind op de hoogte van het supplementen gebruik?

Ja

$\bigcirc$ Nee

Q57: 10. Wat is de reden dat u uw kind geen voedingssupplementen geeft?

$\square$ Ik vind het niet nodig om mijn kind voedingssupplementen te geven.

$\square$ Ik vertrouw voedingssupplementen niet.

$\square$ Mijn kind wilt geen voedingssupplementen slikken.

$\square$ Ik vind voedingssupplementen te duur.

$\square$ Ik heb nog nooit nagedacht over het geven van voedingssupplementen aan mijn kind.

Anders, namelijk:

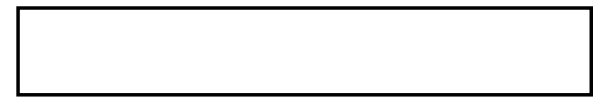

Q58: 10. Wat is de reden dat $\mathrm{u}$ bent gestopt met het geven van voedingssupplementen aan uw kind?

$\square$ Mijn kind had geen voedingstekorten meer na het gebruik van voedingssupplementen.

$\square$ Ik zag geen effect bij mijn kind na het gebruik van voedingssupplementen.

$\square$ Ik zag negatieve effecten bij mijn kind na het gebruik van voedingssupplementen.

$\square$ Ik heb hier geen specifieke reden voor.

$\square$ Anders, namelijk:

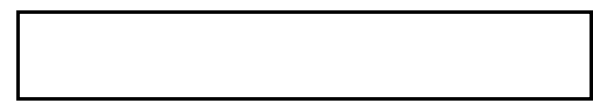

Q59: 10.1. Wat voor negatieve effecten ervaarde u bij uw kind?

$\square$ Negatieve gedragsverandering(en)

$\square$ Fysieke klachten

$\square$ Verminderde leerprestaties

$\square$ Anders, namelijk:

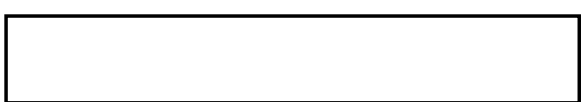

Q60: 17. Wat is uw ervaring met betrekking tot het geven van voedingssupplementen aan uw kind?

\begin{tabular}{lcccccc} 
& 1. Slecht & 2. Matig & 3. Neutraal & 4. Goed & 5. Uitmuntend \\
\hline Ervaring & $\bigcirc$ & $\bigcirc$ & $\bigcirc$ & $\bigcirc$ & $\bigcirc$
\end{tabular}

Q62: 11. Wat is uw ervaring in het verleden met betrekking tot het geven van voedingssupplementen aan uw kind?

\begin{tabular}{lcccccc} 
& 1. Slecht & 2. Matig & 3. Neutraal & 4. Goed & 5. Uitmuntend \\
\hline Ervaring & $\bigcirc$ & $\bigcirc$ & $\bigcirc$ & $\bigcirc$ & $\bigcirc$
\end{tabular}


Q64: 18. Waar heeft $\mathrm{u}$ de informatie over het wel of niet geven van voedingssupplementen aan uw kind verkregen? Er zijn meerdere antwoorden mogelijk.

$\square$ Via een arts

$\square$ Via een diëtist

$\square$ Via een andere gezondheidsspecialist

$\square$ Via een organisatie gespecialiseerd in Downsyndroom

$\square$ Via informatie op internet

$\square$ Via sociale media (fora, facebook-groepen, etc.)

$\square$ Via mensen in uw omgeving

$\square$ Via een advertentie of andere reclame-uiting

$\square$ Via wetenschappelijke literatuur

$\square$ Ik heb geen informatie over het geven van voedingssupplementen

$\square$ Anders, namelijk:

Q65: 18.1. Om wat voor/welke gezondheidsspecialist gaat dit?

Q66: 18.1. Om welke organisatie gaat dit?

Als laatste willen we u nog wat vragen stellen omtrent u en uw eventuele partner en uw relatie tot de Stichting Downsyndroom. Dit doen we om te kijken hoe representatief onze steekproef is.

Q67: 19. Wat is uw hoogst genoten opleiding?

Lagere school (en LAVO, VGLO)

VMBO (en voormalige MAVO, LBO vormen) + eerste drie jaar Havo/VWO

Havo/VWO (afgerond), Atheneum, Gymnasium, NMS, HBS, Lyceum

MBO (MTS, UTS, MEAO)

HBO en Universiteit

$\mathrm{PhD} /$ promotie

Niet van toepassing

$\bigcirc$ Dat zeg ik liever niet

Q68: 20. Wat is de hoogst genoten opleiding van de eventuele andere ouder/verzorger van uw kind?

Lagere school (en LAVO, VGLO)

VMBO (en voormalige MAVO, LBO vormen) + eerste drie jaar Havo/VWO

Havo/VWO (afgerond), Atheneum, Gymnasium, NMS, HBS, Lyceum

MBO (MTS, UTS, MEAO)

$\bigcirc \mathrm{HBO}$ en Universiteit

$\mathrm{PhD} /$ promotie

Niet van toepassing

$\bigcirc$ Dat zeg ik liever niet 
Q69: 21. Bent u donateur van Stichting Downsyndroom?

$\bigcirc \mathrm{Ja}$

Nee

Q70: 22. Wilt u kans maken op één van de bol.com cadeaubonnen die wij verloten? Vul dan hieronder uw mailadres in. Dit is e-mailadres wordt apart van uw overige antwoorden opgeslagen en na verloting van de cadeaubonnen weer verwijderd.

niet verplicht. Uw

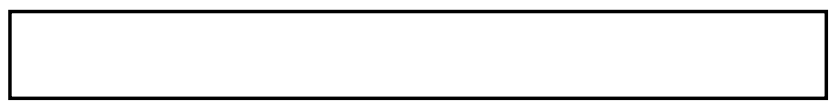

Q71: 23. Heeft u nog opmerkingen naar aanleiding van deze enquête?

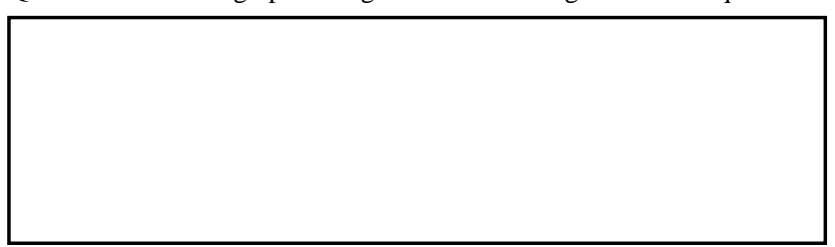

Wij danken u voor uw deelname aan deze enquête. Ons onderzoek zal bijdragen aan een toepasbaar advies omtrent het geven van voedingssupplementen aan kinderen met Downsyndroom. Dit advies zal in het najaar uitgebracht en met u gedeeld worden via Stichting Downsyndroom.

Heeft u vragen over het gebruik van voedingssupplementen, neem dan contact op met uw arts of diëtist.

Klik nu op 'verzenden'. 


\section{Annex 3 Interview questions}




\section{Interview questions for the parents}

1. Kunt u kort iets meer vertellen over uw kind met het syndroom van Down? Geslacht, lengte, gewicht, leeftijd, eventuele beperkingen die uw kind ondervindt door het syndroom van Down.

2. In hoeverre krijgt $u$ begeleiding bij de opvoeding van uw kind? Sociale kring, loopt u bij een arts/diëtist o.i.d.

3. Kunt $u$ iets meer vertellen over het voedingspatroon van uw kind? Schijf van 5, vlees/vis, groenten/fruit, vochtinname (zoete dranken/frisdrank), gezond gewicht.

4. Ervaart uw kind voedingsgerelateerde problemen?

Problemen met slikken, kauwen, afkeer tegen voedsel, intolerantie/allergieën.

5. Heeft u uw kind ooit laten testen op voedingstekorten?

Zo ja, wanneer heeft u uw kind laten testen en welke voedingstekorten kwamen naar voren? Zo nee, verwacht $u$ op basis van het voedingspatroon of andere kenmerken van uw kind dat uw kind voedingstekorten heeft?

6. Weet u wat voedingssupplementen zijn?

Definitie van het voedingscentrum: voedingssupplementen zijn producten in de vorm van pillen, poeders, druppels, capsules of drankjes en zijn bedoeld als aanvulling op de dagelijkse voeding. Ze bevatten vitamines, mineralen of bioactieve stoffen, zowel apart, zoals in een vitamine $C$ pil, of als combinatie, zoals in een multivitaminepil.

7. Leest $u$ of hoort $u$ veel over voedingssupplementen in uw omgeving/andere ouders van kinderen met het syndroom van Down?

8. Geeft u voedingssupplementen aan uw kind?

Zo ja, welke en in welke mate (dosis, frequentie etc.)

9. Waarom geeft u uw kind wel/geen voedingssupplementen?

Waar haalt u deze informatie vandaan (wetenschappelijke artikelen, internet, sociale media, arts/diëtist, ervaring van mensen uit de omgeving)?

Zo nee, maar in het verleden wel: heeft $u$ in het verleden negatieve effecten ondervonden van het gebruik van voedingssupplementen of heeft $u$ andere redenen voor het stoppen (geld, geen tekorten meer etc.)?

10. (WEL voedingssupplementen) Wat is uw ervaring met het geven van voedingssupplementen? Merkt u positieve/negatieve effecten?

Lichamelijke effecten, stemming, gedrag.

11. (WEL voedingssupplementen) Van welk(e) merk(en) en waar koopt u voedingssupplementen?

Waar let u op (mark, branding, prijs etc.)? Waarom koopt u specifiek dit merk? Waarom koopt u de supplementen hier?

a. Hoeveel geld geeft u maandelijks uit aan supplementen?

In hoeverre speelt geld een rol?

12. Weet $u$ of er specifieke voedingssupplementen voor kinderen met het syndroom van Down op de markt zijn?

Motivatie waarom hier wel of geen gebruik van gemaakt wordt.

Dit was de laatste vraag van het interview. Is er nog iets wat u wilt toevoegen, vragen of opmerken?

Bedankt voor uw deelname aan dit interview! 


\section{Interview questions for the experts}

1. Wat is uw beroep en hoe lang voert u dit beroep al uit?

2. Op wat voor manier bent u gespecialiseerd in/heeft u te maken met het syndroom van Down in uw werk en hoe lang al?

3. Hoeveel kinderen met het syndroom van Down behandelt/ziet u ongeveer?

4. Zijn er voedingsdeficiënties of voedingsgerelateerde problemen die $u$ in de praktijk vaak ziet bij kinderen met het syndroom van Down?

5. Zijn er specifieke gevolgen van deze voedingsdeficiënties zichtbaar bij kinderen met het syndroom van Down?

6. (DIËTISTEN) Wat adviseert u aan (verzorgers van) kinderen met het syndroom van Down met betrekking tot hun dieet?

7. Ziet u veel ouders die hun kinderen met het syndroom van Down voedingssupplementen geven?

8. Heeft u een idee of er veel supplementen specifiek voor het syndroom van Down op de markt zijn?

Zo ja, welke supplementen zijn dit?

9. Hoe schat u over het algemeen de kennis in van ouders met kinderen met het syndroom van Down met betrekking tot voedingssupplementen?

10. Is er iets opgenomen in de behandelingsrichtlijnen over het gebruik van voedingssupplementen bij het syndroom van Down?

11. Is er, naar uw weten, wetenschappelijk bewijs voor de effectiviteit van voedingssupplementen op de mentale en fysieke gezondheid van kinderen met het syndroom van Down?

12. Wat is uw mening over het gebruik van voedingssupplementen voor kinderen met het syndroom van Down? Denkt u dat voedingssupplementen positieve (of zelfs negatieve) effecten kunnen hebben op het leven van kinderen met het syndroom van Down?

13. Geeft $u$ wel eens een advies aan verzorgers van kinderen met het syndroom van Down met betrekking tot voedingssupplementen of verstrekt u slechts informatie hierover?

14. Zijn er specifieke voedingssupplementen die u (altijd) adviseert aan (verzorgers van) kinderen met het syndroom van Down?

15. Waarop baseert u uw advies aan ouders met betrekking tot voedingssupplementen? Wetenschappelijke inzichten, ervaringen van ouders, combinatie hiervan etc.

16. Denkt u dat voedingssupplementen nodig zijn voor kinderen met het syndroom van Down om voedingsdeficiënties te voorkomen of om de algemene gezondheid te verbeteren?

Dit was de laatste vraag van het interview. Is er nog iets wat u wilt toevoegen, vragen of opmerken? Bedankt voor uw deelname aan dit interview! 


\section{Interview questions for the supplement manufacturer (Nutrichem)}

1. Can you tell us something about yourself, your education and your career?

2. Can you tell us something about NutriChem?

a. What type of service do you provide to your customers/clients?

b. How big a role does Down syndrome play in your organisation?

3. What supplements aimed at people with Down syndrome does NutriChem produce?

4. What is it that MSB does in people with Down syndrome? Which nutrients play what role? What effects can people expect after taking the supplement? Some parents reported a high or low energy level upon consumption of MSB, do you have an explanation for this?

5. Can you tell us more about the scientific basis behind MSB?

6. How did you develop the composition of MSB?

a. Do the nutrients in the supplement meet recommended daily intakes?

b. We saw that some of the ingredients exceed the (Dutch) daily recommended intake. We saw that mainly multiple B vitamins (B1, B2, B5, B6, B12) are higher than the RDA. Why is this?

7. On what do you base the dosages of MSB?

a. Do you think that parents generally stick to the dosages on the label? Or do they give more or less? How do you feel about this?

8. We read on your site that the composition of MSB has been altered a few times already. Which changes were made and based on which insights?

9. Do you assess the efficacy/effectiveness of MSB?

If yes, how?

10. Of course, NutriChem, is specialised in personalised health solutions. However, we have found that many Dutch parents order the 'standard' MSB formula. What is the difference in composition and effect between the standard MSB supplement and a personalised supplement?

11. Are you aware of Dutch parents who order personalised supplements from NutriChem? a. When do you advise people to order personalised supplements?

b. On what do you base the composition of the supplements?

c. How often do you reassess the composition?

d. Is it possible to perform the analyses used in the Netherlands (or somewhere else) or do people have to go to Canada for this?

12. Does your company collaborate with first-line health experts, like doctors or dieticians?

13. What is your opinion about the use of nutritional supplements among people with Down Syndrome?

Is the current use sufficient? Does your opinion on supplements differ for people with Down syndrome and people without Down syndrome?

This was your final question. Do you have any questions, remarks or anything else you would like to tell us? Thank you very much for taking the time to participate in this interview 


\section{Annex 4 Literature search log}

\section{Pubmed exact search}

\begin{tabular}{|c|c|c|c|}
\hline Q1 & $\begin{array}{l}\text { Children with } \\
\text { Down } \\
\text { syndrome }\end{array}$ & $\begin{array}{l}\text { ("down syndrome"[Title/Abstract] OR "down's } \\
\text { syndrome"[Title/Abstract] OR "downs syndrome"[Title/Abstract] } \\
\text { OR "trisomy 21"[Title/Abstract] OR "down syndrome"[MeSH } \\
\text { Terms] OR ("down syndrome"[Text Word] OR "down's } \\
\text { syndrome"[Text Word] OR "downs syndrome"[Text Word] OR } \\
\text { "trisomy } 21 \text { "[Text Word])) AND (("infan*"[Text Word] OR } \\
\text { "child*"[Text Word] OR "adolescen*"[Text Word] OR } \\
\text { "pediatric*"[Text Word] OR "paediatric*"[Text Word] OR } \\
\text { "pube*"[Text Word] OR "juvenil*"[Text Word] OR "school*"[Text } \\
\text { Word] OR "newborn*"[Title/Abstract] OR "new } \\
\text { born*"[Title/Abstract] OR "neo nat*"[Title/Abstract] OR } \\
\text { "neonat*"[Title/Abstract] OR "premature*"[Title/Abstract] OR } \\
\text { "postmature*"[Title/Abstract] OR "pre mature*"[Title/Abstract] } \\
\text { OR "post mature*"[Title/Abstract] OR "preterm*"[Title/Abstract] } \\
\text { OR "pre term*"[Title/Abstract] OR "baby"[Title/Abstract] OR } \\
\text { "babies"[Title/Abstract] OR "toddler*"[Title/Abstract] OR } \\
\text { "youngster*"[Title/Abstract] OR "preschool*"[Title/Abstract] OR } \\
\text { "kindergart*"[Title/Abstract] OR "kid"[Title/Abstract] OR } \\
\text { "kids"[Title/Abstract] OR "playgroup*"[Title/Abstract] OR "play } \\
\text { group*"[Title/Abstract] OR "playschool*"[Title/Abstract] OR } \\
\text { "prepube*"[Title/Abstract] OR "preadolescen*"[Title/Abstract] } \\
\text { OR "junior high*"[Title/Abstract] OR } \\
\text { "highschool*"[Title/Abstract] OR "senior high"[Title/Abstract] OR } \\
\text { "young people*"[Title/Abstract] OR "minors"[Title/Abstract]) } \\
\text { NOT ("animals"[MeSH Terms] NOT ("humans"[MeSH Terms] } \\
\text { AND "animals"[MeSH Terms]))) }\end{array}$ & 17,652 \\
\hline Q2 & Supplement & $\begin{array}{l}\text { "dietary supplement*"[Title/Abstract] OR "food } \\
\text { supplement*"[Title/Abstract] OR "vitamin } \\
\text { supplement*"[Title/Abstract] OR "nutritional } \\
\text { supplement*"[Title/Abstract] OR "antioxidant*"[Title/Abstract] } \\
\text { OR "antioxidant therapy"[Title/Abstract] OR "dietary } \\
\text { supplements"[MeSH Terms] OR "dietary supplements"[MeSH } \\
\text { Terms] OR "vitamins"[Pharmacological Action] OR } \\
\text { "vitamins"[MeSH Terms] OR "antioxidants"[MeSH Terms] OR } \\
\text { "antioxidants/therapy"[MeSH Terms] OR "dietary } \\
\text { supplement*"[Text Word] OR "food supplement*"[Text Word] } \\
\text { OR "vitamin supplement*"[Text Word] OR "nutritional } \\
\text { supplement*"[Text Word] OR "antioxidant*"[Text Word] OR } \\
\text { "antioxidant therapy"[Text Word] }\end{array}$ & 634,712 \\
\hline Q3 & & Q1 AND Q2 & 301 \\
\hline \multirow[t]{2}{*}{ Q4 } & Outcome & $\begin{array}{l}\text { Q3 AND ("Health"[Title/Abstract] AND "effect*"[Title/Abstract]) } \\
\text { OR ("Health"[Title/Abstract] AND "benefit*"[Title/Abstract]) OR } \\
\text { ("health effect*"[Text Word] OR "health benefit*"[Text Word]) } \\
\mathbf{1} \text { relevant article was added }\end{array}$ & 6 \\
\hline & & $\begin{array}{l}\text { Q3 AND "wellbeing"[Title/Abstract] OR "well- } \\
\text { being"[Title/Abstract] OR "wellbeing"[Text Word] OR "well- } \\
\text { being"[Text Word] OR "well-being"[Text Word] }\end{array}$ & 0 \\
\hline
\end{tabular}




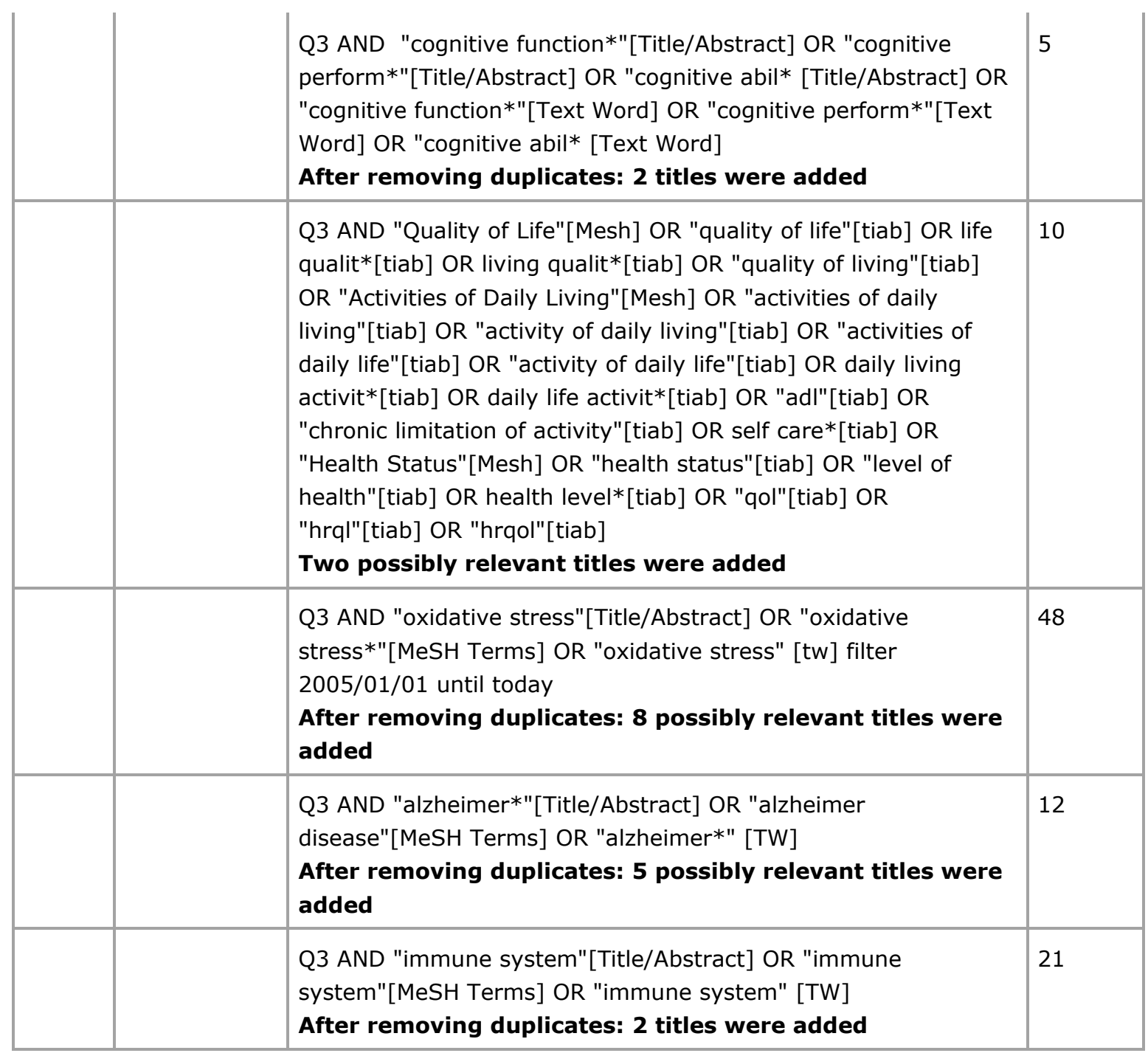

\section{Pubmed broad search}

\begin{tabular}{|l|l|l|l|}
\hline Q1 & $\begin{array}{l}\text { Children with } \\
\text { Down } \\
\text { syndrome }\end{array}$ & $\begin{array}{l}\text { ("down syndrome"[Title/Abstract] OR "down's } \\
\text { syndrome"[Title/Abstract] OR "downs syndrome"[Title/Abstract] } \\
\text { OR "trisomy 21"[Title/Abstract] OR "down syndrome"[MeSH } \\
\text { Terms] OR ("down syndrome"[Text Word] OR "down's } \\
\text { syndrome"[Text Word] OR "downs syndrome"[Text Word] OR } \\
\text { "trisomy 21"[Text Word])) }\end{array}$ & 32,368 \\
\hline Q2 & Outcome & $\begin{array}{l}\text { "Bone mineral density"[All Fields] OR ("memories"[All Fields] OR } \\
\text { "memory"[MeSH Terms] OR "memory"[All Fields] OR "memory } \\
\text { s"[All Fields]) OR "communication skill*"[All Fields] OR "learning } \\
\text { abil*"[All Fields] OR "language develop*"[All Fields] OR "Working } \\
\text { memory"[All Fields] OR ("nerve degeneration"[MeSH Terms] OR } \\
\text { ("nerve"[All Fields] AND "degeneration"[All Fields]) OR "nerve } \\
\text { degeneration"[All Fields] OR "neurodegeneration"[All Fields] OR } \\
\text { "neurodegenerating"[All Fields] OR "neurodegenerations"[All } \\
\text { Fields]) }\end{array}$ & 480,961 \\
\hline Q3 & Supplement & $\begin{array}{l}\text { "vitamin A"[Title/Abstract] OR "retinol"[Title/Abstract] OR } \\
\text { "vitamin A"[MeSH Terms] }\end{array}$ & 60,396 \\
\hline & \begin{tabular}{l} 
Q1 AND Q2 AND Q3 \\
\hline
\end{tabular} & 3 \\
\hline
\end{tabular}




\begin{tabular}{|c|c|c|c|}
\hline Q4 & Supplement & $\begin{array}{l}\text { "Vitamin D"[MeSH Terms] OR "receptors, calcitriol"[MeSH Terms] } \\
\text { OR "Calcitriol"[MeSH Terms] OR "cathelicidin II } 371829 \\
\text { human"[Supplementary Concept] OR "Vitamin D"[Title/Abstract] } \\
\text { OR "vitamin d3"[All Fields] OR "calciol"[Title/Abstract] OR } \\
\text { "cholecalciferol*"[Title/Abstract] OR } \\
\text { "colecalciferol*"[Title/Abstract] OR "calcifediol*"[Title/Abstract] } \\
\text { OR "hydroxycholecalciferol*"[Title/Abstract] OR } \\
\text { "hydroxyvitamins d"[Title/Abstract] OR "calcidiol"[Title/Abstract] } \\
\text { OR "hydroxyvitamin d3"[Title/Abstract] OR } \\
\text { "calderol*"[Title/Abstract] OR "dedrogyl"[Title/Abstract] OR } \\
\text { "hidroferol"[Title/Abstract] OR } \\
\text { "dihydroxycholecalciferol*"[Title/Abstract] OR "dihydroxyvitamins } \\
\text { d"[Title/Abstract] OR "dihydroxyvitamin d3"[Title/Abstract] OR } \\
\text { "Calcitriol"[Title/Abstract] OR "cathelicidin"[Title/Abstract] OR } \\
\text { "calciferol*"[Title/Abstract] OR "vitamin d2"[Title/Abstract] OR } \\
\text { "ergocalciferol*"[Title/Abstract] OR "hydroxyvitamin } \\
\text { d2"[Title/Abstract] OR "hydroxyvitamin d"[Title/Abstract] OR } \\
\text { "hydroxycalciferol*"[Title/Abstract] OR } \\
\text { "hydroxyergocalciferol"[Title/Abstract] OR } \\
\text { "dihydrotachysterin"[Title/Abstract] OR } \\
\text { "tachystin"[Title/Abstract] OR "calcamine*"[Title/Abstract] OR } \\
\text { "dihydrotachysterol*"[Title/Abstract] }\end{array}$ & 94,353 \\
\hline & & Q1 AND Q2 AND Q4 & 4 \\
\hline \multirow[t]{2}{*}{ Q5 } & & $\begin{array}{l}\text { "calcium"[Title/Abstract] OR "calcium, dietary"[MeSH Terms] OR } \\
\text { "dietary calcium"[Title/Abstract] }\end{array}$ & 389,959 \\
\hline & & $\begin{array}{l}\text { Q1 AND Q2 AND Q5 } \\
\text { After removing duplicates: } 20 \text { titles were added }\end{array}$ & 22 \\
\hline \multirow[t]{2}{*}{ Q6 } & & $\begin{array}{l}\text { "vitamin e"[Title/Abstract] OR "tocopherol*"[Title/Abstract] OR } \\
\text { "tocotrienol*"[Title/Abstract] OR "alpha } \\
\text { tocopherol*"[Title/Abstract] OR "alpha } \\
\text { tocopherol*"[Title/Abstract] OR "vitamin e"[MeSH Terms] OR } \\
\text { "tocopherols"[MeSH Terms] OR "tocotrienols"[MeSH Terms] }\end{array}$ & 50,621 \\
\hline & & $\begin{array}{l}\text { Q1 AND Q2 AND Q6 } \\
\text { After removing duplicates: } 1 \text { titles was added }\end{array}$ & 2 \\
\hline \multirow[t]{2}{*}{ Q7 } & & $\begin{array}{l}\text { "vitamin m"[Title/Abstract] OR "vitamin b9"[Title/Abstract] OR } \\
\text { "folic acid"[Title/Abstract] OR "folvite"[Title/Abstract] OR } \\
\text { "folacin"[Title/Abstract] OR "folate"[Title/Abstract] OR "folic } \\
\text { acid"[MeSH Terms] OR "folinic acid"[Title/Abstract] }\end{array}$ & 59,800 \\
\hline & & $\begin{array}{l}\text { Q1 AND Q2 AND Q7 } \\
\text { After removing duplicates: } 1 \text { titles was added }\end{array}$ & 2 \\
\hline \multirow[t]{2}{*}{ Q8 } & & "zinc"[Title/Abstract] OR "zinc"[MeSH Terms] & 141,754 \\
\hline & & $\begin{array}{l}\text { Q1 AND Q2 AND Q8 } \\
\text { After removing duplicates: } 7 \text { titles were added }\end{array}$ & 9 \\
\hline \multirow[t]{2}{*}{ Q9 } & & $\begin{array}{l}\text { "dietary selenium"[Title/Abstract] OR "selenium"[Title/Abstract] } \\
\text { OR "selenium"[MeSH Terms] }\end{array}$ & 34,348 \\
\hline & & $\begin{array}{l}\text { Q1 AND Q2 AND Q9 } \\
\text { After removing duplicates: } 0 \text { titles }\end{array}$ & 2 \\
\hline Q10 & & (Magnesium[Title/Abstract]) OR (Magnesium[MeSH Terms]) & 103,257 \\
\hline
\end{tabular}




\begin{tabular}{|c|c|c|}
\hline & Q1 AND Q2 AND Q10 & 1 \\
\hline \multirow[t]{2}{*}{ Q11 } & $\begin{array}{l}\text { "ascorbic acid"[Title/Abstract] OR "vitamin C"[Title/Abstract] OR } \\
\text { "ascorbic acid"[MeSH Terms] }\end{array}$ & 66,459 \\
\hline & $\begin{array}{l}\text { Q1 AND Q2 AND Q11 } \\
\text { After removing duplicates: } 0 \text { titles }\end{array}$ & 1 \\
\hline \multirow[t]{2}{*}{ Q12 } & $\begin{array}{l}\text { "thiamine"[Title/Abstract] OR "vitamin b1"[Title/Abstract] OR } \\
\text { "riboflavin"[Title/Abstract] OR "vitamin b2"[Title/Abstract] OR } \\
\text { "Vitamin B3"[Title/Abstract] OR "vitamin b5"[Title/Abstract] OR } \\
\text { "vitamin b6"[Title/Abstract] OR "Vitamin B12"[Title/Abstract] OR } \\
\text { "thiamine"[MeSH Terms] OR "riboflavin"[MeSH Terms] OR } \\
\text { "Niacinamide"[MeSH Terms] OR "Niacinamide"[Title/Abstract] OR } \\
\text { "Pantothenic Acid"[Title/Abstract] OR "Pantothenic Acid"[MeSH } \\
\text { Terms] OR "vitamin b 6"[MeSH Terms] OR "vitamin b 12"[MeSH } \\
\text { Terms] }\end{array}$ & 94,210 \\
\hline & $\begin{array}{l}\text { Q1 AND Q2 AND Q12 } \\
\text { After removing duplicates: } 3 \text { titles }\end{array}$ & 4 \\
\hline \multirow[t]{2}{*}{ Q13 } & $\begin{array}{l}\text { "alpha-Tocopherol"[Title/Abstract] OR "alpha-Tocopherol"[Text } \\
\text { Word] OR "alpha-Tocopherol"[MeSH Terms] OR "alpha- } \\
\text { Tocopherol"[Title/Abstract] OR "alpha-Tocopherol"[Text Word] } \\
\text { OR "vitamin e"[Title/Abstract] OR "vitamin e"[Text Word] }\end{array}$ & 47,673 \\
\hline & $\begin{array}{l}\text { Q1 AND Q2 AND Q13 } \\
\text { After removing duplicates: } 0 \text { titles }\end{array}$ & 2 \\
\hline \multirow[t]{2}{*}{ Q14 } & $\begin{array}{l}\text { "Thioctic acid"[Title/Abstract] OR "lipoic acid"[Title/Abstract] OR } \\
\text { "alpha lipoic acid"[Title/Abstract] OR "alpha lipoic } \\
\text { acid"[Title/Abstract] OR "Thioctic acid"[Text Word] OR "lipoic } \\
\text { acid"[Text Word] OR "alpha lipoic acid"[Text Word] OR "alpha } \\
\text { lipoic acid"[Text Word] OR "Thioctic acid"[MeSH Terms] }\end{array}$ & 6153 \\
\hline & $\begin{array}{l}\text { Q1 AND Q2 AND Q14 } \\
\text { After removing duplicates: } 0 \text { titles }\end{array}$ & 1 \\
\hline \multirow[t]{2}{*}{ Q15 } & $\begin{array}{l}\text { "Cysteine"[Title/Abstract] OR "Cysteine"[Text Word] OR } \\
\text { "Cysteine"[MeSH Terms] OR "L-Cysteine"[Title/Abstract] OR "L- } \\
\text { Cysteine"[Text Word] OR "half cysteine"[Text Word] OR "half } \\
\text { cysteine"[Title/Abstract] }\end{array}$ & 142,289 \\
\hline & $\begin{array}{l}\text { Q1 AND Q2 AND Q15 } \\
\text { After removing duplicates: } 3 \text { titles }\end{array}$ & 3 \\
\hline \multirow[t]{2}{*}{ Q16 } & $\begin{array}{l}\text { "epigallocatechin-3-O-gallate"[Title/Abstract] OR "epigallo- } \\
\text { catechin gallate"[Title/Abstract] OR "epigallocatechin-3- } \\
\text { gallate"[Title/Abstract] OR "epigallocatechin-3-O-gallate"[Text } \\
\text { Word] OR "epigallo-catechin gallate"[Text Word] OR } \\
\text { "epigallocatechin-3-gallate"[Text Word] OR "epigallocatechin } \\
\text { gallate"[Supplementary Concept] }\end{array}$ & 5604 \\
\hline & $\begin{array}{l}\text { Q1 AND Q2 AND Q16 } \\
\text { After removing duplicates: } \mathbf{1 7} \text { titles }\end{array}$ & 17 \\
\hline Q17 & $\begin{array}{l}\text { "curcumin*"[Title/Abstract] OR "curcuma"[Title/Abstract] OR } \\
\text { "turmeric"[Title/Abstract] OR "Diferuloylmethane"[Title/Abstract] } \\
\text { OR "curcumin*"[Text Word] OR "curcuma"[Text Word] OR } \\
\text { "turmeric"[Text Word] OR "Diferuloylmethane"[Text Word] OR } \\
\text { "curcuma"[MeSH Terms] OR "curcumin"[MeSH Terms] }\end{array}$ & 18,977 \\
\hline
\end{tabular}




\begin{tabular}{|c|c|c|}
\hline & $\begin{array}{l}\text { Q1 AND Q2 AND Q17 } \\
\text { After removing duplicates: } 4 \text { titles }\end{array}$ & 4 \\
\hline \multirow[t]{2}{*}{ Q18 } & $\begin{array}{l}\text { "Acetylcarnitine"[Title/Abstract] OR "Acetyl-L- } \\
\text { Carnitine"[Title/Abstract] OR "Acetylcarnitine"[Text Word] OR } \\
\text { "Acetyl-L-Carnitine"[Text Word] OR "Acetylcarnitine"[MeSH } \\
\text { Terms] }\end{array}$ & 2056 \\
\hline & $\begin{array}{l}\text { Q1 AND Q2 AND Q18 } \\
\text { After removing duplicates: } 1 \text { title }\end{array}$ & 2 \\
\hline \multirow[t]{2}{*}{ Q19 } & $\begin{array}{l}\text { "biotin"[Title/Abstract] OR "Vitamin B7"[Title/Abstract] OR } \\
\text { "Vitamin B 7"[Title/Abstract] OR "Vitamin H"[Title/Abstract] OR } \\
\text { "Coenzyme R"[Title/Abstract] OR "biotin"[Text Word] OR } \\
\text { "Vitamin B7"[Text Word] OR "Vitamin B 7"[Text Word] OR } \\
\text { "Vitamin H"[Text Word] OR "Coenzyme R"[Text Word] OR } \\
\text { "biotin"[MeSH Terms] }\end{array}$ & 33,640 \\
\hline & $\begin{array}{l}\text { Q1 AND Q2 AND Q19 } \\
\text { After removing duplicates: } 1 \text { title }\end{array}$ & 0 \\
\hline \multirow[t]{2}{*}{ Q20 } & $\begin{array}{l}\text { "choline"[Title/Abstract] OR "choline"[Text Word] OR } \\
\text { "choline"[MeSH Terms] }\end{array}$ & 81,632 \\
\hline & $\begin{array}{l}\text { Q1 AND Q2 AND Q20 } \\
\text { After removing duplicates: } 22 \text { titles }\end{array}$ & 26 \\
\hline \multirow[t]{2}{*}{ Q21 } & $\begin{array}{l}\text { "Lycopene"[Title/Abstract] OR "Lycopene"[Text Word] OR } \\
\text { "Lycopene"[MeSH Terms] }\end{array}$ & 5426 \\
\hline & Q1 AND Q2 AND Q21 & 0 \\
\hline
\end{tabular}

\section{Scopus search}

\begin{tabular}{|c|c|c|c|}
\hline Q1 & $\begin{array}{l}\text { Down } \\
\text { Syndrome }\end{array}$ & $\begin{array}{l}\text { ( TITLE-ABS-KEY ( "down syndrome" OR "down's } \\
\text { syndrome" OR "downs syndrome" OR "trisomy 21" )) AND ( } \\
\text { TITLE-ABS-KEY ( } \\
\text { infan* OR child* OR adolescen* OR teenager*)) }\end{array}$ & 22,762 \\
\hline Q2 & & $\begin{array}{l}\text { TITLE-ABS-KEY ( "dietary supplement*" OR "food } \\
\text { supplement*" OR "vitamin supplement*" OR "nutritional } \\
\text { supplement*" OR "antioxidant*" OR "antioxidant therapy" ) }\end{array}$ & 525,652 \\
\hline Q3 & & Q1 AND Q2 & 200 \\
\hline Q4 & & $\begin{array}{l}\text { TITLE-ABS-KEY ( health OR wellbeing OR "quality of } \\
\text { life" OR "cognitive function*" OR "cognitive } \\
\text { abil*" OR "cognitive perform*") }\end{array}$ & $5,334,652$ \\
\hline Q5 & & $\begin{array}{l}\text { Q3 AND Q4 (after pubyear 2004) } \\
\text { After removing duplicates Pubmed: } 34 \text { titles }\end{array}$ & 41 \\
\hline Q6 & & TITLE-ABS-KEY ( "oxidative stress" ) & 343,649 \\
\hline Q7 & & $\begin{array}{l}\text { Q3 AND Q7 (after pubyear 2004) } \\
49 \text { titels met Down in de titel } \\
\text { After removing duplicates Pubmed: } 38 \text { titles }\end{array}$ & 69 \\
\hline Q8 & & TITLE-ABS-KEY ( alzheimer* ) & 227,565 \\
\hline Q9 & & $\begin{array}{l}\text { Q3 AND Q8 (after pubyear 2004) } \\
\text { After removing duplicates Pubmed: } 1 \text { title }\end{array}$ & 13 \\
\hline
\end{tabular}




\begin{tabular}{|l|l|l|}
\hline Q10 & TITLE-ABS-KEY ( "immune system*" ) & 194,183 \\
\hline Q11 & $\begin{array}{l}\text { Q3 AND Q10 } \\
\text { After removing duplicates Pubmed: } 0 \text { titles }\end{array}$ & 2 \\
\hline
\end{tabular}




\section{Annex 5 Labels dietary supplements}




\section{MSB Neuro Plus 5th Generation}

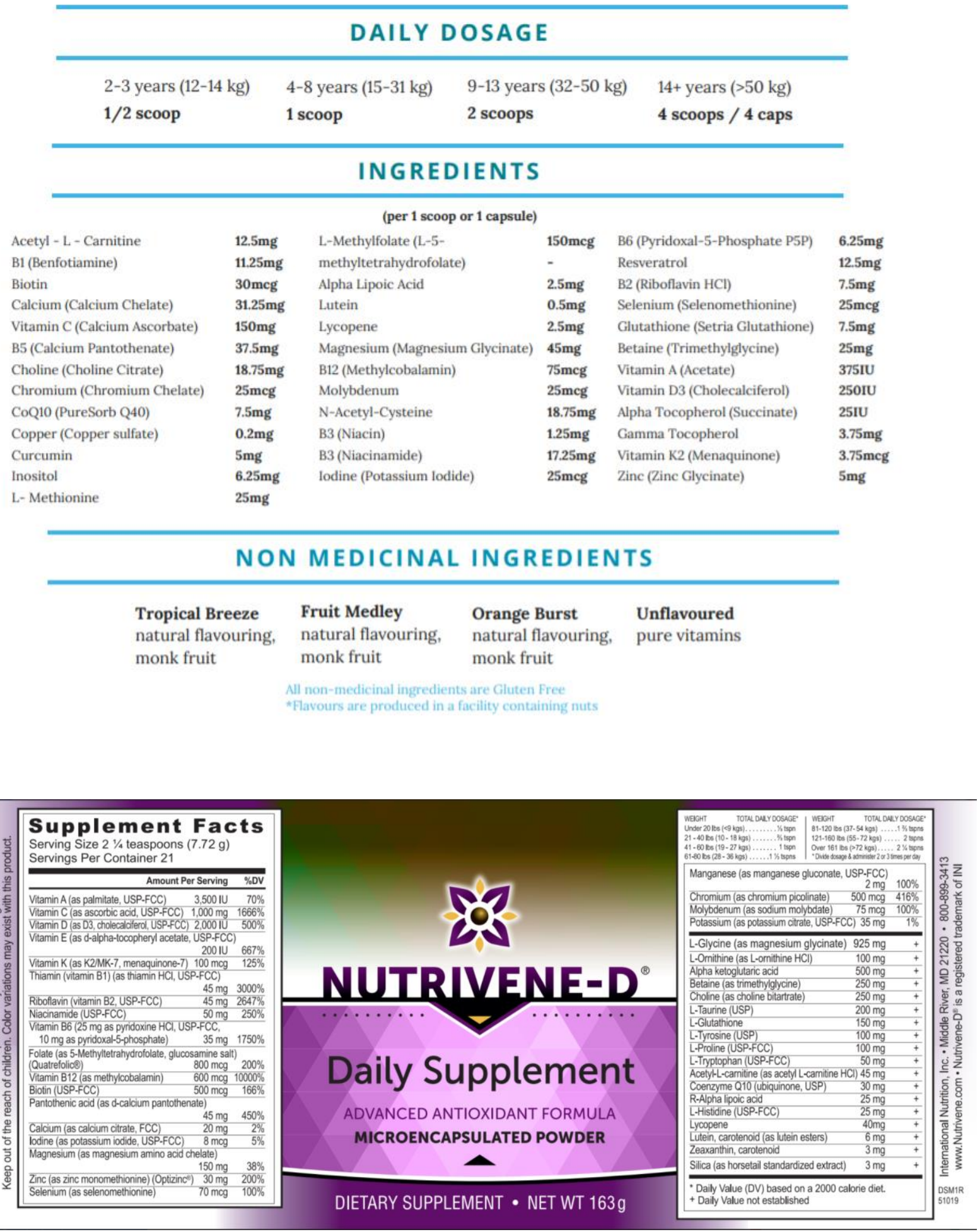






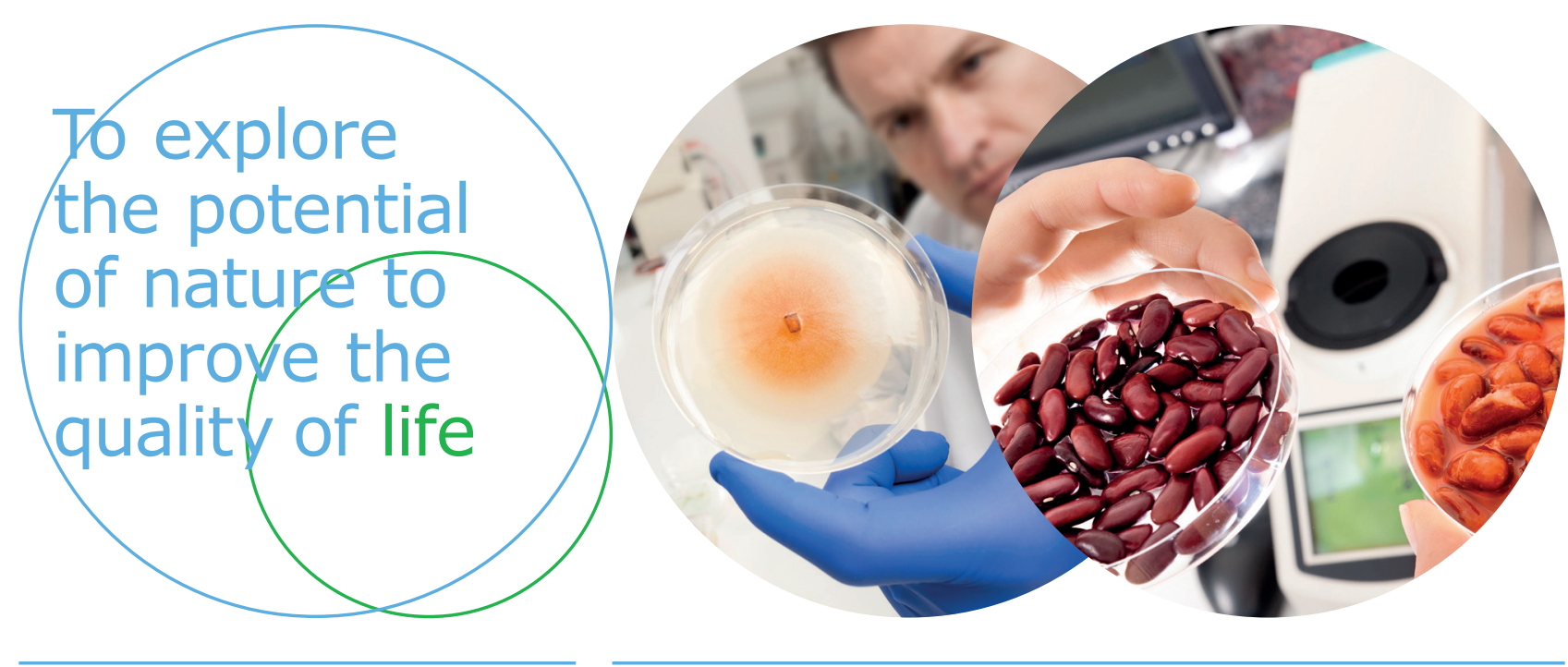

Wageningen Food \& Biobased Research Bornse Weilanden 9

6708 WG Wageningen

The Netherlands

www.wur.eu/wfbr

E info.wfbr@wur.nl

Report 376

ISBN 978-94-6395-005-3
The mission of Wageningen University \& Research is "To explore the potential of nature to improve the quality of life". Under the banner Wageningen University \& Research, Wageningen University and the specialised research institutes of the Wageningen Research Foundation have joined forces in contributing to finding solutions to important questions in the domain of healthy food and living environment. With its roughly 30 branches, 6,800 employees (6,000 fte) and 12,900 students, Wageningen University \& Research is one of the leading organisations in its domain. The unique Wageningen approach lies in its integrated approach to issues and the collaboration between different disciplines. 